\title{
Systematic study of triazolyl sterols for the development of new drugs against parasitic Neglected Tropical Diseases.
}

Exequiel O. J. Porta, ${ }^{a, \dagger}$ Shane Wilkinson, ${ }^{b}$ María Sol Ballari, ${ }^{a}$ Babu L. Tekwani ${ }^{c, \ddagger}$ and Guillermo R. Labadie. ${ }^{\text {be, }}$ *

a Instituto de Química Rosario (IQUIR-CONICET), Facultad de Ciencias Bioquímicas y Farmacéuticas, Universidad Nacional de Rosario. Suipacha 531, S2002LRK, Rosario, ARGENTINA

b. Queen Mary, University of London, Mile End Road, London E1 4NS, UK.

${ }^{c}$ National Center for Natural Products Research \& Department of Biomolecular Sciences, School of Pharmacy, University of Mississippi, MS 38677, USA.

d Departamento de Química Orgánica, Facultad de Ciencias Bioquímicas y Farmacéuticas, Universidad Nacional de Rosario, Suipacha 531, S2002LRK, Rosario, ARGENTINA.

* Corresponding author

${ }^{\dagger}$ Present address: Department of Chemistry, Durham University, DH1 3LE, UK.

‡ Present address: Department of Infectious Diseases, Division of Drug Discovery, Southern Research, Birmingham, AL 35205, USA. 


\begin{abstract}
A series of thirty 1,2,3-triazolylsterols were prepared by a stereocontrolled synthesis and inspired by azasterols with proven antiparasitic activity. Ten of these compounds constitute chimeras/hybrids of AZA and 1,2,3-triazolyl azasterols. The entire library was assayed against the etiological agents of the parasites responsible of kinetoplastid diseases ( $L$. donovani, T. cruzi and T. brucei). Several of the compounds were active at submicromolar/nanomolar concentration with excellent selectivity index, when compared to their activity in mammalian cells. Studies of the physicochemical properties in silico were conducted to rationalize the activities.
\end{abstract}

Keywords: Antiparasitic, azasterols, Click chemistry, NTDs, kinetoplastid diseases. 


\section{Introduction}

Neglected tropical diseases (NTDs) are a diverse group of infectious diseases that prevail in tropical and subtropical areas in 150 countries, and affect more than one billion people (15\% of the world's population) [1]. NTDs cost developing economies billions of dollars every year and are a significant source of morbidity and socioeconomic burden among the world's poorest countries [2]. Populations living in poverty, without adequate sanitation and in close contact with vectors and domestic animals and livestock are usually more affected.

These diseases represent a major endemic problem for global public health. They also impose a huge burden for both health and economy and, simultaneously, constitute a serious obstacle to achieving socioeconomic development and a good quality of life. In spite of this, these ailments receive little attention and are delayed in public health priorities [3]. During the last decade, diverse alliances between public and private sectors have turned their attention to these diseases, highlighting the fight to eradicate malaria [4].

The drugs available for the prophylaxis and treatment of these diseases are so far few in number, inadequate in terms of efficiency, often toxic and possess several undesirable side effects. In addition, vaccines against these diseases are not available on the market yet and the current treatments are usually expensive and difficult to administrate, whilst every year the reports of clinical cases containing multidrug-resistant parasites to conventional drugs are increased [5-7].

At this point, it is imperative and urgent to develop not only new and better forms of diagnosis and prophylaxis, but also to develop new chemotherapies [8].

To address the critical task of identifying New Chemical Entities (NCE) against NTDs, it is necessary to develop a series of strategies, including the proper selection of adequate molecular targets. This involves taking in consideration different characteristics including the essentiality, the drugability and the presence or absence of orthogonal proteins in the host [9].

Ergosterol biosynthesis has several molecular targets that are excellent candidates for developing campaigns to search for NCEs, for instance C14-Demethylase (target of action of triazole inhibitors) or C24-Sterolmethyltransferase (target of azasterols) among others [10].

Trypanosomatids have an essential requirement for specific endogenous C28 sterols. These sterols are necessary to maintain the structural and functional integrity of the membranes and in the cell cycle. On the other hand, they cannot use cholesterol (a C27 sterol) present in abundance in their vertebrate hosts (in contrast with Plasmodium which uses it) to meet these requirements, so they are very susceptible to the action of Ergosterol biosynthesis inhibitors (EBIs).

Ergosterol biosynthesis is considered a vital metabolic pathway in fungi and members of the Trypanosomatidae family. In these organisms, the route produces a special class of sterols, absent in mammalian host cells [11], that includes ergosterol and other C24-methylated sterols. Ergosterol 
is required for growth and viability, and differs structurally from cholesterol. Cholesterol contains only a single double bond in ring $\mathrm{B}$, is completely saturated in the side chain and does not contain a methyl group at C24. (Figure 1) Those differences are associated to divergent biosynthetic pathways that provides interesting target for drug development.

C24-Sterolmethyltransferase (24-SMT or SMT), also known as ERG6, catalyses the addition of a methyl group from AdoMet in the C24 side chain sterol in a key process for the biosynthesis of sterols in plants, fungi and parasites. This enzyme that has no counterpart or homologue in mammals, would constitute the limiting step in many of the biosynthetic pathways of the organisms where it is present. According to the TDR targets database, this enzyme is classified as highly druggable, so SMT is an ideal target for drug development [12].

Azasterols (Figure 1) are potent inhibitors of ergosterol biosynthesis, whose effects have been studied in T. cruzi, Leishmania spp. and T. brucei $[13,14]$, as well as in Candida spp. The antiparasitic and antifungal activity of those compounds are linked to the inhibition the 24-SMT. When the sterols side chain contains nitrogen atoms, mimics the postulated transition state for the enzyme mechanism of action [15], interrupting the ergosterol biosynthesis.

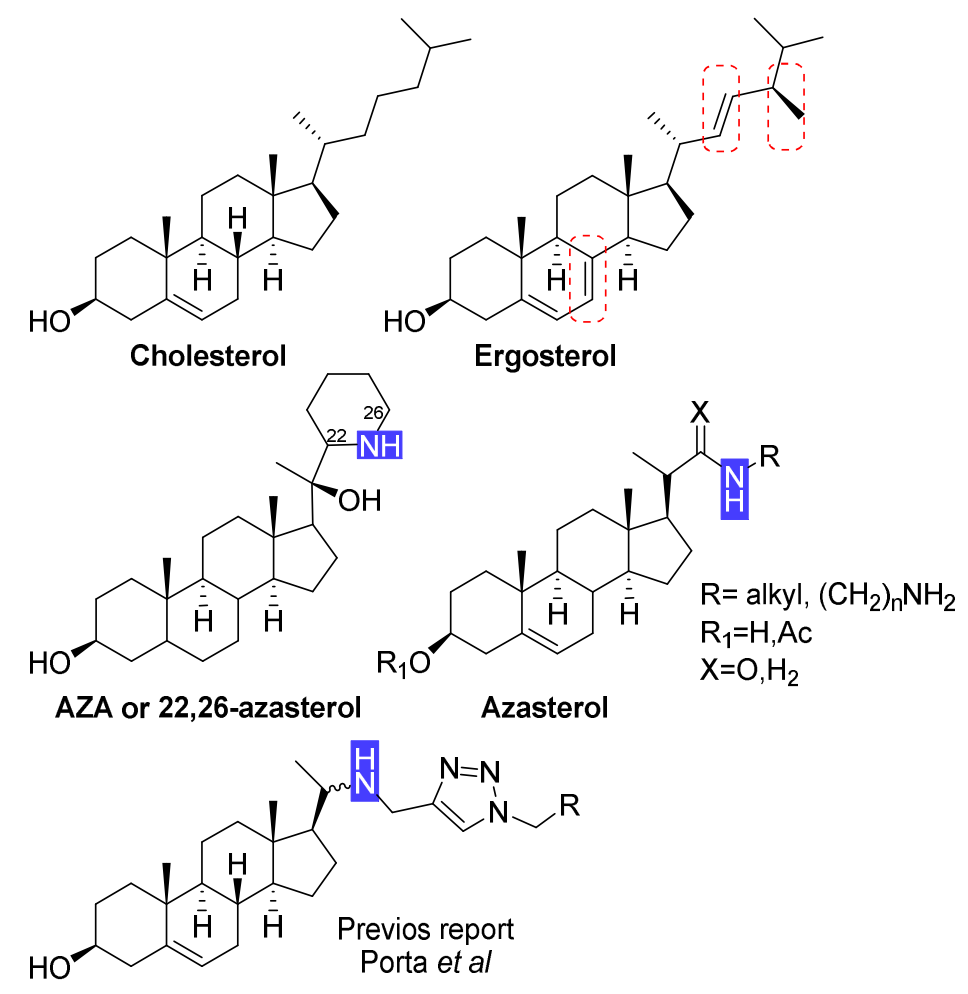

Figure 1. Top: Structural differences between cholesterol and ergosterol (marked in red box); Middle: Structures of AZA and Azasterols prepared with activity in the enzyme C24-Sterol methyl transferase; Bottom: Triazolyl sterols previously reported by our group [16].

Based on this background, we have previously reported a collection of triazolyl sterols (Figure 1) with activity in the low micromolar range against Leishmania donovani [16], one of the most dangerous etiological agents that causes the visceral form of leishmaniasis. In this opportunity we 
expanded the library exploring new functionalities. The collection was evaluated against TryTyrps to find NCEs with wide scope activity.

\section{Results and discussion}

\subsection{Library design}

Based on the models postulated by Nes [17,18] and Gilbert [19], we proposed some structural modifications of our first-generation library (Compounds A1 to B5, Table 1) preserving some critical features. First, the stereochemistry of the sterol ring, which is identical to ergosterol, was conserved. Second, the C3 hydroxy group that is essential for anchoring to the enzyme, was also preserved. Additionally, Gilbert and others $[15,19]$ have concluded that azaesteroids presenting C3 alcohol as acetate, in addition to a nitrogen in the side chain, displayed better activity on $T$. brucei rhodesiense. Those modifications increased the lipophilicity, facilitating the compounds to permeate the parasite membrane, and then they are intracellularly hydrolysed by esterases, to properly interact with the 24-SMT [15]. Accordingly, we decided to modify all the previously reported compounds, introducing an acetate on the $\mathrm{C} 3-\mathrm{OH}$ (Compounds $\mathrm{C} 1$ to D5, Table 1).

$\mathbf{E}$ and $\mathbf{F}$ series are chimeras built by combination of the first-generation library (Compounds A1 to B5) with 22,26-azasterol (AZA, Figure 1). AZA is one of the most studied azaterols as a Chagas disease and leishmaniasis drug candidate. It has been reported that $A Z A$ shows an interesting in vitro activity profile both in the epimastigote and intracellular amastigote form of $T$. cruzi, as well as in Leishmania spp. AZA probably acts by altering the composition of membrane sterols causing cell disruption [15]. In addition, the preparation and antiparasitic activity of related compounds have been reported showing levels of activities similar to AZA [14].

The design of $\mathbf{E}$ family was carried out conserving the amino alcohol scaffold in the sterol side chain with the correct configuration on carbon 20 , spatially separated by two carbon atoms. A linear spatial arrangement for the amine was adopted instead of a cyclic one. The point of diversity was focused on the decoration of the 1,2,3-triazole motif, replaced by hydrophobic groups.

The secondary amino group on the side chain is protonated at physiological pH [15]. This could emulate the proposed carbocation intermediate for the enzyme reaction mechanism. To verify the essentiality of the amino group, the F family (Compounds F1 to F5, Table 1) was prepared, inverting the triazole substitution.

\subsection{Synthesis}

Pregnenolone acetate (6) was prepared using pregnenolone and acetic anhydride in pyridine at room temperature, obtaining the expected product after 8 hours with a $98 \%$ yield (Scheme 1). 
In a second step, we functionalized the sterol with a terminal alkyne group and a secondary amine in the side chain by reductive amination previously optimized by our group [16] with $N$-propargylamine, in the presence of $4 \AA$ molecular sieves and sodium triacetoxyborohydride as the imine intermediate reducing agent. Using column chromatography, the two diastereoisomeric intermediates (Compounds $\mathbf{C}(R)-\mathbf{C} 20$ and $\mathbf{D}$ (S)-C20) were separated, in a 1:1 ratio with a 98\% yield. The assignment of the C20 stereochemistry was possible by comparison of the ${ }^{1} \mathrm{H}-\mathrm{NMR}$ and ${ }^{13} \mathrm{C}-\mathrm{NMR}$ signals between the new intermediaries generated and those prepared during the first generation library, which also have a crystallographic structure [16], evidencing that compounds B and D (S)C20 have the same configuration as ergosterol.

Ten triazoles were generated by 1,3-dipolar cycloadditions catalysed by $\mathrm{Cu}(\mathrm{I})$, using the same set of azides (1 to 5 ) that were used during the first-generation library, with an average yield of $83 \%$ (Compounds C1 to D5, Table 1). Our group has previously reported [20] that geranylazide exists in solution as a mixture of inseparable regioisomers, which after the cycloaddition stage allows to generate the $E$ and $Z$ isomers in a 3:2 ratio [21]. Although in some cases it is possible to separate the $E$ and $Z$ triazoles obtained from this azide mixture, in this case, due to the polarity of both diasteroisomers, all attempts to obtain pure isomers by chromatographic separation were unsuccessful.

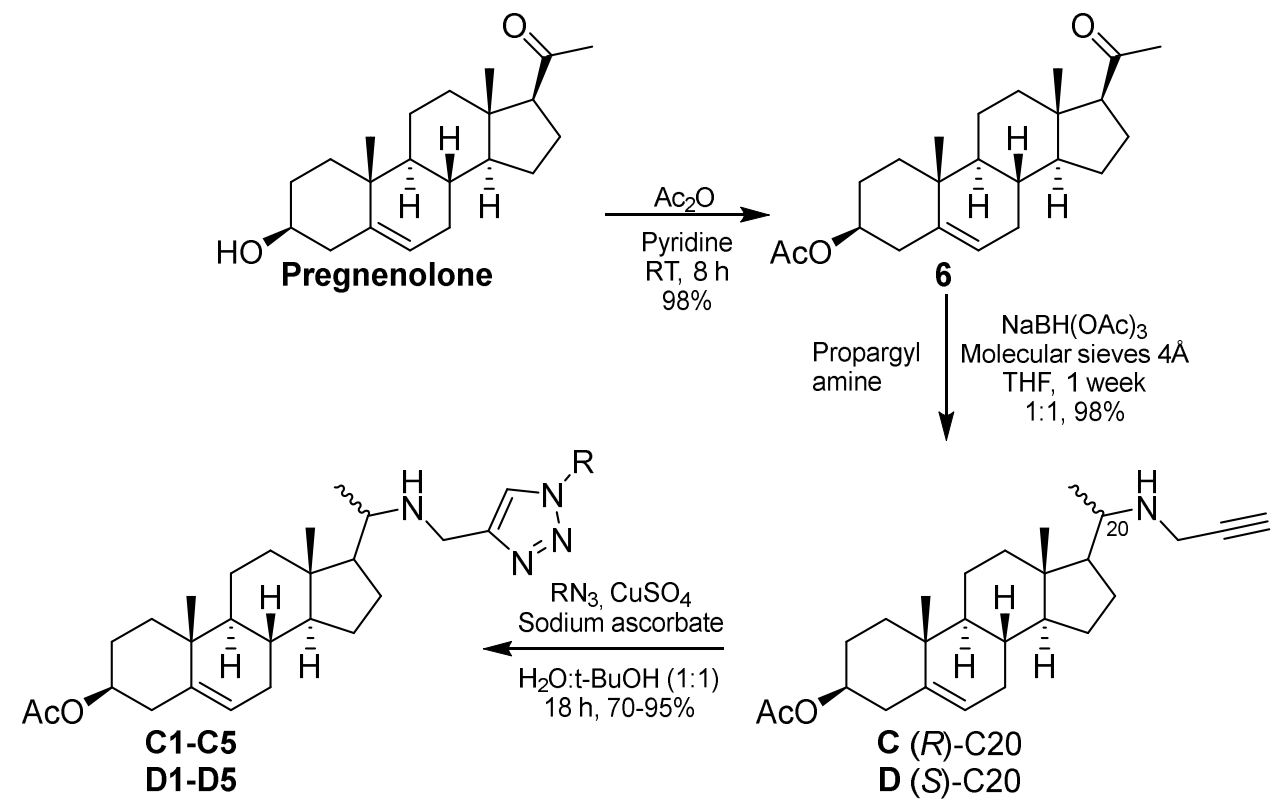

Scheme 1. Synthesis of libraries of $\mathbf{C}$ and $\mathbf{D}$ series.

For families $\mathbf{E}$ and $\mathbf{F}$, we used a divergent synthesis strategy from a common precursor (Scheme 2). Here, starting with pregnenolone once again, the C3-alcohol was protected as silyl ether using tertbutyldimethylsilyl chloride (TBDMS-Cl) in DMF and imidazole as the base. The expected product (7) was obtained after $12 \mathrm{~h}$ with a $93 \%$ yield. 
The next step of the synthesis involved the formation of an epoxide by homologation of the pregnenolone ketone through the Johnson-Corey-Chaykovsky reaction. The ilium was prepared using trimethylsulfoxonium iodide and sodium hydride, in DMSO at $0{ }^{\circ} \mathrm{C}$ for 2 hours. Subsequently, the protected ketosterol was added and the reaction mixture was left for a further 20 hours [22]. Under these conditions a single diastereoisomer $(8,20 \mathrm{R})$ was obtained with a $91 \%$ yield. The selectivity of this reaction in pregnenolone has already been reported previously [23], and is primarily due to the high reactivity of dimethylsulfonium methylide. This sulphur ilium reacts quickly only on the sterically less hindered side of the ketone. The epoxide configuration was confirmed by comparison of the ${ }^{1} \mathrm{H}$ NMR spectrum signals of the two oxirane protons and to structures previously reported in the literature $[23,24]$.

This epoxide 8 constitutes a valuable intermediary in our strategy, since it is possible to open it with a wide variety of nucleophilic or acid reagents, thus being an alternative for generating molecular diversity in future libraries.

The epoxide opening [25] was performed separately with $\mathrm{NaN}_{3}$, and with $\mathrm{N}$ propargylamine, in the presence of the $\mathrm{LiClO}_{4}$ salt and in acetonitrile at reflux for 5 days, in both cases allowing the alkylsterol 9 with $87 \%$ yield and intermediate azide 10 with $70 \%$ yield.

Once these intermediaries were obtained, in this case, the alcohol was deprotected before the formation of the triazoles. Using standard conditions, tetrabutylammonium fluoride (TBAF) in THF, for 12 hours, at room temperature alkynylsterol $\mathbf{E}$ and azidosterol $\mathbf{F}$ were obtained in 90 and $87 \%$, respectively.

Finally, 5 triazoles were obtained after the CuAAC between $\mathbf{E}$ and the corresponding set of azides, with an average yield of $81 \%$ (E1 to E5, Table 1).

For intermediate azide F, five commercial terminal alkynes stereoelectronically similar to the azide set were selected. In this case the final five products were obtained with an average yield of $83 \%$ after the cycloaddition step (F1 to F5, Table 1). 
<smiles>CC(=O)C1CCC2C3CC=C4C[C@@H](O)CCC4(C)[C@H]3CC[C@]12C</smiles>

Pregnenolone
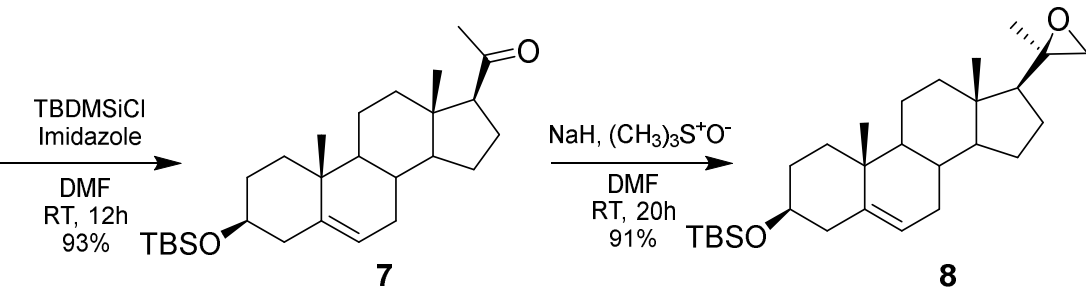

Propargylamine, $\mathrm{LiClO}_{4}$

$\mathrm{CH}_{3} \mathrm{CN}$ Reflux

5 days, $87 \%$

$\mathrm{NaN}_{3}, \mathrm{LiClO}_{4} \downarrow \begin{gathered}\mathrm{CH}_{3} \mathrm{CN} \text { Reflux } \\ 5 \text { days, } 70 \%\end{gathered}$
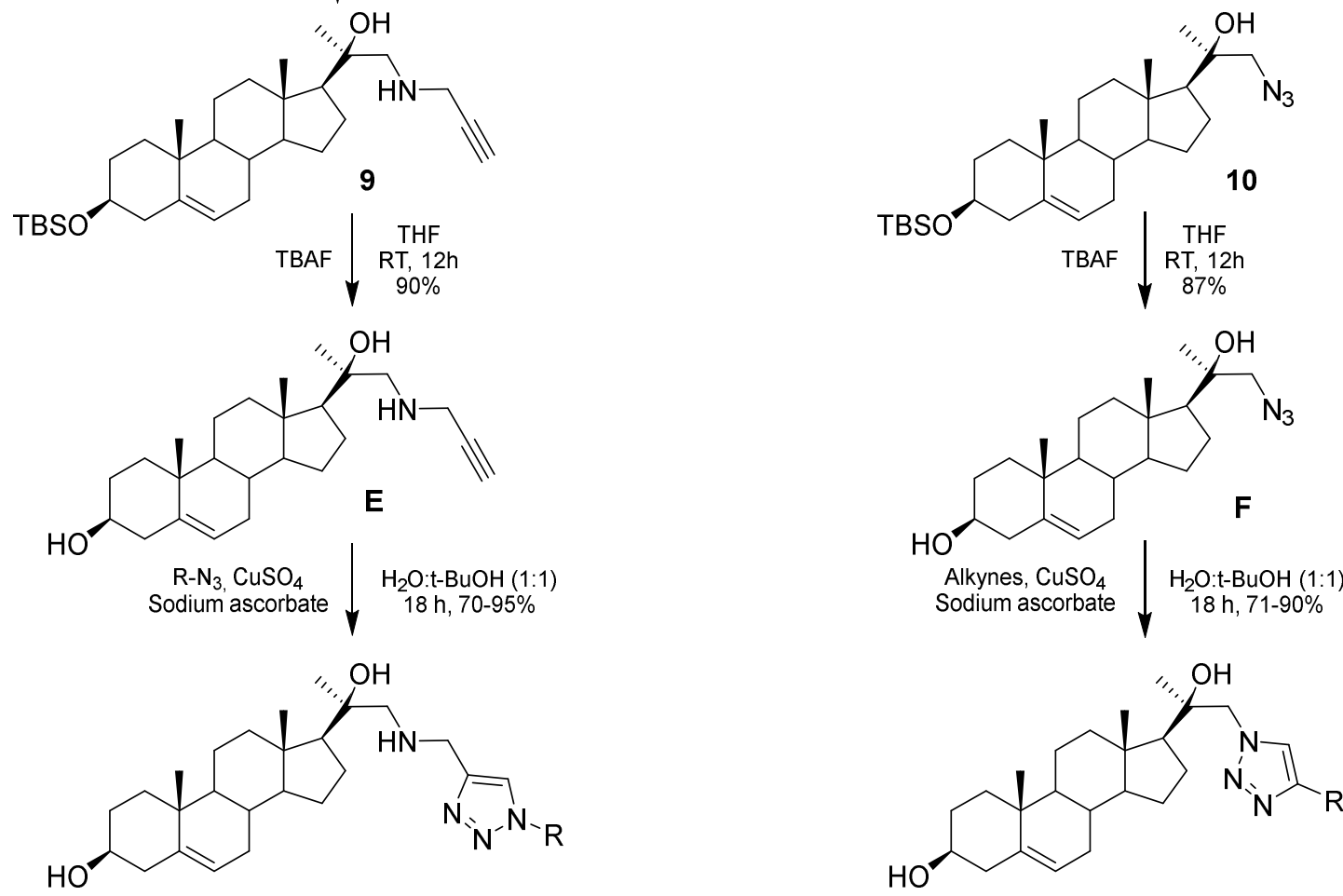

E1-E5

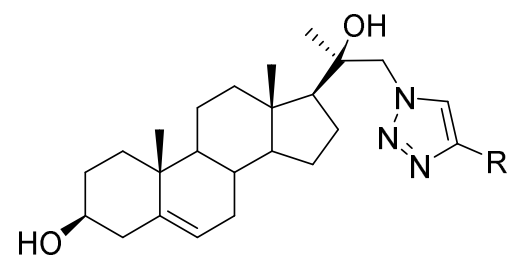

F1-F5

Scheme 2. Synthesis of libraries of $\mathbf{E}$ and $\mathbf{F}$ series. 
Table 1. 1,2,3-triazolyl sterols synthesized in this work.

\begin{tabular}{|c|c|c|c|c|c|c|c|}
\hline & Series & & & & Series F & & \\
\hline Series & Cmpd & $\mathrm{R}^{1}$ & $X$ & $\mathrm{Y}$ & $\mathrm{R}^{2}$ & (C20) & Yield (\%) \\
\hline \multirow{5}{*}{ A } & A1 & $\mathrm{H}$ & $\mathrm{H}$ & $\mathrm{NH}$ & $\mathrm{Bn}$ & $R$ & 89 \\
\hline & A2 & $\mathrm{H}$ & $\mathrm{H}$ & $\mathrm{NH}$ & $\mathrm{CH}_{2} \mathrm{COOEt}$ & $R$ & 78 \\
\hline & A3 & $\mathrm{H}$ & $\mathrm{H}$ & $\mathrm{NH}$ & Octyl & $R$ & 83 \\
\hline & A4 & $\mathrm{H}$ & $\mathrm{H}$ & $\mathrm{NH}$ & Geranyl & $R$ & 90 \\
\hline & A5 & $\mathrm{H}$ & $\mathrm{H}$ & $\mathrm{NH}$ & $\mathrm{Ph}\left(\mathrm{CH}_{2}\right)_{3}$ & $R$ & 94 \\
\hline \multirow{5}{*}{ B } & B1 & $\mathrm{H}$ & $\mathrm{H}$ & $\mathrm{NH}$ & $\mathrm{Bn}$ & $S$ & 76 \\
\hline & B2 & $\mathrm{H}$ & $\mathrm{H}$ & $\mathrm{NH}$ & $\mathrm{CH}_{2} \mathrm{COOEt}$ & $S$ & 78 \\
\hline & B3 & $\mathrm{H}$ & $\mathrm{H}$ & $\mathrm{NH}$ & Octyl & $S$ & 75 \\
\hline & B4 & $\mathrm{H}$ & $\mathrm{H}$ & $\mathrm{NH}$ & Geranyl & $S$ & 94 \\
\hline & B5 & $\mathrm{H}$ & $\mathrm{H}$ & $\mathrm{NH}$ & $\mathrm{Ph}\left(\mathrm{CH}_{2}\right)_{3}$ & $S$ & 90 \\
\hline \multirow{5}{*}{ C } & C1 & $A c$ & $\mathrm{H}$ & $\mathrm{NH}$ & $\mathrm{Bn}$ & $R$ & 90 \\
\hline & C2 & $A c$ & $\mathrm{H}$ & $\mathrm{NH}$ & $\mathrm{CH}_{2} \mathrm{COOEt}$ & $R$ & 86 \\
\hline & C3 & $A c$ & $\mathrm{H}$ & $\mathrm{NH}$ & Octyl & $R$ & 76 \\
\hline & C4 & Ac & $\mathrm{H}$ & $\mathrm{NH}$ & Geranyl & $R$ & 80 \\
\hline & C5 & Ac & $\mathrm{H}$ & $\mathrm{NH}$ & $\mathrm{Ph}\left(\mathrm{CH}_{2}\right)_{3}$ & $R$ & 85 \\
\hline \multirow{5}{*}{ D } & D1 & Ac & $\mathrm{H}$ & $\mathrm{NH}$ & $\mathrm{Bn}$ & $S$ & 83 \\
\hline & D2 & Ac & $\mathrm{H}$ & $\mathrm{NH}$ & $\mathrm{CH}_{2} \mathrm{COOEt}$ & $S$ & 70 \\
\hline & D3 & Ac & $\mathrm{H}$ & $\mathrm{NH}$ & Octyl & $S$ & 81 \\
\hline & D4 & Ac & $\mathrm{H}$ & $\mathrm{NH}$ & Geranyl & $S$ & 88 \\
\hline & D5 & Ac & $\mathrm{H}$ & $\mathrm{NH}$ & $\mathrm{Ph}\left(\mathrm{CH}_{2}\right)_{3}$ & $S$ & 95 \\
\hline \multirow{5}{*}{ E } & E1 & $\mathrm{H}$ & $\mathrm{OH}$ & $\mathrm{CH}_{2} \mathrm{NH}$ & $\mathrm{Bn}$ & $R$ & 79 \\
\hline & E2 & $\mathrm{H}$ & $\mathrm{OH}$ & $\mathrm{CH}_{2} \mathrm{NH}$ & $\mathrm{CH}_{2} \mathrm{COOEt}$ & $R$ & 90 \\
\hline & E3 & $\mathrm{H}$ & $\mathrm{OH}$ & $\mathrm{CH}_{2} \mathrm{NH}$ & Octyl & $R$ & 85 \\
\hline & E4 & $\mathrm{H}$ & $\mathrm{OH}$ & $\mathrm{CH}_{2} \mathrm{NH}$ & Geranyl & $R$ & 81 \\
\hline & E5 & $\mathrm{H}$ & $\mathrm{OH}$ & $\mathrm{CH}_{2} \mathrm{NH}$ & $\mathrm{Ph}\left(\mathrm{CH}_{2}\right)_{3}$ & $R$ & 71 \\
\hline \multirow{5}{*}{$\mathbf{F}$} & F1 & $\mathrm{H}$ & $\mathrm{OH}$ & $\mathrm{CH}_{2}$ & $\mathrm{Ph}$ & $R$ & 69 \\
\hline & F2 & $\mathrm{H}$ & $\mathrm{OH}$ & $\mathrm{CH}_{2}$ & COOMe & $R$ & 73 \\
\hline & F3 & $\mathrm{H}$ & $\mathrm{OH}$ & $\mathrm{CH}_{2}$ & Pentyl & $R$ & 86 \\
\hline & F4 & $\mathrm{H}$ & $\mathrm{OH}$ & $\mathrm{CH}_{2}$ & $\mathrm{CH}_{2} \mathrm{CH}_{2} \mathrm{OH}$ & $R$ & 97 \\
\hline & F5 & $\mathrm{H}$ & $\mathrm{OH}$ & $\mathrm{CH}_{2}$ & $\mathrm{Ph}\left(\mathrm{CH}_{2}\right)_{3}$ & $R$ & 92 \\
\hline
\end{tabular}

\subsection{Biological activity}

The in vitro antiparasitic activity of the entire collection of 30 compounds and its intermediates was assessed (Table 2). The activity as antileishmanial agents was carried out on $L$. donovani promastigotes, the main etiological agent of the visceral variant. Activity against $T$. cruzi, the $I_{50}$ was tested on the epimastigote form. The possible action against Trypanosoma brucei, the African protozoan that causes sleeping sickness disease or Human African Trypanosomiasis (HAT), was finally evaluated. In addition, the $\mathrm{IC}_{50}$ values of commercial drugs for each disease were determined, as a positive control using pentamidine and amphotericin B for leishmaniasis, benzdidazol and nifurtimox against Chagas disease, and melarsoprol against HAT. DMSO was used as a negative control. Finally, cytotoxicity was evaluated in African green monkey kidney epithelial cell line (VERO). 
Table 2. Antiparasitic and cytotoxicity activities of our entire library.

\begin{tabular}{|c|c|c|c|c|c|c|c|}
\hline \multirow[t]{2}{*}{ Comp } & \multicolumn{2}{|c|}{$\begin{array}{c}\text { L. donovani } \\
\text { promastigotes }\end{array}$} & \multicolumn{2}{|c|}{$\begin{array}{c}\text { T. brucei } \\
\text { bloodstream form }\end{array}$} & \multicolumn{2}{|c|}{$\begin{array}{c}T . \text { cruzi } \\
\text { epimastigotes }\end{array}$} & \multirow{2}{*}{$\begin{array}{l}\text { Cytotoxicity } \\
\text { VERO cells }\end{array}$} \\
\hline & $\mathrm{IC}_{50}$ & S.I. & $I_{50}$ & S.I. & $I_{50}$ & S.I. & \\
\hline A & $>10$ & ND & $>10$ & ND & 2.03 & $>6.57$ & $>13.35$ \\
\hline A1 & 6.14 & $>1.67$ & 1.77 & $>5.78$ & 2.47 & $>4.14$ & $>10.23$ \\
\hline A2 & 6.60 & $>1.56$ & 6.50 & $>1.59$ & $>10$ & ND & $>10.32$ \\
\hline A3 & 2.55 & $>3.85$ & 1.50 & $>6.53$ & $>10$ & ND & $>9.79$ \\
\hline A4 & 1.14 & $>8.20$ & 0.66 & $>14.16$ & $>10$ & ND & $>9.35$ \\
\hline A5 & 1.94 & $>5.00$ & 1.82 & $>5.18$ & 6.48 & $>1.45$ & $>9.42$ \\
\hline B & 4.50 & $>2.98$ & $>10$ & ND & 1.27 & $>10.51$ & $>13.35$ \\
\hline B1 & 1.33 & $>7.69$ & 0.68 & $>15.05$ & 0.33 & $>31.00$ & $>10.23$ \\
\hline B2 & 6.40 & $>1.61$ & $>10$ & ND & $>10$ & ND & $>10.32$ \\
\hline B3 & 1.47 & $>6.67$ & 0.55 & $>17.80$ & 1.95 & $>5.02$ & $>9.79$ \\
\hline B4 & 1.68 & $>5.56$ & 0.64 & $>14.61$ & 3.17 & $>2.95$ & $>9.35$ \\
\hline B5 & 1.35 & $>7.14$ & 1.43 & $>6.77$ & 2.22 & $>4.36$ & $>9.68$ \\
\hline C & $>10$ & ND & 5.03 & $>2.30$ & $>10$ & ND & $>11.94$ \\
\hline C1 & 9.34 & $>0.77$ & 1.15 & $>6.22$ & $>10$ & ND & $>7.16$ \\
\hline $\mathrm{C} 2$ & 6.08 & $>1.56$ & 6.50 & $>1.46$ & $>10$ & ND & $>9.49$ \\
\hline C3 & $>10$ & ND & 1.98 & $>4.57$ & $>10$ & ND & $>9.04$ \\
\hline C4 & 10.00 & $>0.84$ & 1.25 & $>6.93$ & $>10$ & ND & $>8.67$ \\
\hline C5 & $>10$ & ND & 0.20 & $>44.74$ & 4.50 & $>1.99$ & $>8.95$ \\
\hline D & $>10$ & ND & 1.80 & $>6.44$ & 8.88 & $>1.31$ & $>11.94$ \\
\hline D1 & 2.54 & $>3.70$ & 0.20 & $>47.10$ & 2.55 & $>3.69$ & $>9.42$ \\
\hline D2 & 4.90 & $>1.94$ & 0.66 & $>14.38$ & 7.80 & $>1.22$ & $>9.49$ \\
\hline D3 & 7.87 & $>1.15$ & 0.62 & $>14.59$ & $>10$ & ND & $>9.04$ \\
\hline D4 & 4.83 & $>1.79$ & 0.63 & $>13.76$ & $>10$ & ND & $>8.67$ \\
\hline D5 & 2.99 & $>2.99$ & 0.20 & $>44.74$ & 6.30 & $>1.42$ & $>8.95$ \\
\hline$E$ & $>10$ & ND & 1.77 & $>6.95$ & $>10$ & ND & $>12.31$ \\
\hline E1 & 1.95 & $>4.95$ & 0.12 & $>80.32$ & 8.28 & $>1.16$ & $>9.64$ \\
\hline E2 & $>10$ & ND & $>10$ & ND & $>10$ & ND & $>9.71$ \\
\hline E3 & 1.46 & $>6.33$ & 0.63 & $>14.67$ & 8.13 & $>1.14$ & $>9.24$ \\
\hline E4 & 0.78 & $>11.36$ & 0.65 & $>13.62$ & 9.00 & $>0.98$ & $>8.85$ \\
\hline E5 & 1.04 & $>8.77$ & $>10$ & ND & $>10$ & ND & $>9.14$ \\
\hline $\mathbf{F}$ & $>10$ & ND & $>10$ & ND & $>10$ & ND & $>11.98$ \\
\hline F1 & $>10$ & ND & $>10$ & ND & $>10$ & ND & $>10.51$ \\
\hline F2 & $>10$ & ND & 8.28 & $>1.28$ & $>10$ & ND & $>10.60$ \\
\hline F3 & $>10$ & ND & 0.18 & $>59.80$ & 6.33 & $>1.68$ & $>10.64$ \\
\hline F4 & $>10$ & ND & 1.78 & $>6.33$ & $>10$ & ND & $>11.27$ \\
\hline F5 & $>10$ & ND & 2.27 & $>4.25$ & $>10$ & ND & $>9.66$ \\
\hline Pent & 6.17 & & & & & & \\
\hline AmpB & 0.35 & & & & & & \\
\hline Mel & & & 0.01 & & & & \\
\hline Ben & & & & & 7.4 & & \\
\hline Nif & & & & & 7.7 & & \\
\hline
\end{tabular}

All IC 50 values are expressed in $\mu \mathrm{M}$. SI (selectivity index) $=I \mathrm{I}_{50}$ vero $/ \mathrm{IC}_{50}$ parasite. Pent: pentamidine, AmpB: amphotericine B, Mel: melarsoprol, Ben: Benznidazol, and Nif: Nifurtimox. ND: not determined. 


\subsubsection{Antileishmanial activity}

All the analogues and intermediates were assayed against $L$. donovani. To our satisfaction, most of the compounds were active against this parasite (Table 2). Eighty percent of the collection has an $\mathrm{IC}_{50}$ below $10 \mu \mathrm{M}$, with $56 \%$ of the library being more potent than pentamidine, one of the reference drugs against leishmaniasis. Compound E4 $\left(\mathrm{IC}_{50}=780 \mathrm{nM}, \mathrm{SI}>11.36\right)$ is the best in the collection, with an activity in the same order as Amphotericin B (780 nM vs $350 \mathrm{nM}$, respectively) and more than 8 times more potent than pentamidine.

When the activities in $L$. donovani were compared among all the prepared families, the need to position an amine functionality in the sterol side chain emerges as the first major conclusion. When this group is not present, a significant decrease in their potency was observed (compounds of the F family).

Analogs with (S)-C20 configuration on the sterol side chain are significantly more active than the $(R)$-C20. This behaviour is observed especially when they are compared between the acetylated families (C family - average $\mathrm{IC}_{50}>8.47 \mu \mathrm{M}$, D family - average $\mathrm{IC}_{50}=4.26 \mu \mathrm{M}$ ).

Likewise, the presence of an acetyl group on the C3 (sterol ring A) decreases the activity between two and three times on average compared to the compounds without the acete group in C3 alcohol (A family - average $\mathrm{IC}_{50}=3.67 \mu \mathrm{M}$; B family - average $\mathrm{IC}_{50}=2.44 \mu \mathrm{M}$ ). Furthermore, analogs with more voluminous and hydrophobic substituents on the triazole tends to be more potent.

Activity of our chimeric compounds (E family, Table 1 ) is remarkable, with the exception of E2. Average $\mathrm{IC}_{50}$ of the active compounds of this family is $1.30 \mu \mathrm{M}$. That is, almost 5 times more active than pentamidine and only 3.5 times less active than amphotericin $\mathrm{B}$.

Finally, it has been postulated that azasterols can mimic the carbocation mechanistic intermediate and Gilbert's group has explored that hypothesis preparing compounds containing nitrogen on the sterol lateral chain. These compounds showed an enzyme inhibition profile well correlated with their antiparasitic activity, validating sterol methyltransferase as a druggable target. $L$. donovani promastigotes were inhibited by $A Z A$ with an $I_{50}$ of $12 \mu \mathrm{M}$ [15]. Therefore, the success in the construction of the chimera family between our reported library and AZA is emphatically highlighted, where the total activity of those analogues is higher than the compounds from which they were inspired. Making these chimeric compounds excellent starting points for optimization and the development for new antileishmanial leads.

\subsubsection{Biological activity in $T$. brucei}

Looking for active compounds against the etiological agent of African trypanosomiasis, the library was tested in vitro against $T$. brucei (Table 2). In this case, the best performances have been obtained compared to the activities in the other organisms. More than $86 \%$ of the compounds in 
our collection were active against this parasite at concentrations lower than $10 \mu \mathrm{M}$. Even half of this library was active in T. brucei at submicromolar levels. Although none of the compounds have activities on the order of Melarsoprol (10 nM), the activities on T. brucei are very promising, especially considering that this commercial drug is an arsenic derivative that not only has numerous side effects, but also very high mortality rates.

The best compound in the entire library is the chimeric $\mathrm{E} 1\left(\mathrm{IC}_{50}=120 \mathrm{nM}, \mathrm{SI}>80.32\right)$. However, there are other four compounds with activities between 180 to $200 \mathrm{nM}$ (compounds C5, D1, D5, F3). All of them (with the exception of F3), containing aromatic substituents on the 1,2,3-.triazol. Analysed by families, the compounds of family $\mathbf{D}$ are the most active (from $200 \mathrm{nM}$ to $660 \mathrm{nM}$ ). In this family, compared to the other substituents, the presence of aromatic ring increases the activity more than 3 times.

The stereochemistry at the C20 carbon is relevant. Compounds with stereochemistry analogous to zymosterol (Family $\mathbf{B}$ and $\mathbf{D}$ ) are more active than their (R)-C20 analogues (Families $\mathbf{A}$ and $\mathbf{C}$ ). On the other hand, the presence of acetate groups is important to improve the activity of the molecules against this parasite. As previously stated, these results were expected and are in accordance with those reported by Gilbert's grooup and others [15,19], where an improvement in the activity levels of compounds was obtained with the C3 alcohol protected as acetate ester. Moreover, these results are clearly evidenced in the activities of the synthetic intermediaries of the first 4 families (Compounds $\mathbf{A}$ to $\mathbf{D}$ ).

The chimeric compounds of the $\mathbf{E}$ family and their synthetic intermediate $(\mathbf{E})$ have excellent antiT. brucei activities, with the exception of compounds E2 and E5, which were inactive at concentrations less than $10 \mu \mathrm{M}$. Among them, compound E1 stands out, because it is the most active member of the complete collection. In the future we will continue working over this family, exploring other alternatives (protection of secondary alcohol in C3 as acetate ester, etc.) in order to increase the activities of these hits.

Interestingly, the members of the $\mathbf{F}$ family also showed good activity values against $T$. brucei, but not better than those obtained by the other families of compounds, allowing us to conclude that the presence of a secondary amine group in the side chain of the molecule increases the activity of this scaffold. However, there is an interesting exception, compound $\mathbf{F 3}$, which is also one of the most active against this parasite (180 nM, SI> 59.80).

\subsubsection{Biological activity in $T$. cruzi}

Finally, all the compounds and their intermediaries were tested in vitro against $T$. cruzi, the protozoan parasite that causes Chagas' disease in American continent (Table 2). In this case, 47\% of compounds showed an activity below $10 \mu \mathrm{M}$. Surprisingly, more than $30 \%$ of the tested analogues had better activities than the two commercial control drugs (Nifurtimox and Benznidazole). The most promising member is $\mathbf{B} 1\left(\mathrm{IC}_{50}=330 \mathrm{nM}, \mathrm{SI}>31.00\right)$, a structure 24 times 
more active than Nifurtimox and 22 times more active than Benznidazole, and the only one in the entire library in the submicromolar order.

Stereochemistry at C20 governs activity in T. cruzi. It is clearly observed that compounds with the $(S)$ - configuration (7 actives out of 10) are significantly more active than those with the $(R)$ configuration (only 3 actives out of 10 ). Contrary to what happens with $T$. brucei, in this case derivatizing the $\mathrm{C} 3$ alcohol results in a decrease in the activity on $T$. cruzi. This fact is very interesting, since a small modification on this part of the molecule can modulate the activity of our compounds towards the African or American variant of trypanosomiasis. It is noteworthy that the intermediates $\mathbf{A}\left(\mathrm{IC}_{50}=2.03 \mu \mathrm{M}, \mathrm{SI}>6.57\right)$ and $\mathbf{B}\left(\mathrm{IC}_{50}=1.27 \mu \mathrm{M}, \mathrm{SI}>10.51\right)$ are two of the molecules with the best activity profiles against this protozoan. Both intermediates with terminal alkynes can become excellent probes to study both the mechanisms of action of these compounds on parasites and to carry out activity-based protein profiling (ABPP) studies.

The chimera families $\mathbf{E}$ and $\mathbf{F}$ do not substantially improve the activity compared to the first two generations of triazolyl sterols (families $\mathbf{A}$ to $\mathbf{D}$ ), but it does allow us to conclude that the presence of a basic nitrogen atom on the side chain of the sterol is important to achieve active structures in T. cruzi.

\subsubsection{Cytotoxicity}

Our library was tested for their effect on Vero cells to a maximum concentration of $4.75 \mu \mathrm{g} / \mathrm{mL}$ (between 8 and $11 \mu \mathrm{M}$ ). This cell line is an excellent model for test cytotoxicity in vitro because it is an aneuploid and a continuous cell linage. None of the compounds showed cytotoxicity at levels lower than those tested. This allows several compounds to have excellent selectivity index values towards parasites (Table 2).

\subsection{In silico physicochemical parameters}

Due to the nature of the diseases faced, the design of robust structures with physicochemical parameters that allow the crossing of various biological membranes (such as blood-brain barrier for African trypanosomiasis) is essential. Likewise, it is desirable to work with compounds that can potentially be administered orally. For this reason, control of physicochemical properties during compounds design and subsequent optimization is crucial to identify the scaffold with good drug qualities. Addressing pharmacokinetic properties in the early stages of drug development reduces the chances of failure in clinical trials and also helps to reduce the time during the process to optimize the safety issues of compounds.

In silico physicochemical profile of our analogues were conducted by computational studies to predict their adsorption, distribution, metabolism and excretion properties (ADME), Lipinski's rule of five, the potential risks of toxicity, and to rationalize the biological activities found based on the structural modifications made. 
Physicochemical parameters relevant for drug-target interaction, oral bioavailability and ADMETox in general, were calculated using Osiris DataWarrior [26], ChemAxon [27], SwissADME [28] and pkCSM [29] online platforms. Among the calculated properties we included size (molecular weight, total surface area), polar interactions (polar surface area, number of $\mathrm{H}$-bond donors and acceptors), lipophilicity ( $\log \mathrm{P}, \log \mathrm{D})$, water solubility (logS), pharmacokinetics, toxicity and druglikeness. The most relevant physicochemical parameters for the library are represented in histograms in Figure 2, full data can be found in the Supporting Information. Considering that our library is focused, we could reach a proper physicochemical properties distribution, with maximum count values at $\log \mathrm{D}=5-6, \mathrm{cLogS}=-6-(-5.5), 2 \mathrm{H}$-bond donors, $6 \mathrm{H}$-bond acceptors, $\mathrm{MW}=$ $520-540 \mathrm{Da}$, total surface area $=400-420 \AA^{2}$, and polar surface area $=60-70 \AA^{2}$.
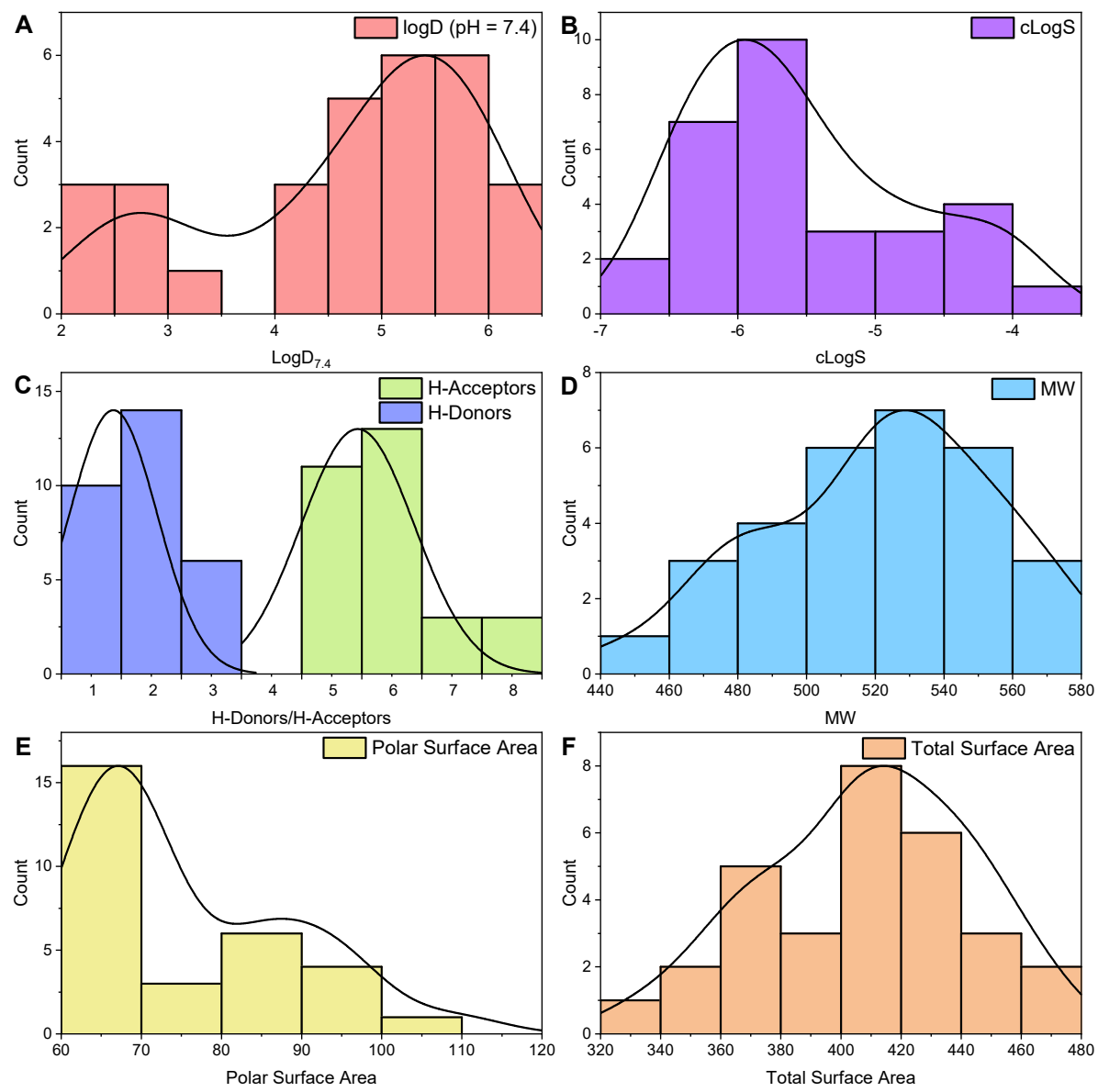

Figure 2. Physicochemical properties distribution for triazolyl sterols analogs. Distributions were fitted to Kernel Smooth function. A) LogD ( $\mathrm{pH}=7.4$ ); B) cLogS; C) Hydrogen bond donors and acceptors; D) MW; E) Polar Surface Area; F) Total Surface Area.

The predicted ADME-Tox properties were evaluated, finding that the full library has overall an excellent potential as leads. The SwissADME analysis shown that the compounds did not present PAINS alerts. Although most of the compounds violated at least one of Lipinski and Ghose rules, mostly due to high MW, they presented better Veber, Egan and Muegge parameters, achieving overall proper druglike parameters. According to pkCSM prediction, all the active compounds 
present good ADME-Tox properties. The library presented good absorption parameters, with a moderate Caco2 permeability, high GI absorption and good skin permeability. The volumes of distribution (VDss) are moderate to high, and it is most likely that the compounds remain bound to serum proteins, as we could expect from their low solubility parameters, which could difficult the distribution process. The compounds could act as both substrate and inhibitor of CYP3A4, a main enzyme responsible of drug metabolism. Hence, the implications on the metabolism of these drugs should be further studied. Regarding excretion, good clearance parameters were predicted. Also, the compounds did not present signs of being mutagenic, irritant, teratogenic or toxic to sexual reproduction. All compounds presented hepatotoxicity alerts, which could be related to the CYP3A4 inhibition, and more studies should be made to address this issue.

In order to have a deeper insight of the lipophilicity requirements for this collection, we graphed $\log \mathrm{D}_{7.4}$ vs $I \mathrm{C}_{50}$ for each parasite (Figure 3). Since our compounds have ionizable groups that are charged at physiological $\mathrm{pH}, \operatorname{LogD}(\mathrm{pH}=7.4)$ [27] results a better lipophilicity descriptor than CLogP, and the former was used in the SAR analysis. Although there is no clear correlation between $\log \mathrm{D}$ and $I \mathrm{C}_{50}$, due to the high structural similarity between the analogs, we could determine $\log \mathrm{D}$ zones where there is a higher appearance of active analogs. For $L$. donovani, the most active compounds have logD between 4 and 5.6. T. brucei seems to require compounds with $\log \mathrm{D}$ greater than 4. And finally, the requirements for $T$. cruzi are less clear, since the collection resulted to be less active against this parasite. In this case, we found a small island of activity at $\log \mathrm{D}$ between 4 and 5.5 . 

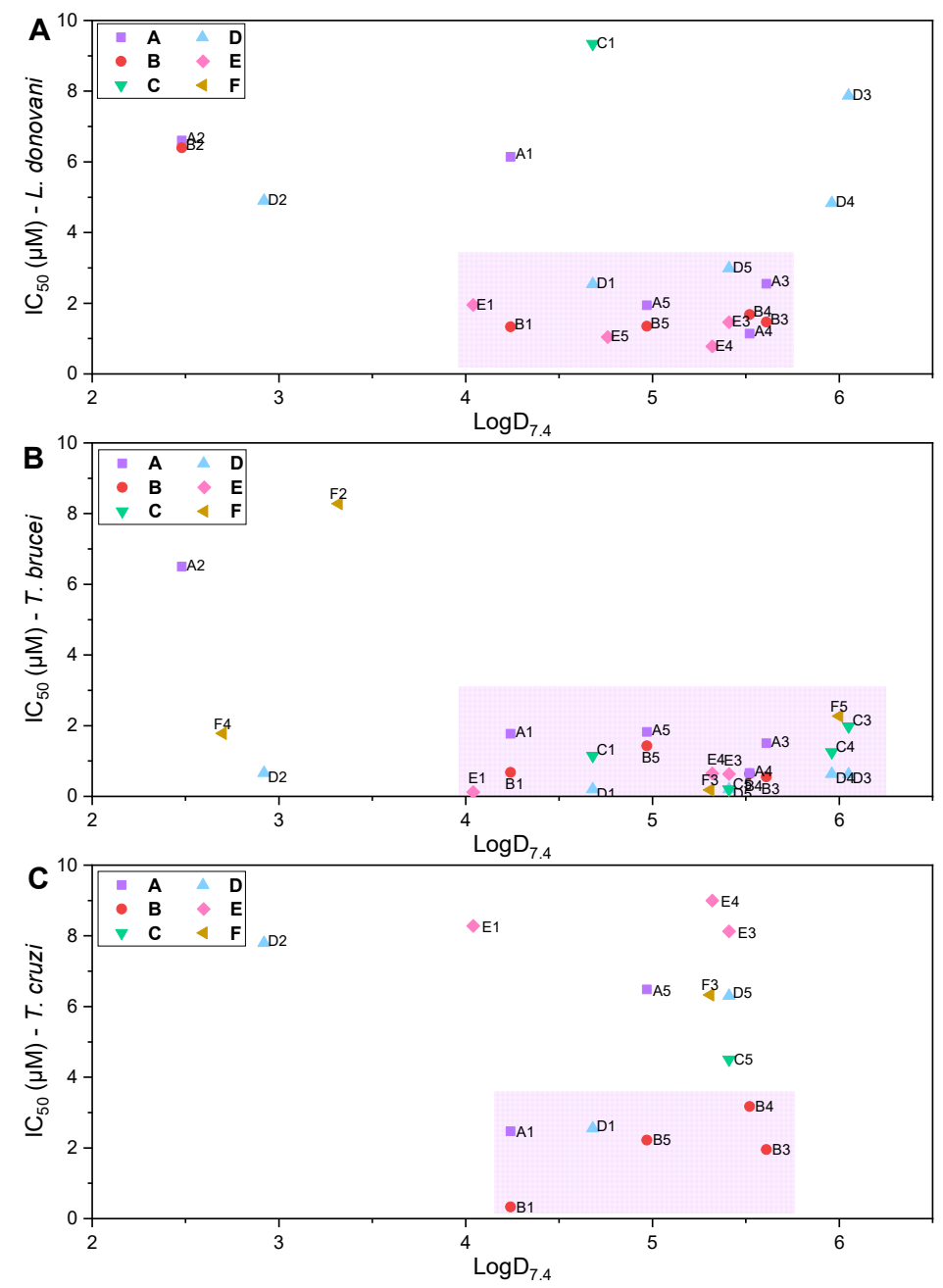

Figure 3. Correlation between antiparasitic activity and $\log \mathrm{D}_{7.4 .}$ A) L. donovani; B) T. brucei; C) T. cruzi.

In T. brucei, a very important property to be considered is the capability of a drug to permeate the CNS, in order to be curative in the cerebral more serious phase of HAT. Although the BBB permeability prediction by pkCSM and SwissADME indicate that the compounds would not be capable to permeate the brain-blood barrier, there is still a good chance that the compounds could permeate the CNS through other mechanisms (Figure 4). One critical parameter to determine if a compound could be able to penetrate the CNS is the polar surface area (PSA), which usually does not exceed the $70 \AA^{2}$ for most of CNS penetrant drugs.[30] Generally, PSA values negatively correlate with passive CNS permeability, hence low PSA could translate in higher drug concentration in brain. It can be appreciated in Figure 4 that many of the active compounds have proper CNS permeability (calculated as logPS: blood-brain permeability-surface area product), which correlates with their low PSA. It can be observed that the compounds included in the shadowed box in Figure 4 mainly belong to the families A, B, C and D. These compounds will constitute excellent candidates to apply further structural optimization and improve brain penetration. 


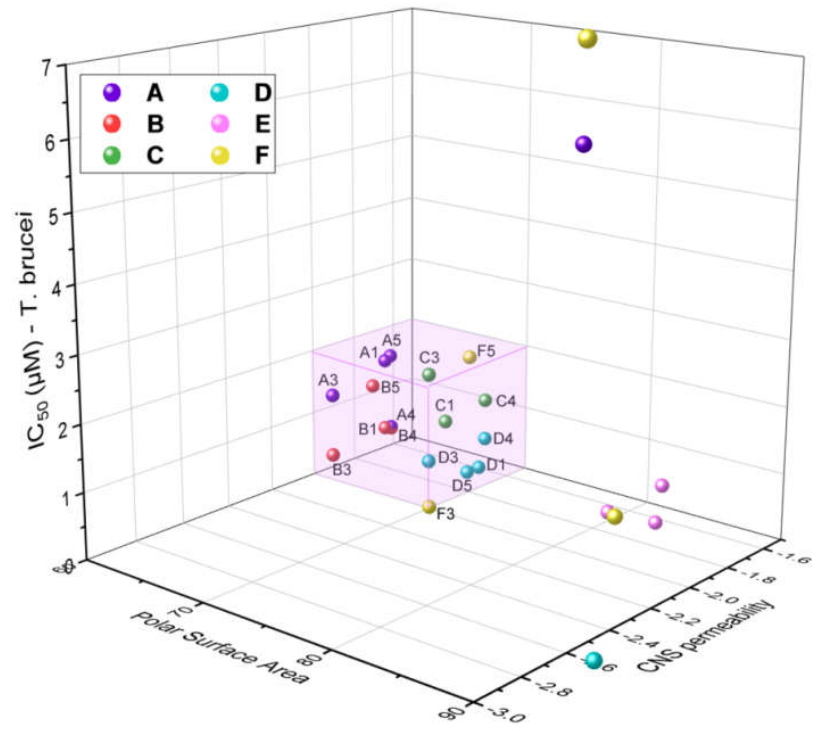

Figure 4. Correlation between anti-T. brucei activity, CNS permeability (logPS) and polar surface area. The shadowed box indicates the zone where probability to permeate CNS is higher.

\section{Conclusions}

A library of 30 triazolyl sterols was successfully synthesized and characterized, with an average yield of $82 \%$ in the $\mathrm{Cu}(\mathrm{I})$ catalyzed cycloaddition. The synthesis of these triazolyl sterols were divided into 6 families. The first four (A, B, C and D) were prepared to emulate the carbocation intermediate of the enzyme 24-SMT. Families $\mathbf{C}$ and $\mathbf{D}$ have acetates, following the rational proposed by Nes (improvement of permeability through the membrane and subsequent hydrolysis and action on target/s). Families $\mathbf{E}$ and $\mathbf{F}$ constitute a chimera/hybrid approximation between 22,26-Azasterol (AZA) and our first-generation library.

The selection of the best drug candidate as antiparasitic should combine low $I C_{50}$ values with good physicochemical parameters, low cytotoxicity (high SI) and good CNS penetration (for $T$. brucei). Figure $\mathbf{S} 1$ (Supporting information) shows the relationship between structure and activity of our library against the in vitro activity tested in all parasites. Fortunately, none of the compounds showed cytotoxic activity in VERO cells at concentrations less than $10 \mu \mathrm{M}$.

The compounds showed an excellent activity against $L$. donovani, with the most active compounds being 8 and 6 times more active than pentamidine, respectively (compound E4, $I_{50}=780 \mathrm{nM}, S I>11.36$; compound $\left.E 5, \quad I C_{50}=1.04 \mu \mathrm{M}, \mathrm{SI}>8.77\right)$. Both present good physicochemical and ADME-Tox properties, and represent excellent candidates to move towards a next stage in the search for new antileishmanial agents. In this case, the chimera molecules constituted the best scaffold.

Chimeric E1 $\left(\mathrm{IC}_{50}=120 \mathrm{nM}, \mathrm{SI}>\mathrm{80.32}\right)$ was the most active candidate against $T$. brucei. Nonetheless, its higher polarity could be a downwards for a good CNS penetration, and could not be used for treatment of cerebral phase of HAT. Compounds C5, D1 and D5, all presenting an $\mathrm{IC}_{50}$ 
$=200 \mathrm{nM}$, with less polar groups, have the best properties for a potential brain penetration and are excellent candidates for further structural optimization.

The most promising member against $T$. cruzi is $\mathbf{B} 1\left(\mathrm{IC}_{50}=330 \mathrm{nM}, \mathrm{SI}>31.00\right)$, a structure 24 times more active than Nifurtimox and 22 times more active than Benznidazole. In this case, this compound combines the best activity with excellent physicochemical properties, constituting a spearhead in the search for new anti-chagasic compounds.

The loss of activity of $\mathbf{F}$ family compounds, allows us to successfully conclude the need to position a basic group on the side chain. This is in complete line with the hypothesis of the emulation of the carbocation intermediate.

Finally, based on the structural similarities between Gilbert's compounds and ours, it is possible that 1,2,3-triazolyl sterols can also interfere with the activity of sterol methyltransferase, and we plan on testing this hypothesis as we continue our work with triazolylsterols.

\section{Material and Methods}

\subsection{General Information}

${ }^{1} \mathrm{H}$ and ${ }^{13} \mathrm{C}$ NMR spectra were acquired on a Bruker Avance II $300 \mathrm{MHz}(75.13 \mathrm{MHz})$ using $\mathrm{CDCl}_{3}$ as solvent. Chemical shifts $(\delta)$ were reported in ppm downfield from tetramethylsilane (TMS) at $0 \mathrm{ppm}$ as internal standard and coupling constants $(J)$ are in hertz $(\mathrm{Hz})$. Chemical shifts for carbon nuclear magnetic resonance $\left({ }^{13} \mathrm{C}\right.$ NMR) spectra are reported in parts per million relatives to the center line of the $\mathrm{CDCl}_{3}$ triplet at $76.9 \mathrm{ppm}$. The following abbreviations are used to indicate NMR signal multiplicities: $\mathrm{s}=\mathrm{singlet}, \mathrm{d}$ $=$ doublet, $\mathrm{t}=$ triplet, $\mathrm{q}=$ quartet, $\mathrm{m}=$ multiplet, $\mathrm{p}=$ pentet, $\mathrm{br}=$ broad signal. High-resolution mass spectra (HRMS) were recorded on a Bruker MicroTOF II with lock spray source. IR spectra were obtained using an FTIR Shimadzu spectrometer and only partial spectral data are listed. Chemical reagents were purchased from commercial suppliers and used without further purification, unless otherwise noted. Solvents were analytical grade or were purified by standard procedures prior to use. Yields were calculated for material judged homogeneous by thin layer chromatography (TLC) and nuclear magnetic resonance $\left({ }^{1} \mathrm{H}-\mathrm{NMR}\right)$. All reactions were monitored by thin layer chromatography performed on silica gel $60 \mathrm{~F}_{254}$ pre-coated aluminum sheets, visualized by a $254 \mathrm{~nm}$ UV lamp, and stained with an ethanolic solution of 4-anisaldehyde. Column flash chromatography was performed using silica gel 60 (230-400 mesh).

\subsection{Synthesis}

4.2.1. Synthesis of (3S,8S,9S,10R,13S,14S,17S)-17-acetyl-10,13-dimethyl2,3,4,7,8,9,10,11,12,13,14,15,16,17-tetradecahydro-1H-cyclopenta[a]phenanthren-3-yl acetate (6) 
Pregnenolone $(2.00 \mathrm{~g}, 6.33 \mathrm{mmol})$ was dissolved in pyridine $(30 \mathrm{~mL})$ at $0^{\circ} \mathrm{C}$. Then, acetic anhydride (30 $\mathrm{mL}$ ) was added dropwise. The mixture stirred overnight at room temperature. Water $(100 \mathrm{~mL})$ was added and the solution was extracted with AcOEt $(3 \times 50 \mathrm{~mL})$. Combined organic phases were sequentially washes with $10 \% \mathrm{HCl}(1 \times 30 \mathrm{~mL}), 10 \% \mathrm{NaHCO}_{3}(1 \times 30 \mathrm{~mL})$, water $(2 \times 30 \mathrm{~mL})$, and finally brine $(1 \times 30 \mathrm{~mL})$. The organic extract was dried over sodium sulfate and evaporated. Pregnenolone acetate 6 was purified by column chromatography in silica gel with increasing hexane/ethyl acetate to afford $2.22 \mathrm{~g}$ of a white crystalline solid (isolated yield: 98\%). NMR and HRMS shows that the product was pure and is consistent with that reported by literature [31].

4.2.2. Synthesis of $(3 \mathrm{~S}, 8 \mathrm{~S}, 9 \mathrm{~S}, 10 \mathrm{R}, 13 \mathrm{~S}, 14 \mathrm{~S}, 17 \mathrm{~S})-10,13-$ dimethyl-17-((R)-1-(prop-2-yn-1ylamino)ethyl)-2,3,4,7,8,9,10,11,12,13,14,15,16,17-tetradecahydro-1H-cyclopenta[a]phenanthren-3yl acetate (C) and (3S,8S,9S,10R,13S,14S,17S)-10,13-dimethyl-17-((S)-1-(prop-2-yn-1-ylamino)ethyl)2,3,4,7,8,9,10,11,12,13,14,15,16,17-tetradecahydro-1H-cyclopenta[a]phenanthren-3-yl acetate (D)

To a solution of pregnenolone acetate $(1.0 \mathrm{~g}, 2.80 \mathrm{mmol})$ in $20 \mathrm{~mL}$ of THF, propargylamine $(0.93 \mathrm{~g}, 16.80 \mathrm{mmol}), \mathrm{NaBH}(\mathrm{AcO})_{3}(1.18 \mathrm{~g}, 5.60 \mathrm{mmol})$ and finally $4 \AA$ molecular sieves $(100 \mathrm{mg}$ ) were added in this order and the reaction mixture was stirred at room temperature. Additional molecular sieves were added every $48 \mathrm{~h}$ until the reaction was completed in 1 week. Then, the reaction was quenched by addition of $5 \% \mathrm{NaHCO}_{3}(50$ $\mathrm{mL}$ ) and the layers were separated and filtered to remove the molecular sieves. The aqueous phase was extracted with ether $(4 \times 20 \mathrm{~mL})$. Combined organic extracts were dried over $\mathrm{Na}_{2} \mathrm{SO}_{4}$ and concentrated. The products were purified by column chromatography in silica gel with increasing ethyl acetate/hexane gradient to yield a less polar fraction composed by C, $627 \mathrm{mg}, 49 \%$ (light-yellow solid), and a more polar fraction containing D, $615 \mathrm{mg}, 48 \%$ (light-yellow solid).

4.2.2.1 $\quad(3 S, 8 S, 9 S, 10 R, 13 S, 14 S, 17 S)-10,13-d i m e t h y l-17-((R)-1-(p r o p-2-y n-1-y l a m i n o) e t h y l)-$ 2,3,4,7,8,9,10,11,12,13,14,15,16,17-tetradecahydro-1H-cyclopenta[a]phenanthren-3-yl acetate (C)

${ }^{1} \mathrm{H}$ NMR (300 MHz, CDCl $) \delta 5.37$ (d, 1H, J = 5.1 Hz, C6-H); $4.70-4.49(\mathrm{~m}, 1 \mathrm{H}, \mathrm{C} 3-\mathrm{H})$; 3.49 (dd, $1 \mathrm{H}, J=17.3,2.5 \mathrm{~Hz}, \mathrm{NH}-\mathrm{CH}_{2}$ ), 3.35 (dd, $1 \mathrm{H}, J=17.2,2.4 \mathrm{~Hz}, \mathrm{NH}-\mathrm{CH}_{2}$ ); 2.84 (dd, $1 \mathrm{H}, J=9.1,6.0 \mathrm{~Hz}, \mathrm{C} 20-\mathrm{H}) ; 2.31(\mathrm{~m}, 2 \mathrm{H}, \mathrm{C} 4-\mathrm{H}) ; 2.18(\mathrm{t}, 1 \mathrm{H}, J=2.4 \mathrm{~Hz},-\mathrm{C} \equiv \mathrm{CH}) ; 2.02(\mathrm{~s}$, $\left.3 \mathrm{H},-\mathrm{COCH}_{3}\right) ; 2.01-1.91(\mathrm{~m}, 2 \mathrm{H}) ; 1.85(\mathrm{~m}, 3 \mathrm{H}) ; 1.69-1.40(\mathrm{~m}, 9 \mathrm{H}) ; 1.31(\mathrm{~m}, \mathrm{~J}=6.1 \mathrm{~Hz}$, $3 \mathrm{H}) ; 1.20-1.04(\mathrm{~m}, 3 \mathrm{H}) ; 1.04-0.93(\mathrm{~m}, 8 \mathrm{H}) ; 0.91-0.82(\mathrm{~m}, 2 \mathrm{H}) ; 0.76(\mathrm{~s}, 3 \mathrm{H}, \mathrm{C} 18-\mathrm{H}) .{ }^{13} \mathrm{C}$ NMR (75 MHz, CDCl $\left.{ }_{3}\right)$ ठ $170.5(\mathrm{C}=\mathrm{O}) ; 139.6(\mathrm{C}, \mathrm{C} 5) ; 122.5(\mathrm{CH}, \mathrm{C} 6) ; 82.6(\mathrm{CH}, \equiv \mathrm{CH}) ; 73.9$ (CH, C3); $71.0(\mathrm{C},-\mathrm{C} \equiv) ; 56.3(\mathrm{CH}) ; 56.2(\mathrm{CH}) ; 53.8(\mathrm{CH}) ; 49.8(\mathrm{CH}) ; 42.0(\mathrm{C}) ; 40.2\left(\mathrm{CH}_{2}\right)$; $38.1\left(\mathrm{CH}_{2}\right) ; 37.0\left(\mathrm{CH}_{2}\right) ; 36.6(\mathrm{C}) ; 34.9\left(-\mathrm{NH}-\mathrm{CH}_{2}\right) ; 31.8(\mathrm{CH}) ; 31.7\left(\mathrm{CH}_{2}\right) ; 27.7\left(\mathrm{CH}_{2}\right) ; 26.7$ $\left(\mathrm{CH}_{2}\right) ; 24.1\left(\mathrm{CH}_{2}\right) ; 21.4\left(\mathrm{CH}_{2}\right) ; 21.0\left(\mathrm{CH}_{2}\right) ; 19.3\left(\mathrm{CH}_{3}\right) ; 18.5\left(\mathrm{CH}_{2}\right) ; 12.3\left(\mathrm{CH}_{3}\right)$. IR $u_{\max } 3305$ (=C-H); $2942(\mathrm{C}-\mathrm{H}) ; 1732(\mathrm{C}=\mathrm{O}) ; 1453\left(-\mathrm{CH}_{2}-\mathrm{C} \equiv\right) \mathrm{cm}^{-1}$. HRMS calculated mass for $\mathrm{C}_{26} \mathrm{H}_{40} \mathrm{NO}_{2}\left(\mathrm{M}+\mathrm{H}^{+}\right)$398.3054; found $\mathrm{m} / \mathrm{z} 398.3058$. 
${ }^{1} \mathrm{H}$ NMR $\left(300 \mathrm{MHz}, \mathrm{CDCl}_{3}\right) \delta 5.37(\mathrm{~d}, 1 \mathrm{H}, J=5.2 \mathrm{~Hz}, \mathrm{C} 6-\mathrm{H}) ; 4.67-4.54(\mathrm{~m}, 1 \mathrm{H}, \mathrm{C} 3-\mathrm{H})$; 3.48 (dd, $1 \mathrm{H}, J=17.2,2.5 \mathrm{~Hz}, \mathrm{NH}-\mathrm{CH}_{2}$ ); 3.34 (dd, $1 \mathrm{H}, J=17.2,2.4 \mathrm{~Hz}, \mathrm{NH}-\mathrm{CH}_{2}$ ); 2.75 (dd, $1 \mathrm{H}, J=9.4,6.1 \mathrm{~Hz}, \mathrm{C} 20-\mathrm{H}) ; 2.32(\mathrm{~m}, 2 \mathrm{H}, \mathrm{C} 4-\mathrm{H}) ; 2.18(\mathrm{t}, 1 \mathrm{H}, J=2.4 \mathrm{~Hz},-\mathrm{C} \equiv \mathrm{CH}) ; 2.03(\mathrm{~s}$, $\left.3 \mathrm{H},-\mathrm{COCH}_{3}\right) ; 2.01-1.76(\mathrm{~m}, 5 \mathrm{H}) ; 1.52(\mathrm{~m}, 10 \mathrm{H}) ; 1.38-1.11(\mathrm{~m}, 4 \mathrm{H}) ; 1.11-0.88(\mathrm{~m}, 9 \mathrm{H})$; 0.72 (s, 3H, C18-H). ${ }^{13} \mathrm{C}$ NMR (75 MHz, $\left.\mathrm{CDCl}_{3}\right) \delta 170.5(\mathrm{C}=\mathrm{O}) ; 139.7(\mathrm{C}, \mathrm{C} 5) ; 122.5(\mathrm{CH}$, C6); $82.6(\mathrm{CH}, \equiv \mathrm{CH}) ; 73.9(\mathrm{CH}, \mathrm{C} 3) ; 71.0(\mathrm{C},-\mathrm{C} \equiv) ; 56.6(\mathrm{CH}) ; 56.3(\mathrm{CH}) ; 54.5(\mathrm{CH}) ; 49.9$ $(\mathrm{CH}) ; 42.1(\mathrm{C}) ; 39.3\left(\mathrm{CH}_{2}\right) ; 38.1\left(\mathrm{CH}_{2}\right) ; 37.0\left(\mathrm{CH}_{2}\right) ; 36.6(\mathrm{C}) ; 35.1\left(-\mathrm{NH}-\mathrm{CH}_{2}\right) ; 31.8(\mathrm{CH})$; $31.7\left(\mathrm{CH}_{2}\right) ; 27.7\left(\mathrm{CH}_{2}\right) ; 26.9\left(\mathrm{CH}_{2}\right) ; 24.2\left(\mathrm{CH}_{2}\right) ; 21.4\left(\mathrm{CH}_{2}\right) ; 20.9\left(\mathrm{CH}_{2}\right) ; 19.3\left(\mathrm{CH}_{3}\right) ; 18.6$ $\left(\mathrm{CH}_{3}\right) ; 12.3\left(\mathrm{CH}_{3}\right)$. IR U $\max 3268(\equiv \mathrm{C}-\mathrm{H}) ; 2940(\mathrm{C}-\mathrm{H}) ; 1733(\mathrm{C}=\mathrm{O}) ; 1466\left(-\mathrm{CH}_{2}-\mathrm{C} \equiv\right) \mathrm{cm}^{-1}$. HRMS calculated mass for $\mathrm{C}_{26} \mathrm{H}_{40} \mathrm{NO}_{2}\left(\mathrm{M}+\mathrm{H}^{+}\right) 398.3054$; found $\mathrm{m} / \mathrm{z} 398.3058$.

4.2.3. Synthesis of $1-((3 S, 8 S, 9 S, 10 R, 13 S, 14 S, 17 S)-3-((t e r t-b u t y l d i m e t h y l s i l y l) o x y)-10,13-d i m e t h y l-$ 2,3,4,7,8,9,10,11,12,13,14,15,16,17-tetradecahydro-1H-cyclopenta[a]phenanthren-17-yl)ethan-1-one (7)

Pregnenolone $(2.00 \mathrm{~g}, 6.33 \mathrm{mmol})$ was dissolved in DMF $(50 \mathrm{~mL})$ at $0{ }^{\circ} \mathrm{C}$. Then, imidazole (0.65 mg, $9.50 \mathrm{mmol})$ and 1.5 equivalents of TBDMS-Cl (1.43 g, $9.50 \mathrm{mmol})$ were successively added and the mixture stirred at room temperature for 12 hours. Water was added $(200 \mathrm{~mL})$ and the solution was extracted with diethyl ether $(3 \times 100 \mathrm{~mL})$. The combined organic phases were washed with brine $(2 \times 100 \mathrm{~mL})$, dried over sodium sulfate and evaporated. The product was purified by column chromatography in silica gel (isocratic, Hexane: EtOAc, 95:5). The product was obtained as a white solid $(2.53 \mathrm{~g}, 93 \%$ yield $) .{ }^{1} \mathrm{H}$ NMR (300 MHz, CDCl 3 ) $5.31(\mathrm{~d}, 1 \mathrm{H}, J=5.2 \mathrm{~Hz}, \mathrm{C} 6-\mathrm{H}) ; 3.48(\mathrm{~m}, 1 \mathrm{H}, \mathrm{C} 3-\mathrm{H}) ; 2.52(\mathrm{t}, 1 \mathrm{H}, J$ $=8.8 \mathrm{~Hz}, \mathrm{C} 17-\mathrm{H}) ; 2.12(\mathrm{~m}, 6 \mathrm{H}) ; 2.03(\mathrm{~m}, 2 \mathrm{H}) ; 1.91-1.34(\mathrm{~m}, 11 \mathrm{H}) ; 1.33-0.94(\mathrm{~m}, 7 \mathrm{H}) ; 0.88$ (s, 9H, Si-C $\left.\left(\mathrm{CH}_{3}\right)_{3}\right) ; 0.62(\mathrm{~s}, 3 \mathrm{H}, \mathrm{C} 18-\mathrm{H}) ; 0.05$ (s, 6H, Si-CH 3$) .{ }^{13} \mathrm{C} \mathrm{NMR}\left(75 \mathrm{MHz}, \mathrm{CDCl}_{3}\right) \delta$ 209.6 (C=O), 141.5 (C5), 120.9 (C6), 72.5 (C3), 63.7 (C17), 57.0 (C14), 50.1 (C9), 44.0 (C13), $42.8\left(\mathrm{CH}_{2}\right), 38.9\left(\mathrm{CH}_{2}\right), 37.4\left(\mathrm{CH}_{2}\right), 36.6(\mathrm{C} 10), 32.0\left(\mathrm{CH}_{2}\right), 31.9\left(\mathrm{CH}_{2}\right), 31.8\left(\mathrm{CH}_{2}\right)$, $31.5(\mathrm{C} 21), 25.9\left(\mathrm{Si}-\mathrm{C}\left(\mathrm{CH}_{3}\right)_{3}\right), 24.5\left(\mathrm{CH}_{2}\right), 22.8\left(\mathrm{CH}_{2}\right), 21.1\left(\mathrm{CH}_{2}\right), 19.4(\mathrm{C} 19), 18.3(\mathrm{Si}-\mathrm{C}-)$, $13.2(\mathrm{C} 18),-4.6\left(\mathrm{Si}-\mathrm{CH}_{3}\right)$. IR $v_{\max } 2955(\mathrm{C}-\mathrm{H}) ; 1700 \quad(\mathrm{C}=\mathrm{O}) ; 1243\left(\mathrm{Si}-\mathrm{CH}_{3}\right)$. HRMS calculated mass for $\mathrm{C}_{27} \mathrm{H}_{47} \mathrm{O}_{2} \mathrm{Si}\left(\mathrm{M}+\mathrm{H}^{+}\right)$431.3334; found $\mathrm{m} / \mathrm{z} 431.3355$.

4.2.4. Synthesis of tert-butyl(((3S,8S,9S,10R,13S,14S,17S)-10,13-dimethyl-17-((R)-2-methyloxiran2-yl)-2,3,4,7,8,9,10,11,12,13,14,15,16,17-tetradecahydro-1H-cyclopenta[a]phenanthren-3yl)oxy)dimethylsilane (8)

$\mathrm{NaH}$ (336 mg, $14 \mathrm{mmol}$ ) were dissolved in DMSO (50 $\mathrm{mL})$ and trimethylsulfonium iodide $(1.44 \mathrm{~g}, 18.64 \mathrm{mmol})$ were added. The mixture was vigorously stirred for 2 hours at room temperature. Then, $7(2.00 \mathrm{~g}, 4.66 \mathrm{mmol})$ was added. After 18 hours at room temperature, 
water was added to the mixture. The solution was extracted with diethyl ether $(3 \times 100 \mathrm{~mL})$. The combined organic phases were washed successively with water $(2 \times 100 \mathrm{~mL})$ and brine $(1 \times 100 \mathrm{~mL})$, dried over sodium sulfate and evaporated. The product was purified by column chromatography in silica gel (in gradient, using hexane and ethyl acetate). The product was obtained as a white solid $\left(1.88 \mathrm{~g}, 91 \%\right.$ yield). ${ }^{1} \mathrm{H} \mathrm{NMR}\left(300 \mathrm{MHz} \mathrm{CDCl}_{3}\right) \delta$ $5.31(\mathrm{~d}, 1 \mathrm{H}, J=5.1 \mathrm{~Hz}, \mathrm{C} 6-\mathrm{H}) ; 3.48(\mathrm{dt}, 1 \mathrm{H}, J=11.0,5.6 \mathrm{~Hz}, \mathrm{C} 3-\mathrm{H}) ; 2.50(\mathrm{~d}, 1 \mathrm{H}, J=4.9$ $\left.\mathrm{Hz}, \mathrm{O}-\mathrm{CH}_{2}\right) ; 2.32\left(\mathrm{~d}, 1 \mathrm{H}, J=5.0 \mathrm{~Hz}, \mathrm{O}-\mathrm{CH}_{2}\right) ; 2.28-1.88(\mathrm{~m}, 4 \mathrm{H}) ; 1.88-1.33(\mathrm{~m}, 15 \mathrm{H})$; $1.33-0.96(\mathrm{~m}, 8 \mathrm{H}) ; 0.89\left(\mathrm{~s}, 9 \mathrm{H}, \mathrm{Si}-\mathrm{C}\left(\mathrm{CH}_{3}\right)_{3}\right) ; 0.81(\mathrm{~s}, 3 \mathrm{H}, \mathrm{C} 18) ; 0.05\left(\mathrm{~s}, 6 \mathrm{H}, \mathrm{Si}-\mathrm{CH}_{3}\right) .{ }^{13} \mathrm{C}$ NMR (75 MHz, CDCl3) ס 141.6 (C, C5); $121.0(\mathrm{CH}, \mathrm{C6}) ; 72.6(\mathrm{CH}, \mathrm{C} 3) ; 56.7$ (CH, C14); $56.1(\mathrm{C}) ; 54.2(\mathrm{CH}) ; 51.6\left(\mathrm{CH}_{2}, \mathrm{C} 22\right) ; 50.1(\mathrm{CH}, \mathrm{C} 9) ; 44.0(\mathrm{C}) ; 42.8\left(\mathrm{CH}_{2}\right) ; 39.5\left(\mathrm{CH}_{2}\right) ; 37.4$ $\left(\mathrm{CH}_{2}\right) ; 36.6(\mathrm{C}) ; 32,0\left(\mathrm{CH}_{2}\right) ; 31.7\left(\mathrm{CH}_{2}\right) ; 31.8\left(\mathrm{CH}_{2}\right) ; 25,9\left(\mathrm{CH}_{3}, \mathrm{C}\left(\mathrm{CH}_{3}\right)_{3}\right), 23.8\left(\mathrm{CH}_{2}\right) ; 22.6$ $\left(\mathrm{CH}_{3}\right) ; 21.8\left(\mathrm{CH}_{2}\right) ; 20: 9\left(\mathrm{CH}_{2}\right) ; 19.4\left(\mathrm{CH}_{3}\right) ; 18,3$ (C, Si-C-); $13.0\left(\mathrm{CH}_{3}\right) ;-4,6\left(\mathrm{CH}_{3}, \mathrm{Si}-\mathrm{CH}_{3}\right)$. IR $u_{\max } 3040$ (=C-H), 2933 (-C-H), 2955 (C-H); 1230 (Si-CH $), 940$ (C-O). HRMS calculated mass for $\mathrm{C}_{28} \mathrm{H}_{49} \mathrm{O}_{2} \mathrm{Si}\left(\mathrm{M}+\mathrm{H}^{+}\right)$445.3496; found $\mathrm{m} / \mathrm{z} 445.3485$.

4.2.5. Synthesis of $(R)-2-((3 S, 8 S, 9 S, 10 R, 13 S, 14 S, 17 S)-3-((t e r t-b u t y l d i m e t h y l s i l y l) o x y)-10,13-$ dimethyl-2,3,4,7,8,9,10,11,12,13,14,15,16,17-tetradecahydro-1H-cyclopenta[a]phenanthren-17-yl)-1(prop-2-yn-1-ylamino)propan-2-ol (9)

Epoxide 8 (900 mg, $2.02 \mathrm{mmol})$ was dissolved in $\mathrm{CH}_{3} \mathrm{CN}(30 \mathrm{~mL})$. $\mathrm{LiClO}_{4}(6.45 \mathrm{~g}, 60$ $\mathrm{mmol}$ ) and propargyl bromide $(1.20 \mathrm{~g}, 10.1 \mathrm{mmol})$ were slowly added at room temperature. Then the mixture was heated until boiling for 5 days. Finally, water $(100 \mathrm{~mL})$ was added and the solution was extracted with DCM $(3 \times 30 \mathrm{~mL})$. The combined organic phases were dried with sodium sulfate and evaporated. The product was purified by chromatography in a silica gel column (in gradient, Hexane-AcOEt). The product was obtained as a light-yellow solid (881 mg, 87\% yield). ${ }^{1} \mathrm{H}$ NMR (300 MHz, $\left.\mathrm{CDCl}_{3}\right) \delta 5.31$ (d, $\left.1 \mathrm{H}, J=5.0 \mathrm{~Hz}, \mathrm{C} 6-\mathrm{H}\right) ; 3.56$ $-3.35\left(\mathrm{~m}, 3 \mathrm{H}, \mathrm{NH}-\mathrm{CH}_{2}, \mathrm{C} 3-\mathrm{H}\right) ; 2.59(\mathrm{~s}, 2 \mathrm{H}, \mathrm{C} 22-\mathrm{H}) ; 2.22(\mathrm{t}, 1 \mathrm{H}, \mathrm{J}=2.4 \mathrm{~Hz}, \equiv \mathrm{CH}) ; 2.37-$ $1.90(\mathrm{~m}, 4 \mathrm{H}) ; 1.90-1.33(\mathrm{~m}, 16 \mathrm{H}) ; 1.24(\mathrm{~s}, 6 \mathrm{H}) ; 1.00(\mathrm{~m}, 5 \mathrm{H}) ; 0.89(\mathrm{~s}, 9 \mathrm{H}, J=0.9 \mathrm{~Hz}$, $\left.\mathrm{SiC}\left(\mathrm{CH}_{3}\right)_{3}\right) ; 0.85(\mathrm{~s}, 3 \mathrm{H}, \mathrm{C} 18-\mathrm{H}) ; 0.06\left(\mathrm{~s}, 6 \mathrm{H}, \mathrm{Si}-\mathrm{CH}_{3}\right) .{ }^{13} \mathrm{C} \mathrm{NMR}\left(75 \mathrm{MHz}, \mathrm{CDCl}_{3}\right) \delta 141.6$ (C, C5); $121.1(\mathrm{CH}, \mathrm{C} 6) ; 82.2(\mathrm{CH}, \equiv \mathrm{CH}) ; 73.4(\mathrm{CH}, \mathrm{C} 3) ; 72.6(\mathrm{C}, \mathrm{C} 20) ; 71.3(\mathrm{C},-\mathrm{C} \equiv) ; 58.7$ $\left(\mathrm{CH}_{2}\right) ; 57.5(\mathrm{CH}) ; 57.0(\mathrm{CH}) ; 50.2(\mathrm{CH}) ; 42.8(\mathrm{C}) ; 42.7\left(\mathrm{CH}_{2}\right) ; 40.1(\mathrm{C}) ; 39.0\left(\mathrm{CH}_{2}\right) ; 37.4$ $\left(\mathrm{CH}_{2}\right) ; 36.6(\mathrm{C}) ; 32.1\left(\mathrm{CH}_{2}\right) ; 31.8(\mathrm{CH}) ; 31.4\left(\mathrm{CH}_{2}\right) ; 25.9\left(\mathrm{CH}_{3}, \mathrm{C}\left(\mathrm{CH}_{3}\right)_{3}\right) ; 25.1\left(\mathrm{CH}_{3}\right) ; 23.9$ $\left(\mathrm{CH}_{2}\right) ; 22.5\left(\mathrm{CH}_{2}\right) ; 20.9\left(\mathrm{CH}_{2}\right) ; 19.4\left(\mathrm{CH}_{3}\right) ; 18.3(\mathrm{Si}-\mathrm{C}) ; 13.5\left(\mathrm{CH}_{3}\right) ;-4.6\left(\mathrm{Si}-\mathrm{CH}_{3}\right)$. IR u $\max$ $3443(\mathrm{O}-\mathrm{H}), 3308(\equiv \mathrm{C}-\mathrm{H}) ; 2942(\mathrm{C}-\mathrm{H}) ; 1240$ (Si-C). HRMS calculated mass for $\mathrm{C}_{31} \mathrm{H}_{54} \mathrm{NO}_{2} \mathrm{Si}$ $\left(\mathrm{M}+\mathrm{H}^{+}\right)$500.3918; found $\mathrm{m} / \mathrm{z} 500.3930$.

4.2.6. Synthesis of $(3 S, 8 S, 9 S, 10 R, 13 S, 14 S, 17 S)-17-((R)-2$-hydroxy-1-(prop-2-yn-1-ylamino)propan2-yl)-10,13-dimethyl-2,3,4,7,8,9,10,11,12,13,14,15,16,17-tetradecahydro-1Hcyclopenta[a]phenanthren-3-ol (E) 
Terminal alkyne intermediate $9(800 \mathrm{mg}, 1.60 \mathrm{mmol})$ was dissolved in THF $(30 \mathrm{~mL})$. A solution $1 \mathrm{M}$ TBAF in THF $(3.20 \mathrm{~mL})$ was slowly added, at room temperature and stirred overnight. Water $(100 \mathrm{~mL})$ was added and the solution was extracted with diethyl ether $(3 \mathrm{x}$ $30 \mathrm{~mL}$ ). Combined organic phases were washed with water $(2 \times 50 \mathrm{~mL})$, dried over sodium sulfate and evaporated. The product was purified by chromatographic column in silica gel (in gradient, hexane-EtOAc). The product was obtained as a light-yellow solid (555 mg, 90\% yield). ${ }^{1} \mathrm{H}$ NMR (300 MHz, $\left.\mathrm{CDCl}_{3}\right) \delta 5.35$ (d, $\left.1 \mathrm{H}, J=5.1 \mathrm{~Hz}, 1 \mathrm{H}\right) ; 3.63-3.38(\mathrm{~m}, 3 \mathrm{H}$, $\left.\mathrm{NH}-\mathrm{CH}_{2}, \mathrm{C} 3-\mathrm{H}\right) ; 2.59(\mathrm{~s}, 2 \mathrm{H}, \mathrm{C} 22-\mathrm{H}) ; 2.22(\mathrm{t}, 1 \mathrm{H}, \mathrm{J}=2.4 \mathrm{~Hz}, \equiv \mathrm{CH}) ; 2.17-1.58(\mathrm{~m}, 15 \mathrm{H})$; $1.49(\mathrm{~m}, 8 \mathrm{H}) ; 1.23(\mathrm{~m}, 8 \mathrm{H}), 0.96(\mathrm{~m}, 9 \mathrm{H}), 0.86(\mathrm{~s}, 3 \mathrm{H}, \mathrm{C} 18-\mathrm{H}) .{ }^{13} \mathrm{C} \mathrm{NMR}\left(75 \mathrm{MHz}, \mathrm{CDCl}_{3}\right) \delta$ $140.8(\mathrm{C}, \mathrm{C} 5) ; 121.5(\mathrm{CH}, \mathrm{C} 6) ; 82.5(\mathrm{CH}, \equiv \mathrm{CH}) ; 72.5(\mathrm{C}, \mathrm{C} 20) ; 71.7(\mathrm{C},-\mathrm{C} \equiv) ; 71.0(\mathrm{CH}$, C3); $58.6\left(\mathrm{CH}_{2}\right) ; 57.4(\mathrm{CH}) ; 56.1(\mathrm{CH}) ; 53.8(\mathrm{CH}) ; 49.9(\mathrm{CH}) ; 42.3(\mathrm{C}) ; 42.1\left(\mathrm{CH}_{2}\right) ; 40.3(\mathrm{C})$; $39.2\left(\mathrm{CH}_{2}\right) ; 36.5(\mathrm{C}) ; 32.9\left(\mathrm{CH}_{2}\right) ; 31.8(\mathrm{CH}) ; 31.6\left(\mathrm{CH}_{2}\right) ; 25.1\left(\mathrm{CH}_{3}\right) ; 24.1\left(\mathrm{CH}_{3}\right) ; 21.1\left(\mathrm{CH}_{2}\right)$; $19.4\left(\mathrm{CH}_{3}\right) ; 18.4\left(\mathrm{CH}_{3}\right) ; 13.3\left(\mathrm{CH}_{3}\right)$. IR $u_{\max } 3480(\mathrm{O}-\mathrm{H}), 3305(\equiv \mathrm{C}-\mathrm{H}) ; 2930(\mathrm{C}-\mathrm{H}) ; 1453(-$ $\left.\mathrm{CH}_{2}-\mathrm{C} \equiv\right)$. HRMS calculated mass for $\mathrm{C}_{25} \mathrm{H}_{40} \mathrm{NO}_{2}\left(\mathrm{M}+\mathrm{H}^{+}\right) 386.3054$; found $\mathrm{m} / \mathrm{z}$ 386.3038.

4.2.7. Synthesis of (R)-1-azido-2-((3S,8S,9S,10R,13S,14S,17S)-3-((tert-butyldimethylsilyl)oxy)10,13-dimethyl-2,3,4,7,8,9,10,11,12,13,14,15,16,17-tetradecahydro-1H-cyclopenta[a]phenanthren-

\section{7-yl)propan-2-ol (10)}

Epoxide 8 (900 mg, $2.02 \mathrm{mmol})$ was dissolved in $\mathrm{CH}_{3} \mathrm{CN}(30 \mathrm{~mL})$. $\mathrm{LiClO}_{4}(9.70 \mathrm{~g}, 91$ mmol) and $\mathrm{NaN}_{3}(1.31 \mathrm{~g}, 20.2 \mathrm{mmol}$ ) were slowly added at room temperature. Then the mixture was heated until boiling for 5 days. Finally, water $(100 \mathrm{~mL})$ was added and the solution was extracted with DCM $(3 \times 30 \mathrm{~mL})$. The combined organic phases were dried with sodium sulfate and evaporated. The product was purified by chromatography in a silica gel column (isocratic, 95\% Hexane-5\% AcOEt). The product was obtained as a white solid (691 mg, 70\% yield). ${ }^{1} \mathrm{H}$ NMR (300 MHz, $\left.\mathrm{CDCl}_{3}\right) \delta 5.31$ (d, $\left.1 \mathrm{H}, J=5.2 \mathrm{~Hz}, \mathrm{C} 6-\mathrm{H}\right) ; 3.48$ (q, $1 \mathrm{H}, J=5.2 \mathrm{~Hz}, \mathrm{C} 3-\mathrm{H}) ; 3.30\left(\mathrm{~d}, 1 \mathrm{H}, J=12.0 \mathrm{~Hz}, \mathrm{~N}_{3}-\mathrm{CH}_{2}\right) ; 3.11\left(\mathrm{~d}, 1 \mathrm{H}, J=12.0 \mathrm{~Hz}, \mathrm{~N}_{3}-\mathrm{CH}_{2}\right.$ ); $2.20(\mathrm{~m}, 2 \mathrm{H} ; \mathrm{C} 4-\mathrm{H}) ; 2.06-1.45(\mathrm{~m}, 15 \mathrm{H}) ; 1.34-0.98(\mathrm{~m}, 6 \mathrm{H}) ; 0.89\left(\mathrm{~s}, 9 \mathrm{H}, \mathrm{C}\left(\mathrm{CH}_{3}\right)_{3}\right) ; 0.84(\mathrm{~s}$, $3 \mathrm{H}, \mathrm{C} 18-\mathrm{H}) ; 0.06\left(\mathrm{~s}, 6 \mathrm{H}, \mathrm{Si}-\mathrm{CH}_{3}\right) .{ }^{13} \mathrm{C} \mathrm{NMR}\left(75 \mathrm{MHz}, \mathrm{CDCl}_{3}\right) \delta 141.6(\mathrm{C}, \mathrm{C} 5) ; 121.0(\mathrm{CH}$, C6); 75.2 (C, C20); $72.6(\mathrm{CH}, \mathrm{C} 3) ; 61.5\left(\mathrm{CH}_{2}, \mathrm{C} 22\right) ; 56.8(\mathrm{CH}) ; 56.2(\mathrm{CH}) ; 50.0(\mathrm{CH}) ; 42.8$ (C); $42.7\left(\mathrm{CH}_{2}\right) ; 39.9\left(\mathrm{CH}_{2}\right) ; 37.4\left(\mathrm{CH}_{2}\right) ; 36.6(\mathrm{C}) ; 32.1\left(\mathrm{CH}_{2}\right) ; 31.8\left(\mathrm{CH}_{2}\right) ; 31.3(\mathrm{CH}) ; 25.9$ $\left(\mathrm{CH}_{3}, \mathrm{C}\left(\mathrm{CH}_{3}\right)_{3}\right) ; 24.9\left(\mathrm{CH}_{3}\right) ; 23.8\left(\mathrm{CH}_{2}\right) ; 22.3\left(\mathrm{CH}_{2}\right) ; 20.9\left(\mathrm{CH}_{2}\right) ; 19.4\left(\mathrm{CH}_{3}\right) ; 18.3(\mathrm{C}$, Si-C-); $13.6\left(\mathrm{CH}_{3}\right) ;-4,6\left(\mathrm{CH}_{3}, \mathrm{Si}-\mathrm{CH}_{3}\right)$. IR $u_{\max } 3420(\mathrm{O}-\mathrm{H}), 2951(-\mathrm{C}-\mathrm{H}), 2050\left(-\mathrm{N}_{3}\right), 1221(\mathrm{Si}-\mathrm{C})$. HRMS calculated mass for $\mathrm{C}_{28} \mathrm{H}_{50} \mathrm{~N}_{3} \mathrm{O}_{2} \mathrm{Si}\left(\mathrm{M}+\mathrm{H}^{+}\right)$488.3667; found $\mathrm{m} / \mathrm{z} 488.3674$.

4.2.8. Synthesis of $(3 S, 8 S, 9 S, 10 R, 13 S, 14 S, 17 S)-17-((R)-1$-azido-2-hydroxypropan-2-yl)-10,13dimethyl-2,3,4,7,8,9,10,11,12,13,14,15,16,17-tetradecahydro-1H-cyclopenta[a]phenanthren-3-ol (F)

Azide intermediate 10 (800 mg, $1.64 \mathrm{mmol})$ was dissolved in THF (30 mL). A solution $1 \mathrm{M}$ TBAF in THF (3.28 mL) was slowly added, at room temperature and stirred overnight. Water $(100 \mathrm{~mL})$ was added and the solution was extracted with diethyl ether $(3 \times 30 \mathrm{~mL})$. 
Combined organic phases were washed with water $(2 \times 50 \mathrm{~mL})$, dried over sodium sulfate and evaporated. The product was purified by chromatographic column in silica gel (in gradient, hexane-EtOAc). The product was obtained as a white solid (533 $\mathrm{mg}, 87 \%$ yield). ${ }^{1} \mathrm{H}$ NMR (300 MHz, CDCl $\left.{ }_{3}\right) \delta 5.35$ (d, 1H, J = 5.0 Hz, C6-H); 3.48 (q, 1H, J = 5.2 Hz, C3-H); $3.22\left(\mathrm{~d}, 1 \mathrm{H}, J=12.0 \mathrm{~Hz}, \mathrm{~N}_{3}-\mathrm{CH}_{2}\right) ; 3.18\left(\mathrm{~d}, 1 \mathrm{H}, J=12.0 \mathrm{~Hz}, \mathrm{~N}_{3}-\mathrm{CH}_{2}\right) ; 2,23(\mathrm{~m}, 2 \mathrm{H} ; \mathrm{C} 4-\mathrm{H})$; 2.06-1.38 (m, 15H); 1.34 (s, 3H, C21-H); 1-32-0.98 (m, 9H); 0.84 (s, 3H, C18-H). ${ }^{13} \mathrm{C}$ NMR $(75$

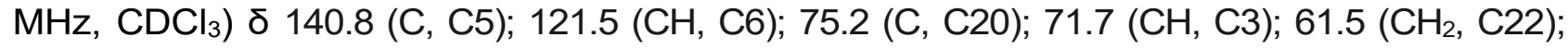
$56.7(\mathrm{CH}) ; 56.2(\mathrm{CH}) ; 50.0(\mathrm{CH}) ; 42.8(\mathrm{C}) ; 42.3\left(\mathrm{CH}_{2}\right) ; 39.9\left(\mathrm{CH}_{2}\right) ; 37.2\left(\mathrm{CH}_{2}\right) ; 36.5(\mathrm{C}) ; 31.9$ $\left(\mathrm{CH}_{2}\right) ; 31.7\left(\mathrm{CH}_{2}\right) ; 31.2(\mathrm{CH}) ; 24.9\left(\mathrm{CH}_{3}\right) ; 23.8\left(\mathrm{CH}_{2}\right) ; 22.3\left(\mathrm{CH}_{2}\right) ; 20.9\left(\mathrm{CH}_{2}\right) ; 19.4\left(\mathrm{CH}_{3}\right) ; 13,2$ $\left(\mathrm{CH}_{3}\right)$. IR $v_{\max } 3407(\mathrm{O}-\mathrm{H}), 2932(-\mathrm{C}-\mathrm{H}), 2053\left(-\mathrm{N}_{3}\right)$. HRMS calculated mass for $\mathrm{C}_{22} \mathrm{H}_{36} \mathrm{~N}_{3} \mathrm{O}_{2}$ $\left(\mathrm{M}+\mathrm{H}^{+}\right) 374.2802$; found $\mathrm{m} / \mathrm{z} 374.2806$.

\subsubsection{General procedure for the $\mathrm{Cu}(\mathrm{l})$ mediated 1,3-dipolar azide alkyne cycloaddition reaction} (CuAAC).

Alkyne (1 equivalent) and azide (1.2 equivalent) were suspended in $10 \mathrm{~mL} / \mathrm{eq}$ of $\mathrm{t}-\mathrm{BuOH}: \mathrm{H}_{2} \mathrm{O}(1: 1)$. Then, $1 \mathrm{M}$ CuSO4 solution ( 0.05 equivalents) and $1 \mathrm{M}$ sodium ascorbate solution ( 0.2 equivalents) were added, and the mixture stirred overnight at room temperature. Brine $(30 \mathrm{~mL})$ was added and the solution was extracted with dichloromethane $(3 \times 25 \mathrm{~mL})$. Combined organic extracts were dried over sodium sulfate and evaporated. Products were purified by column chromatography in silica gel with increasing hexane/ethyl acetate or dichloromethane/methanol gradients.

4.2.9.1. Synthesis of $\quad(3 \mathrm{~S}, 8 \mathrm{~S}, 9 \mathrm{~S}, 10 \mathrm{R}, 13 \mathrm{~S}, 14 \mathrm{~S}, 17 \mathrm{~S})-17-((R)-1-(((1-$ benzyl-1H-1,2,3-triazol-4yl)methyl)amino)ethyl)-10,13-dimethyl-2,3,4,7,8,9,10,11,12,13,14,15,16,17-tetradecahydro-1Hcyclopenta[a]phenanthren-3-yl acetate (C1)

Following the general reaction conditions for CuAAC reaction, the reaction was worked up and purified to afford $60 \mathrm{mg}$ of a light-yellow solid (isolated yield: $90 \%) .{ }^{1} \mathrm{H}$ NMR $\left(300 \mathrm{MHz}, \mathrm{CDCl}_{3}\right) \delta 7.36(\mathrm{~s}, 1 \mathrm{H}$, $\left.\mathrm{C}_{\text {triazole }} \mathrm{H}\right) ; 7.35$ (m, 3H, p- and m-aromatics); $7.26\left(\mathrm{~m}, 2 \mathrm{H}, o\right.$-aromatics); 5.50 (s, $2 \mathrm{H}, \mathrm{CH}_{2-}$ phenyl); $5.36(\mathrm{~d}, 1 \mathrm{H}, J=5.1 \mathrm{~Hz}, \mathrm{C} 6-\mathrm{H}) ; 4.71-4.49(\mathrm{~m}, 1 \mathrm{H}, \mathrm{C} 3-\mathrm{H}) ; 3.97(\mathrm{~d}, 1 \mathrm{H}, J=13.7 \mathrm{~Hz}$, $\left.\mathrm{NH}-\mathrm{CH}_{2}\right) ; 3.74\left(\mathrm{~d}, 1 \mathrm{H}, J=13.7 \mathrm{~Hz}, \mathrm{NH}-\mathrm{CH}_{2}\right) ; 2.62(\mathrm{~m}, 1 \mathrm{H}, \mathrm{C} 20-\mathrm{H}) ; 2.31(\mathrm{~d}, 2 \mathrm{H}, J=7.8 \mathrm{~Hz}$, $\mathrm{C} 4-\mathrm{H}) ; 2.03\left(\mathrm{~s}, 3 \mathrm{H}, \mathrm{COCH}_{3}\right) ; 2.01-1.68(\mathrm{~m}, 8 \mathrm{H}) ; 1.68-1.14(\mathrm{~m}, 11 \mathrm{H}) ; 1.15-0.88(\mathrm{~m}$, $11 \mathrm{H}) ; 0.88-0.72(\mathrm{~m}, 2 \mathrm{H}) ; 0.60(\mathrm{~s}, 3 \mathrm{H}, \mathrm{C} 18-\mathrm{H}) .{ }^{13} \mathrm{C} \mathrm{NMR}\left(75 \mathrm{MHz}, \mathrm{CDCl}_{3}\right) \delta 170.5(\mathrm{C}=\mathrm{O})$; 147.5 (C, C4triazole); 139.7 (C, C5); 134.8 (C, ipso-aromatic); 129.1 (CH, m-aromatic); 128.7 (C, p-aromatic); $128.0\left(\mathrm{CH}\right.$, o-aromatic); $122.5(\mathrm{CH}, \mathrm{C} 6) ; 121.5\left(\mathrm{CH}, \mathrm{C}_{\text {triazole }}\right) ; 73.9(\mathrm{CH}$, C3); $56.3(\mathrm{CH}) ; 56.1(\mathrm{CH}) ; 55.1(\mathrm{CH}) ; 54.1\left(\mathrm{CH} 2, \mathrm{CH}_{2}\right.$-phenyl); $49.9(\mathrm{CH}) ; 42.1\left(\mathrm{CH}_{2}, \mathrm{NH}-\right.$ $\left.\mathrm{CH}_{2}\right) ; 41.7(\mathrm{C}) ; 40.0\left(\mathrm{CH}_{2}\right) ; 38.1\left(\mathrm{CH}_{2}\right) ; 37.0\left(\mathrm{CH}_{2}\right) ; 36.6(\mathrm{C}) ; 31.8\left(\mathrm{CH}_{2}\right) ; 31.7(\mathrm{CH}) ; 27.8$ $\left(\mathrm{CH}_{2}\right) ; 26.7\left(\mathrm{CH}_{2}\right) ; 24.1\left(\mathrm{CH}_{2}\right) ; 21.4\left(\mathrm{CH}_{2}\right) ; 21.0\left(\mathrm{CH}_{2}\right) ; 19.3\left(\mathrm{CH}_{3}\right) ; 19.0\left(\mathrm{CH}_{3}\right) ; 12.2\left(\mathrm{CH}_{3}\right)$. IR $u_{\max } 3347(\mathrm{~N}-\mathrm{H}), 3025(=\mathrm{C}-\mathrm{H}), 2937(-\mathrm{C}-\mathrm{H}), 2833(-\mathrm{C}-\mathrm{H}), 1740(\mathrm{C}=\mathrm{O}), 1663 \mathrm{~cm}^{-1}$. HRMS calculated mass for $\mathrm{C}_{33} \mathrm{H}_{47} \mathrm{~N}_{4} \mathrm{O}_{2}\left(\mathrm{M}+\mathrm{H}^{+}\right)$531.3694; found $\mathrm{m} / \mathrm{z} 531.3690$. 
4.2.9.2. Synthesis of ethyl 2-(4-(((R)-1-((3S,8S,9S,10R,13S,14S,17S)-3-acetoxy-10,13-dimethyl2,3,4,7,8,9,10,11,12,13,14,15,16,17-tetradecahydro-1H-cyclopenta[a]phenanthren-17yl)ethyl)amino)methyl)-1H-1,2,3-triazol-1-yl)acetate (C2)

Following the general reaction conditions for CuAAC reaction, the reaction was worked up and purified to afford $57 \mathrm{mg}$ of a light-yellow solid (isolated yield: $86 \%)$. ${ }^{1} \mathrm{H} \mathrm{NMR}\left(300 \mathrm{MHz}, \mathrm{CDCl}_{3}\right) \delta 7.59(\mathrm{~s}, 1 \mathrm{H}$,

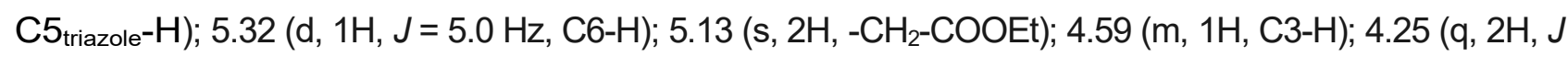
$=7.1 \mathrm{~Hz},-\mathrm{C}(\mathrm{O}) \mathrm{O}-\mathrm{CH}_{2}$ ); $4.04\left(\mathrm{~d}, 1 \mathrm{H}, J=13.8 \mathrm{~Hz}, \mathrm{NH}-\mathrm{CH}_{2}\right) ; 3.80\left(\mathrm{~d}, 1 \mathrm{H}, J=13.8 \mathrm{~Hz}, \mathrm{NH}-\mathrm{CH}_{2}\right) ; 2.67$ (m, $1 \mathrm{H}, \mathrm{C} 20-\mathrm{H}) ; 2.39$ - 2.16 (m, 2H, C4-H); 2.03 - 1.91 (m, 3H); 2.01 (s, 3H, COCH ${ }_{3} 1.91-1.67(\mathrm{~m}, 4 \mathrm{H})$; $1.47(\mathrm{~s}, 8 \mathrm{H}) ; 1.29(\mathrm{~m}, 7 \mathrm{H}) ; 1.16-0.81(\mathrm{~m}, 12 \mathrm{H}) ; 0.65(\mathrm{~s}, 3 \mathrm{H}, \mathrm{C} 18-\mathrm{H}) .{ }^{13} \mathrm{C}$ NMR $\left(75 \mathrm{MHz}, \mathrm{CDCl}_{3}\right) \delta 170.5$ $(\mathrm{C}=\mathrm{O}) ; 166.3(\mathrm{C}=\mathrm{O}) ; 147.4\left(\mathrm{C}, \mathrm{C4}_{\text {triazole }}\right) ; 140.8(\mathrm{C}, \mathrm{C} 5) ; 123.0\left(\mathrm{CH}, \mathrm{C}_{\text {triazole }}\right) ; 121.5(\mathrm{CH}, \mathrm{C} 6) ; 73.7(\mathrm{CH}$, C3); $62.4\left(\mathrm{CH}_{2},-\mathrm{OCH}_{2}\right)$; $56.4(\mathrm{CH}) ; 56.1(\mathrm{CH}) ; 55.1(\mathrm{CH}) ; 50.9\left(\mathrm{CH}_{2}, \mathrm{N1}_{\text {triazole }}-\mathrm{CH}_{2}\right) ; 50.0(\mathrm{CH}) ; 42.3\left(\mathrm{CH}_{2}\right)$; $42.1(\mathrm{C}) ; 41.6\left(\mathrm{CH}_{2}, \mathrm{NH}-\mathrm{CH}_{2}\right) ; 40.0\left(\mathrm{CH}_{2}\right) ; 37.2\left(\mathrm{CH}_{2}\right) ; 36.5(\mathrm{C}) ; 31.8\left(\mathrm{CH}_{2}\right) ; 31.8\left(\mathrm{CH}_{2}\right) ; 31.7\left(\mathrm{CH}_{2}\right) ; 26.8$ $\left(\mathrm{CH}_{2}\right) ; 24.2\left(\mathrm{CH}_{2}\right) ; 21.1\left(\mathrm{CH}_{2}\right) ; 19.4\left(\mathrm{CH}_{3}\right) ; 18.9\left(\mathrm{CH}_{3}\right) ; 14.1\left(\mathrm{CH}_{3}, \mathrm{O}-\mathrm{CH}_{2}-\mathrm{CH}_{3}\right) ; 12.2\left(\mathrm{CH}_{2}, \mathrm{C} 18-\mathrm{H}\right)$. IR u $\max$ $3335(\mathrm{~N}-\mathrm{H}), 3033(=\mathrm{C}-\mathrm{H}), 2940(-\mathrm{C}-\mathrm{H}), 1750(\mathrm{C}=\mathrm{O}), 1740(\mathrm{C}=\mathrm{O}) \mathrm{cm}^{-1}$. HRMS calculated mass for $\mathrm{C}_{30} \mathrm{H}_{47} \mathrm{~N}_{4} \mathrm{O}_{4}\left(\mathrm{M}+\mathrm{H}^{+}\right)$527.3592; found $\mathrm{m} / \mathrm{z} 527.3598$.

4.2.9.3. Synthesis of $(3 \mathrm{~S}, 8 \mathrm{~S}, 9 \mathrm{~S}, 10 \mathrm{R}, 13 \mathrm{~S}, 14 \mathrm{~S}, 17 \mathrm{~S})-10,13-$ dimethyl-17-((R)-1-((1-octyl-1H-1,2,3triazol-4-yl)methyl)amino)ethyl)-2,3,4,7,8,9,10,11,12,13,14,15,16,17-tetradecahydro-1Hcyclopenta[a]phenanthren-3-yl acetate (C3)

Following the general reaction conditions for CuAAC reaction, the reaction was worked up and purified to afford $53 \mathrm{mg}$ of a light-yellow solid (isolated yield: $76 \%) .{ }^{1} \mathrm{H}$ NMR $\left(300 \mathrm{MHz}, \mathrm{CDCl}_{3}\right) \delta 7.41(\mathrm{~s}, 1 \mathrm{H}$, $\left.\mathrm{C}_{\text {triazole }} \mathrm{e}-\mathrm{H}\right) ; 5.34(\mathrm{~d}, 1 \mathrm{H}, J=5.0 \mathrm{~Hz}, \mathrm{C} 6-\mathrm{H}) ; 4.68-4.47(\mathrm{~m}, 1 \mathrm{H}, \mathrm{C} 3-\mathrm{H}) ; 4.30(\mathrm{t}, 2 \mathrm{H}, J=7.2$ $\mathrm{Hz}, \mathrm{N} 1$ triazole- $\mathrm{CH}_{2}$ ); 3.98 (d, $\left.1 \mathrm{H}, J=13.6 \mathrm{~Hz}, \mathrm{NH}-\mathrm{CH}_{2-}\right) ; 3.75\left(\mathrm{~d}, 1 \mathrm{H}, J=13.6 \mathrm{~Hz} ; \mathrm{NH}^{-} \mathrm{CH}_{2-}\right.$ ); $2.63(\mathrm{dd}, 1 \mathrm{H}, J=9.4,6.1 \mathrm{~Hz}, \mathrm{C} 20-\mathrm{H}) ; 2.29(\mathrm{~m}, 2 \mathrm{H}, J=7.4 \mathrm{~Hz}, \mathrm{C} 4-\mathrm{H}) ; 2.00(\mathrm{~s}, 3 \mathrm{H}$, $\left.\mathrm{COCH}_{3}\right) ; 1.99-1.68(\mathrm{~m}, 10 \mathrm{H}) ; 1.47(\mathrm{~m}, 7 \mathrm{H}) ; 1.26\left(\mathrm{~m}, 14 \mathrm{H},-\mathrm{CH}_{2}-\right) ; 1.17-0.90(\mathrm{~m}, 11 \mathrm{H})$; $0.90-0.79(\mathrm{~m}, 4 \mathrm{H}) ; 0.63(\mathrm{~s}, 3 \mathrm{H}, \mathrm{C} 18-\mathrm{H}) .{ }^{13} \mathrm{C} \mathrm{NMR}\left(75 \mathrm{MHz}, \mathrm{CDCl}_{3}\right) \delta 170.5(\mathrm{C}=\mathrm{O}) ; 147.0$ (C, C4 $\left.4_{\text {triazole }}\right) ; 139.6(\mathrm{C}, \mathrm{C} 5) ; 122.5(\mathrm{CH}, \mathrm{C} 6) ; 121.3\left(\mathrm{CH}, \mathrm{C}_{\text {triazole }}\right) ; 73.9(\mathrm{CH}, \mathrm{C} 3) ; 56.3(\mathrm{CH})$; $56.2(\mathrm{CH}) ; 55.2(\mathrm{CH}) ; 50.2\left(\mathrm{CH}_{2}, \mathrm{~N} 1_{\text {triazole }}-\mathrm{CH}_{2}\right) ; 49.9(\mathrm{CH}) ; 42.1(\mathrm{C}) ; 41.8\left(\mathrm{CH}_{2}, \mathrm{NH}-\mathrm{CH}_{2}\right)$; $40.0\left(\mathrm{CH}_{2}\right) ; 38.1\left(\mathrm{CH}_{2}\right) ; 37.0\left(\mathrm{CH}_{2}\right) ; 36.6(\mathrm{C}) ; 31.8\left(\mathrm{CH}_{2}\right) ; 31.7\left(\mathrm{CH}_{2}\right) ; 31.7\left(\mathrm{CH}_{2}\right) ; 30.3$ $\left(\mathrm{CH}_{2}\right) ; 29.1\left(\mathrm{CH}_{2}\right) ; 29.0\left(\mathrm{CH}_{2}\right) ; 27.7\left(\mathrm{CH}_{2}\right) ; 26.8\left(\mathrm{CH}_{2}\right) ; 26.5\left(\mathrm{CH}_{2}\right) ; 24.1\left(\mathrm{CH}_{2}\right) ; 22.6\left(\mathrm{CH}_{2}\right)$; $21.4\left(\mathrm{CH}_{2}\right) ; 21.1\left(\mathrm{CH}_{2}\right) ; 19.3\left(\mathrm{CH}_{3}\right) ; 19.0\left(\mathrm{CH}_{3}\right) ; 14.1\left(\mathrm{CH}_{2}\right.$, heptyl- $\left.\mathrm{CH}_{2}\right) ; 12.2\left(\mathrm{CH}_{3}\right)$. IR u $\max$ $3430(\mathrm{~N}-\mathrm{H})$; $3021(=\mathrm{C}-\mathrm{H}), 2924(-\mathrm{C}-\mathrm{H}), 2850(-\mathrm{C}-\mathrm{H}), 1750$ (C=O), 1631 (-C=C-), $1456 \mathrm{~cm}^{-1}$. HRMS calculated mass for $\mathrm{C}_{34} \mathrm{H}_{57} \mathrm{~N}_{4} \mathrm{O}_{2}\left(\mathrm{M}+\mathrm{H}^{+}\right)$553.4476; found m/z 553.4473.

4.2.9.4. Synthesis of $(3 S, 8 S, 9 S, 10 R, 13 S, 14 S, 17 S)-17-((R)-1-(((1-((E)-3,7-d i m e t h y l o c t a-2,6-d i e n-1-$ yl)-1H-1,2,3-triazol-4-yl)methyl)amino)ethyl)-10,13-dimethyl-2,3,4,7,8,9,10,11,12,13,14,15,16,17tetradecahydro-1H-cyclopenta[a]phenanthren-3-yl acetate (C4) 
Following the general reaction conditions for CUAAC reaction, the reaction was worked up and purified to afford $58 \mathrm{mg}$ of a light-yellow solid (isolated yield: $80 \%) .{ }^{1} \mathrm{H}$ NMR $\left(300 \mathrm{MHz}, \mathrm{CDCl}_{3}\right) \delta 7.39(\mathrm{~s}, 1 \mathrm{H}$, $\left.\mathrm{C}_{\text {triazole }} \mathrm{E}-\mathrm{H}\right) ; 7.38\left(\mathrm{~s}, 1 \mathrm{H}, \mathrm{C} 5_{\text {triazole }} \mathrm{Z}-\mathrm{H}\right) ; 5.39(\mathrm{~m}, 1 \mathrm{H},-\mathrm{CH}=\mathrm{C}) ; 5.34(\mathrm{~d}, 1 \mathrm{H}, J=5.0 \mathrm{~Hz}, \mathrm{C} 6-\mathrm{H})$ $5.15-5.00(\mathrm{~m}, 1 \mathrm{H},-\mathrm{CH}=\mathrm{C}) ; 4.91\left(\mathrm{t}, 2 \mathrm{H}, J=6.7 \mathrm{~Hz}, \mathrm{~N} 1_{\text {triazole }}-\mathrm{CH} 2-\right) ; 4.57(\mathrm{~m}, 1 \mathrm{H}, \mathrm{C} 3-\mathrm{H})$; $3.96\left(\mathrm{~d}, 1 \mathrm{H}, J=13.5 \mathrm{~Hz}, \mathrm{NH}-\mathrm{CH}_{2-}\right) ; 3.73\left(\mathrm{~d}, 1 \mathrm{H}, J=13.5 \mathrm{~Hz}, \mathrm{NH}-\mathrm{CH}_{2}-\right)$; $2.64(\mathrm{~m}, 1 \mathrm{H}, \mathrm{C} 20-$ $\mathrm{H}) ; 2.29(\mathrm{~d}, 2 \mathrm{H}, J=7.3 \mathrm{~Hz}, \mathrm{C} 4-\mathrm{H}) ; 2.04(\mathrm{~m}, 9 \mathrm{H}) ; 2.01\left(\mathrm{~s}, 3 \mathrm{H}, \mathrm{COCH}_{3}\right) ; 1.89-1.63(\mathrm{~m}$, $11 \mathrm{H}) ; 1.63-1.12(\mathrm{~m}, 25 \mathrm{H}) ; 1.12-0.91(\mathrm{~m}, 14 \mathrm{H}) ; 0.91-0.74(\mathrm{~m}, 6 \mathrm{H}) ; 0.64(\mathrm{~s}, 3 \mathrm{H}, \mathrm{C} 18-\mathrm{H})$. ${ }^{13} \mathrm{C}$ NMR $\left(75 \mathrm{MHz}, \mathrm{CDCl}_{3}\right) \delta 170.5(\mathrm{C}=\mathrm{O}) ; 147.1$ (C, C4 $\left.4_{\text {triazole }}\right) ; 143.0(\mathrm{C}, \mathrm{C}=\mathrm{CH}) ; 142.8(\mathrm{C}$, $\mathrm{C}=\mathrm{CH}) ; 139.6(\mathrm{C}, \mathrm{C} 5) ; 132.6(\mathrm{C}, \mathrm{C}=\mathrm{CH}) ; 132.1(\mathrm{C}, \mathrm{C}=\mathrm{CH}) ; 130.9(\mathrm{CH}, \mathrm{C}=\mathrm{CH}) ; 128.8(\mathrm{CH}$, $\mathrm{C}=\mathrm{CH}) ; 123.4(\mathrm{CH}, \mathrm{C}=\mathrm{CH}) ; 122.5(\mathrm{CH}, \mathrm{C} 6) ; 120.8\left(\mathrm{CH}, \mathrm{C}_{\text {triazole }}\right) ; 118.0(\mathrm{CH}, \mathrm{C}=\mathrm{CH}) ; 117.1$ $(\mathrm{CH}, \mathrm{C}=\mathrm{CH}) ; 73.9(\mathrm{CH}, \mathrm{C} 3) ; 56.3(\mathrm{CH}) ; 56.2(\mathrm{CH}) ; 55.2(\mathrm{CH}) ; 49.9(\mathrm{CH}) ; 47.8\left(\mathrm{CH}_{2}\right.$, $\left.\mathrm{N} 1_{\text {triazole }}-\mathrm{CH}_{2-}\right) ; 42.1\left(\mathrm{CH}_{2}, \mathrm{~N} 1_{\text {triazole }}-\mathrm{CH}_{2-}\right) ; 41.8\left(\mathrm{CH}_{2}, \mathrm{NH}-\mathrm{CH}_{2}\right) ; 40.0\left(\mathrm{CH}_{2}\right) ; 39.4\left(\mathrm{CH}_{2}\right) ; 38.1$ $\left(\mathrm{CH}_{2}\right) ; 36.9\left(\mathrm{CH}_{2}\right) ; 36.6(\mathrm{C}) ; 31.8\left(\mathrm{CH}_{2}\right) ; 31.7\left(\mathrm{CH}_{2}\right) ; 26.8\left(\mathrm{CH}_{2}\right) ; 26.2\left(\mathrm{CH}_{2}\right) ; 25.7\left(\mathrm{CH}_{3}\right)$; $24.1\left(\mathrm{CH}_{2}\right) ; 23.4\left(\mathrm{CH}_{3}\right) ; 21.4\left(\mathrm{CH}_{2}\right) ; 21.0\left(\mathrm{CH}_{2}\right) ; 19.3\left(\mathrm{CH}_{3}\right) ; 19.1\left(\mathrm{CH}_{3}\right) ; 19.0\left(\mathrm{CH}_{3}\right) ; 17.7$ $\left(\mathrm{CH}_{3}\right) ; 16.4\left(\mathrm{CH}_{3}\right) ; 12.2\left(\mathrm{CH}_{3}\right)$. IR $v_{\max } 3380(\mathrm{~N}-\mathrm{H}), 3055(=\mathrm{C}-\mathrm{H}), 2954(-\mathrm{C}-\mathrm{H}), 1744(\mathrm{C}=\mathrm{O})$, $1451 \mathrm{~cm}^{-1}$. HRMS calculated mass for $\mathrm{C}_{36} \mathrm{H}_{57} \mathrm{~N}_{4} \mathrm{O}_{2}\left(\mathrm{M}+\mathrm{H}^{+}\right)$577.4476; found m/z 577.4479.

4.2.9.5. Synthesis of $(3 \mathrm{~S}, 8 \mathrm{~S}, 9 \mathrm{~S}, 10 \mathrm{R}, 13 \mathrm{~S}, 14 \mathrm{~S}, 17 \mathrm{~S})-10,13-$ dimethyl-17-((R)-1-(((1-(3-phenylpropyl)1H-1,2,3-triazol-4-yl)methyl)amino)ethyl)-2,3,4,7,8,9,10,11,12,13,14,15,16,17-tetradecahydro-1Hcyclopenta[a]phenanthren-3-yl acetate (C5)

Following the general reaction conditions for CuAAC reaction, the reaction was worked up and purified to afford $60 \mathrm{mg}$ of a light-yellow solid (isolated yield: $85 \%) .{ }^{1} \mathrm{H}$ NMR $\left(300 \mathrm{MHz}, \mathrm{CDCl}_{3}\right) \delta 7.49(\mathrm{~s}, 1 \mathrm{H}$, $\left.\mathrm{C5}_{\text {triazole- }} \mathrm{H}\right) ; 7.36$ - 7.24 (m, 2H, m-aromatic); 7.24 - $7.09(\mathrm{~m}, 3 \mathrm{H}, p$-and o-aromatic); 5.40 $5.30(\mathrm{~m}, 1 \mathrm{H}, \mathrm{C} 6-\mathrm{H}) ; 4.69-4.51(\mathrm{~m}, 1 \mathrm{H}, \mathrm{C} 3-\mathrm{H}) ; 4.32\left(\mathrm{t}, 2 \mathrm{H}, \mathrm{J}=7.1 \mathrm{~Hz}, \mathrm{~N}_{\text {triazole- }} \mathrm{CH}_{2^{-}}\right) ; 4.01$ $\left(\mathrm{d}, 1 \mathrm{H}, J=13.7 \mathrm{~Hz}, \mathrm{NH}-\mathrm{CH}_{2^{-}}\right) ; 3.81\left(\mathrm{~d}, 1 \mathrm{H}, J=13.6 \mathrm{~Hz}, \mathrm{NH}-\mathrm{CH}_{2^{-}}\right) ; 2.63(\mathrm{t}, 2 \mathrm{H}, \mathrm{J}=7.5 \mathrm{~Hz}$, $\mathrm{CH}_{2}$-phenyl); $2.57(\mathrm{~m}, 1 \mathrm{H}, \mathrm{C} 20-\mathrm{H}) ; 2.38-2.11(\mathrm{~m}, 4 \mathrm{H}) ; 2.01\left(\mathrm{~s}, 3 \mathrm{H}, \mathrm{COCH}_{3}\right) ; 1.84(\mathrm{~m}, 5 \mathrm{H})$; $1.73-1.29(\mathrm{~m}, 9 \mathrm{H}) ; 1.29-0.80(\mathrm{~m}, 13 \mathrm{H}) ; 0.65(\mathrm{~s}, 3 \mathrm{H}, \mathrm{C} 18-\mathrm{H}) .{ }^{13} \mathrm{C} \mathrm{NMR}\left(75 \mathrm{MHz}, \mathrm{CDCl}_{3}\right)$ ठ 170.5 (C=O); 146.5 (C, C4triazole); 140.2 (C, ipso-aromatic); 139.6 (C, C5); 128.6 (CH, maromatic); 128.4 (CH, o-aromatic); $126.3(\mathrm{CH}, p$-aromatic); $122.5(\mathrm{CH}, \mathrm{C6}) ; 121.8(\mathrm{CH}$, $\left.\mathrm{C5}_{\text {triazole }}\right) ; 73.9(\mathrm{CH}, \mathrm{C} 3) ; 56.5(\mathrm{CH}) ; 56.1(\mathrm{CH}) ; 55.9(\mathrm{CH}) ; 49.9(\mathrm{CH}) ; 49.5\left(\mathrm{CH}_{2}-\right.$ phenyl); $42.0\left(\mathrm{CH}_{2}\right) ; 41.4\left(\mathrm{NH}-\mathrm{CH}_{2}\right) ; 39.2\left(\mathrm{CH}_{2}\right) ; 38.1\left(\mathrm{CH}_{2}\right) ; 37.0\left(\mathrm{CH}_{2}\right) ; 36.6(\mathrm{C}) ; 32.5\left(\mathrm{~N}_{\text {triazole- }}\right.$ $\left.\mathrm{CH}_{2}\right) ; 31.8\left(\mathrm{CH}_{2}\right) ; 31.7\left(\mathrm{CH}_{2}\right) ; 27.7\left(\mathrm{CH}_{2}\right) ; 27.1\left(\mathrm{CH}_{2}\right) ; 24.1\left(\mathrm{CH}_{2}\right) ; 21.4\left(\mathrm{CH}_{2}\right) ; 20.9\left(\mathrm{CH}_{2}\right)$; $19.3\left(\mathrm{CH}_{3}\right) ; 18.8\left(\mathrm{CH}_{3}\right) ; 12.2\left(\mathrm{CH}_{3}\right)$. IR $u_{\max } 3400(\mathrm{~N}-\mathrm{H}), 3015(=\mathrm{C}-\mathrm{H}), 2862(-\mathrm{C}-\mathrm{H}), 1750$ $(\mathrm{C}=\mathrm{O}), 1451 \mathrm{~cm}^{-1}$. HRMS calculated mass for $\mathrm{C}_{35} \mathrm{H}_{51} \mathrm{~N}_{4} \mathrm{O}_{2}\left(\mathrm{M}+\mathrm{H}^{+}\right) 559.4007$; found $\mathrm{m} / \mathrm{z}$ 559.4012 .

4.2.9.6. Synthesis of $\quad(3 \mathrm{~S}, 8 \mathrm{~S}, 9 \mathrm{~S}, 10 \mathrm{R}, 13 \mathrm{~S}, 14 \mathrm{~S}, 17 \mathrm{~S})-17-((\mathrm{S})-1-(((1-$ benzyl-1H-1,2,3-triazol-4yl)methyl)amino)ethyl)-10,13-dimethyl-2,3,4,7,8,9,10,11,12,13,14,15,16,17-tetradecahydro-1Hcyclopenta[a]phenanthren-3-yl acetate (D1) 
Following the general reaction conditions for CUAAC reaction, the reaction was worked up and purified to afford $55 \mathrm{mg}$ of a light-yellow solid (isolated yield: $83 \%) .{ }^{1} \mathrm{H}$ NMR $\left(300 \mathrm{MHz}, \mathrm{CDCl}_{3}\right) \delta 7.76(\mathrm{~s}, 1 \mathrm{H}$, $\mathrm{C}_{\text {triazole- }} \mathrm{H}$ ); 7.32 (m, 3H, p-and m-aromatics); 7.23 (m, 2H, o-aromatics); 5.50 (s, 2H, $\mathrm{CH}_{2}-$ phenyl); $5.34(\mathrm{~d}, 1 \mathrm{H}, J=4.1 \mathrm{~Hz}, \mathrm{C} 6-\mathrm{H}) ; 4.57(\mathrm{~m}, 1 \mathrm{H}, \mathrm{C} 3-\mathrm{H}) ; 4.18(\mathrm{~d}, 1 \mathrm{H}, J=13.8 \mathrm{~Hz}, \mathrm{NH}-$ $\mathrm{CH}_{2}$ ); 3.97 (d, 1H, J = $13.8 \mathrm{~Hz}, \mathrm{NH}-\mathrm{CH}_{2}$ ); 2.78 (dd, 1H, J = 10.3, $\left.6.2 \mathrm{~Hz}, \mathrm{C} 20-\mathrm{H}\right) ; 2.30$ (d, $2 \mathrm{H}, J=7.5 \mathrm{~Hz}, \mathrm{C} 4-\mathrm{H}) ; 2.01$ (s, 3H, $\left.\mathrm{CH}_{3} \mathrm{CO}-\right) ; 1.98-1.71(\mathrm{~m}, 7 \mathrm{H}) ; 1.71-1.34(\mathrm{~m}, 7 \mathrm{H}) ; 1.35$ $-0.72(\mathrm{~m}, 13 \mathrm{H}) ; 0.59(\mathrm{~s}, 3 \mathrm{H}, \mathrm{C} 18-\mathrm{H}) .{ }^{13} \mathrm{C}$ NMR (75 MHz, $\left.\mathrm{CDCl}_{3}\right) \delta 170.5(\mathrm{C}=\mathrm{O}) ; 143.1$ (C, C4triazole); 139.6 (C, C5); 134.6 (C, ipso-aromatic); 129.1 (CH, p-aromatic); 128.7 (CH, maromatic); $128.0\left(\mathrm{CH}\right.$, o-aromatic); $123.7\left(\mathrm{CH}, \mathrm{C}_{\text {triazole }}\right) ; 122.3(\mathrm{CH}, \mathrm{C} 6) ; 73.9(\mathrm{CH}, \mathrm{C} 3)$; $56.3(\mathrm{CH}) ; 55.9(\mathrm{CH}) ; 54.5(\mathrm{CH}) ; 54.2\left(\mathrm{CH} 2, \mathrm{CH}_{2}-\right.$ phenyl); $49.8(\mathrm{CH}) ; 42.3\left(\mathrm{CH}_{2}\right) ; 39.6$ $\left(\mathrm{CH}_{2}\right) ; 39.1\left(\mathrm{CH}_{2}\right) ; 38.0\left(\mathrm{CH}_{2}\right) ; 36.9(\mathrm{C}) ; 36.5(\mathrm{C}) ; 31.7\left(\mathrm{CH}_{2}\right) ; 31.6(\mathrm{CH}) ; 27.7\left(\mathrm{CH}_{2}\right) ; 27.0$ $\left(\mathrm{CH}_{2}\right) ; 24.2\left(\mathrm{CH}_{2}\right) ; 21.4\left(\mathrm{COCH}_{3}\right) ; 20.8\left(\mathrm{CH}_{2}\right) ; 19.3\left(\mathrm{CH}_{3}\right) ; 17.2\left(\mathrm{CH}_{3}\right) ; 12.0\left(\mathrm{CH}_{3}\right)$. IR u $\max$ $3340(\mathrm{~N}-\mathrm{H}), 3014(=\mathrm{C}-\mathrm{H}), 2940(-\mathrm{C}-\mathrm{H}), 2878(-\mathrm{C}-\mathrm{H}), 1757(\mathrm{C}=\mathrm{O}), 1689 \mathrm{~cm}^{-1}$. HRMS calculated mass for $\mathrm{C}_{33} \mathrm{H}_{47} \mathrm{~N}_{4} \mathrm{O}_{2}\left(\mathrm{M}+\mathrm{H}^{+}\right)$531.3694; found $\mathrm{m} / \mathrm{z}$ 531.3694.

4.2.9.7. Synthesis of ethyl 2-(4-(((S)-1-((3S,8S,9S,10R,13S,14S,17S)-3-acetoxy-10,13-dimethyl2,3,4,7,8,9,10,11,12,13,14,15,16,17-tetradecahydro-1H-cyclopenta[a]phenanthren-17-

yl)ethyl)amino)methyl)-1H-1,2,3-triazol-1-yl)acetate (D2)

Following the general reaction conditions for CuAAC reaction, the reaction was worked up and purified to afford $46 \mathrm{mg}$ of a light-yellow solid (isolated yield: $70 \%) .{ }^{1} \mathrm{H}$ NMR $\left(300 \mathrm{MHz}, \mathrm{CDCl}_{3}\right) \delta 7.61(\mathrm{~s}, 1 \mathrm{H}$, $\mathrm{C}_{\text {triazole-H) }}$; 5.36 (d, 1H, J = 5.0 Hz, C6-H); 5.12 (d, 2H, J = 1.3 Hz, -CH2-COOEt); 4.59 (m, $1 \mathrm{H}, \mathrm{C} 3-\mathrm{H}) ; 4.25$ (q, 2H, J=7.1 Hz, O- $\mathrm{CH}_{2^{-}}$); 4.01 (d, $1 \mathrm{H}, J=13.8 \mathrm{~Hz}, \mathrm{NH}_{-} \mathrm{CH}_{2^{-}}$); 3.82 (d, $\left.1 \mathrm{H}, J=13.8 \mathrm{~Hz}, \mathrm{NH}-\mathrm{CH}_{2-}\right) ; 2.60(\mathrm{~m}, 1 \mathrm{H}, \mathrm{C} 20-\mathrm{H}) ; 2.30(\mathrm{~m}, 2 \mathrm{H}, \mathrm{C} 4-\mathrm{H}) ; 2.22-1.74(\mathrm{~m}, 9 \mathrm{H})$; $2.01\left(\mathrm{~s}, 3 \mathrm{H},-\mathrm{COCH}_{3}\right) 1.73-1.23(\mathrm{~m}, 13 \mathrm{H}) ; 1.23-0.86(\mathrm{~m}, 12 \mathrm{H}) ; 0.66(\mathrm{~s}, 3 \mathrm{H}, \mathrm{C} 18-\mathrm{H}) .{ }^{13} \mathrm{C}$ NMR (75 MHz, $\left.\mathrm{CDCl}_{3}\right) \delta 170.5(\mathrm{C}=\mathrm{O}) ; 166.3(\mathrm{C}=\mathrm{O}) ; 147.4$ (C, C4 $\left.4_{\text {triazole }}\right) ; 139.6$ (C, C5); $123.1(\mathrm{CH}, \mathrm{C} 5$ triazole $) ; 122.5(\mathrm{CH}, \mathrm{C} 6) ; 73.9(\mathrm{CH}, \mathrm{C} 3) ; 62.4\left(\mathrm{CH}_{2},-\mathrm{OCH}_{2-}\right) ; 56.5(\mathrm{CH}) ; 56.3$ $(\mathrm{CH}) ; 55.9(\mathrm{CH}) ; 50.9\left(\mathrm{CH} 2, \mathrm{~N} 11_{\text {triazole }}-\mathrm{CH}_{2}\right) ; 49.9(\mathrm{CH}) ; 42.0\left(\mathrm{CH}_{2}\right) ; 41.5\left(\mathrm{NH}-\mathrm{CH}_{2}\right) ; 39.2$ $\left(\mathrm{CH}_{2}\right) ; 38.1\left(\mathrm{CH}_{2}\right) ; 37.0\left(\mathrm{CH}_{2}\right) ; 36.6(\mathrm{C}) ; 31.8\left(\mathrm{CH}_{2}\right) ; 31.7\left(\mathrm{CH}_{2}\right) ; 27.7\left(\mathrm{CH}_{2}\right) ; 27.1\left(\mathrm{CH}_{2}\right)$; $24.1\left(\mathrm{CH}_{2}\right) ; 21.4\left(\mathrm{CH}_{2}\right) ; 20.9\left(\mathrm{CH}_{2}\right) ; 19.3\left(\mathrm{CH}_{3}\right) ; 19.0\left(\mathrm{CH}_{3}\right) ; 14.1\left(\mathrm{CH}_{3}, \mathrm{O}-\mathrm{CH}_{2}-\mathrm{CH}_{3}\right) ; 12.2$ $\left(\mathrm{CH}_{3}\right)$. IR $u_{\max } 3401(\mathrm{~N}-\mathrm{H}), 3045(=\mathrm{C}-\mathrm{H}), 2986(-\mathrm{C}-\mathrm{H}), 1754(\mathrm{C}=\mathrm{O}), 1745(\mathrm{C}=\mathrm{O}) \mathrm{cm}^{-1}$. HRMS calculated mass for $\mathrm{C}_{30} \mathrm{H}_{47} \mathrm{~N}_{4} \mathrm{O}_{4}\left(\mathrm{M}+\mathrm{H}^{+}\right)$527.3592; found $\mathrm{m} / \mathrm{z}$ 527.3595.

4.2.9.8. Synthesis of $(3 \mathrm{~S}, 8 \mathrm{~S}, 9 \mathrm{~S}, 10 \mathrm{R}, 13 \mathrm{~S}, 14 \mathrm{~S}, 17 \mathrm{~S})-10,13-$ dimethyl-17-((S)-1-((1-octyl-1H-1,2,3triazol-4-yl)methyl)amino)ethyl)-2,3,4,7,8,9,10,11,12,13,14,15,16,17-tetradecahydro-1Hcyclopenta[a]phenanthren-3-yl acetate (D3)

Following the general reaction conditions for CuAAC reaction, the reaction was worked up and purified to afford $56 \mathrm{mg}$ of a light-yellow solid (isolated yield: $81 \%) .{ }^{1} \mathrm{H} \mathrm{NMR}\left(300 \mathrm{MHz}, \mathrm{CDCl}_{3}\right) \delta 7.79(\mathrm{~s}, 1 \mathrm{H}$, C5 triazole-H); 5.34 (d, 1H, J = 4.9 Hz, C6-H); 4.58 (dd, J = 6.5, $4.1 \mathrm{~Hz}, 1 \mathrm{H}, \mathrm{C} 3-\mathrm{H}) ; 4.32(\mathrm{t}, J=$ $\left.7.2 \mathrm{~Hz}, 2 \mathrm{H}, \mathrm{N} 1_{\text {triazole }}-\mathrm{CH}_{2-}\right) ; 4.22\left(\mathrm{~d}, 1 \mathrm{H}, J=13.8 \mathrm{~Hz}, \mathrm{NH}-\mathrm{CH}_{2}\right) ; 3.99(\mathrm{~d}, J=13.8 \mathrm{~Hz}, 1 \mathrm{H}, \mathrm{NH}-$ 
$\left.\mathrm{CH}_{2}\right) ; 2.81(\mathrm{~m}, 1 \mathrm{H}, \mathrm{C} 20-\mathrm{H}) ; 2.30(\mathrm{~m}, 2 \mathrm{H}, \mathrm{C} 4-\mathrm{H}) ; 2.01\left(\mathrm{~s}, 3 \mathrm{H}, \mathrm{COCH}_{3}\right) ; 2.00-1.74(\mathrm{~m}, 10 \mathrm{H})$; $1.74-1.37(\mathrm{~m}, 8 \mathrm{H}) ; 1.37-1.13(\mathrm{~m}, 18 \mathrm{H}) ; 0.99(\mathrm{~m}, 4 \mathrm{H}) ; 0.83(\mathrm{t}, 3 \mathrm{H}, \mathrm{J}=6.6 \mathrm{~Hz}$, heptyl$\mathrm{CH} 3) ; 0.62$ (s, 3H, C18-H). ${ }^{13} \mathrm{C}$ NMR (75 MHz, $\left.\mathrm{CDCl}_{3}\right) \delta 170.5(\mathrm{C}=\mathrm{O}) ; 139.6$ (C, C4triazole); 139.6 (C, C5); $123.0\left(\mathrm{CH}, \mathrm{C}_{\text {triazole }}\right) ; 122.4(\mathrm{CH}, \mathrm{C} 6) ; 73.9(\mathrm{CH}, \mathrm{C} 3) ; 56.4(\mathrm{CH}) ; 56.0(\mathrm{CH})$; $54.9(\mathrm{CH}) ; 50.4\left(\mathrm{CH} 2, \mathrm{~N} 1_{\text {triazole }}-\mathrm{CH}_{2}\right)$; $49.8\left(\mathrm{CH}_{2}\right) ; 42.2(\mathrm{C}) ; 40.2\left(\mathrm{NH}_{-} \mathrm{CH}_{2}\right) ; 39.1\left(\mathrm{CH}_{2}\right) ; 38.1$ $\left(\mathrm{CH}_{2}\right) ; 37.0\left(\mathrm{CH}_{2}\right) ; 36.5(\mathrm{C}) ; 31.7\left(\mathrm{CH}_{2}\right) ; 30.3\left(\mathrm{CH}_{2}\right) ; 29.1\left(\mathrm{CH}_{2}\right) ; 29.0\left(\mathrm{CH}_{2}\right) ; 27.7\left(\mathrm{CH}_{2}\right)$; $27.1\left(\mathrm{CH}_{2}\right) ; 26.5\left(\mathrm{CH}_{2}\right) ; 24.2\left(\mathrm{CH}_{2}\right) ; 22.6\left(\mathrm{CH}_{2}\right) ; 21.4\left(\mathrm{CH}_{2}\right) ; 20.8\left(\mathrm{CH}_{2}\right) ; 19.3\left(\mathrm{CH}_{3}\right) ; 17.7$ $\left(\mathrm{CH}_{3}\right) ; 14.1$ (heptyl- $\left.\mathrm{CH}_{3}\right) ; 12.1\left(\mathrm{CH}_{3}\right)$. IR $v_{\max } 3404(\mathrm{~N}-\mathrm{H}) ; 3011(=\mathrm{C}-\mathrm{H}), 2958(-\mathrm{C}-\mathrm{H}), 1748$ $(\mathrm{C}=\mathrm{O}), 1615,1458 \mathrm{~cm}^{-1}$. HRMS calculated mass for $\mathrm{C}_{34} \mathrm{H}_{57} \mathrm{~N}_{4} \mathrm{O}_{2}\left(\mathrm{M}+\mathrm{H}^{+}\right) 553.4476$; found m/z 553.4475.

4.2.9.9. Synthesis of $(3 \mathrm{~S}, 8 \mathrm{~S}, 9 \mathrm{~S}, 10 \mathrm{R}, 13 \mathrm{~S}, 14 \mathrm{~S}, 17 \mathrm{~S})-17-((\mathrm{S})-1-(((1-)(\mathrm{E})-3,7-$ dimethylocta-2,6-dien-1yl)-1H-1,2,3-triazol-4-yl)methyl)amino)ethyl)-10,13-dimethyl-2,3,4,7,8,9,10,11,12,13,14,15,16,17tetradecahydro-1H-cyclopenta[a]phenanthren-3-yl acetate (D4)

Following the general reaction conditions for CuAAC reaction, the reaction was worked up and purified to afford $64 \mathrm{mg}$ of a light-yellow solid (isolated yield: $88 \%) .{ }^{1} \mathrm{H}$ NMR $\left(300 \mathrm{MHz}, \mathrm{CDCl}_{3}\right) \delta 7.70(\mathrm{~s}, 1 \mathrm{H}$, $\mathrm{C}_{\text {triazole }}-\mathrm{H}$ ); 5.38 (t, $\left.1 \mathrm{H}, J=7.3 \mathrm{~Hz}, \mathrm{~N} 1_{\text {triazole }}-\mathrm{CH}_{2}-\mathrm{CH}=\mathrm{C}\right) ; 5.34(\mathrm{~d}, 1 \mathrm{H}, J=4.9 \mathrm{~Hz}, \mathrm{C} 6-\mathrm{H})$; $5.19-4.95(\mathrm{~m}, 1 \mathrm{H}, \mathrm{CH}=\mathrm{C}) ; 4.91\left(7, J=7.0 \mathrm{~Hz}, 2 \mathrm{H}, \mathrm{N} 1_{\text {triazole }}-\mathrm{CH}_{2^{-}}\right) ; 4.57(\mathrm{~m}, 1 \mathrm{H}, \mathrm{C} 3-\mathrm{H})$; $4.16\left(\mathrm{~d}, 1 \mathrm{H}, J=13.8 \mathrm{~Hz}, \mathrm{NH}-\mathrm{CH}_{2-}\right)$; $3.95\left(\mathrm{~d}, 1 \mathrm{H}, J=13.7 \mathrm{~Hz}, \mathrm{NH}-\mathrm{CH}_{2-}\right) ; 2.78(\mathrm{dd}, 1 \mathrm{H}, J=$ 10.3, 6.1 Hz, C20-H); 2.29 (d, 2H, J = 7.1 Hz, C4-H); $2.22-1.71(\mathrm{~m}, 12 \mathrm{H}) ; 2.01(\mathrm{~s}, 3 \mathrm{H}$, $\left.\mathrm{COCH}_{3}\right) 1.71-1.37(\mathrm{~m}, 14 \mathrm{H}) ; 1.37-0.79(\mathrm{~m}, 16 \mathrm{H}) ; 0.62(\mathrm{~s}, 3 \mathrm{H}, \mathrm{C} 18-\mathrm{H}) .{ }^{13} \mathrm{C}$ NMR $(75$ $\mathrm{MHz}_{\mathrm{CDCl}}$ ) $\delta 170.5(\mathrm{C}=\mathrm{O}) ; 143.2$ (C, C4triazole); $139.6(\mathrm{C}, \mathrm{C} 5) ; 132.6(\mathrm{C}, \mathrm{C}=\mathrm{CH}) ; 132.1(\mathrm{C}$, $\mathrm{C}=\mathrm{CH}) ; 123.4(\mathrm{C}, \mathrm{C}=\mathrm{CH}) ; 123.2\left(\mathrm{CH}, \mathrm{C} 5_{\text {triazole }}\right) ; 122.8(\mathrm{CH}, \mathrm{C} 6) ; 122.3(\mathrm{CH}, \mathrm{C}=\mathrm{CH}) ; 117.7$ $(\mathrm{CH}, \mathrm{C}=\mathrm{CH}) ; 116.9(\mathrm{CH}, \mathrm{C}=\mathrm{CH}) ; 73.8(\mathrm{CH}, \mathrm{C} 3) ; 56.4(\mathrm{CH}) ; 56.0(\mathrm{CH}) ; 54.9(\mathrm{CH}) ; 49.8$ $(\mathrm{CH}) ; 48.0\left(\mathrm{CH}_{2}\right) ; 47.8\left(\mathrm{CH}_{2}\right) ; 42.2(\mathrm{C}) ; 40.2\left(\mathrm{CH}_{2}\right) ; 39.4\left(\mathrm{CH}_{2}\right) ; 39.1\left(\mathrm{CH}_{2}\right) ; 38.0\left(\mathrm{CH}_{2}\right) ; 36.9$ $\left(\mathrm{CH}_{2}\right) ; 36.5(\mathrm{C}) ; 32.1\left(\mathrm{CH}_{2}\right) ; 31.7(\mathrm{CH}) ; 31.6\left(\mathrm{CH}_{2}\right) ; 27.7\left(\mathrm{CH}_{2}\right) ; 27.1\left(\mathrm{CH}_{2}\right) ; 26.3\left(\mathrm{CH}_{2}\right) ; 26.2$ $\left(\mathrm{CH}_{2}\right) ; 25.7\left(\mathrm{CH}_{3}\right) ; 24.2\left(\mathrm{CH}_{2}\right) ; 23.4\left(\mathrm{CH}_{3}\right) ; 21.4\left(\mathrm{CH}_{2}\right) ; 20.8\left(\mathrm{CH}_{2}\right) ; 19.3\left(\mathrm{CH}_{3}\right) ; 17.7\left(\mathrm{CH}_{3}\right)$; $17.6\left(\mathrm{CH}_{3}\right) ; 16.5\left(\mathrm{CH}_{3}\right) ; 12.0\left(\mathrm{CH}_{3}\right)$. IR $u_{\max } 3401(\mathrm{~N}-\mathrm{H}), 3045(=\mathrm{C}-\mathrm{H}), 2899(-\mathrm{C}-\mathrm{H}), 1750$ $(\mathrm{C}=\mathrm{O}), 1658$ (-C=C-), $1444 \mathrm{~cm}^{-1}$. HRMS calculated mass for $\mathrm{C}_{36} \mathrm{H}_{57} \mathrm{~N}_{4} \mathrm{O}_{2}\left(\mathrm{M}+\mathrm{H}^{+}\right) 577.4476$; found $\mathrm{m} / \mathrm{z} 577.4475$.

4.2.9.10. Synthesis of $(3 S, 8 S, 9 S, 10 R, 13 S, 14 S, 17 S)-10,13-d i m e t h y l-17-((S)-1-(((1-(3-p h e n y l p r o p y l)-$ 1H-1,2,3-triazol-4-yl)methyl)amino)ethyl)-2,3,4,7,8,9,10,11,12,13,14,15,16,17-tetradecahydro-1Hcyclopenta[a]phenanthren-3-yl acetate (D5)

Following the general reaction conditions for CuAAC reaction, the reaction was worked up and purified to afford $60 \mathrm{mg}$ of a light-yellow solid (isolated yield: $85 \%) .{ }^{1} \mathrm{H}$ NMR $\left(300 \mathrm{MHz}, \mathrm{CDCl}_{3}\right) \delta 7.49(\mathrm{~s}, 1 \mathrm{H}$, $\left.\mathrm{C5}_{\text {triazole }}-\mathrm{H}\right) ; 7.37$ - $7.24(\mathrm{~m}, 2 \mathrm{H}, m$-aromatic); $7.24-7.08(\mathrm{~m}, 3 \mathrm{H}, p$ - and o-aromatic); 5.35 (d, $1 \mathrm{H}, J=4.4 \mathrm{~Hz}, \mathrm{C} 6-\mathrm{H}) ; 4.70-4.49(\mathrm{~m}, 1 \mathrm{H}, \mathrm{C} 3-\mathrm{H}) ; 4.32\left(\mathrm{t}, 2 \mathrm{H}, J=7.1 \mathrm{~Hz}, \mathrm{~N} 1_{\text {triazole }}-\mathrm{CH}_{2}\right)$; $4.01\left(\mathrm{~d}, 1 \mathrm{H}, J=13.7 \mathrm{~Hz}, \mathrm{NH}-\mathrm{CH}_{2}\right) ; 3.81\left(\mathrm{~d}, 1 \mathrm{H}, J=13.7 \mathrm{~Hz}, \mathrm{NH}-\mathrm{CH}_{2-}\right) ; 2.63(\mathrm{t}, 2 \mathrm{H}, J=7.5$ 
$\mathrm{Hz}, \mathrm{CH}_{2}$-phenyl); 2.56 (m, 3H, C4-H, C20-H); 2.32 (m, 2H, C4-H); 2.22 (q, 2H, J = 7.2 Hz, $\left.\mathrm{N} 1_{\text {triazole }}-\mathrm{CH}_{2}-\mathrm{CH}_{2}-\right) ; 2.01\left(\mathrm{~s}, 3 \mathrm{H}, \mathrm{COCH}_{3}\right) ; 1.99-1.73(\mathrm{~m}, 5 \mathrm{H}) ; 1.73-1.27(\mathrm{~m}, 8 \mathrm{H}) ; 1.27-$ $\left.0.81(\mathrm{~m}, 11 \mathrm{H}) ; 0.65(\mathrm{~s}, 3 \mathrm{H}, \mathrm{C} 18-\mathrm{H}) .{ }^{13} \mathrm{C} \mathrm{NMR} \mathrm{(75} \mathrm{MHz,} \mathrm{CDCl}_{3}\right) \delta 170.5(\mathrm{C}=\mathrm{O}) ; 146.5(\mathrm{C}$, C4triazole); 140.2 (C, ipso-aromatic); 139.6 (C, C5); 128.6 (CH, m-aromatic); 128.4 (CH, oaromatic); $126.3\left(\mathrm{CH}, p\right.$-aromatic); $122.5(\mathrm{CH}, \mathrm{C} 6) ; 121.8\left(\mathrm{CH}, \mathrm{C} 5_{\text {triazole }}\right) ; 73.9(\mathrm{CH}, \mathrm{C} 3)$; $56.5(\mathrm{CH}) ; 56.1(\mathrm{CH}) ; 55.9(\mathrm{CH}) ; 49.9(\mathrm{CH}) ; 49.5 \mathrm{CH}_{2}, \mathrm{CH}_{2}-$ phenyl); $42.0\left(\mathrm{CH}_{2}, \mathrm{NH}-\mathrm{CH}_{2-}\right)$; $41.4(\mathrm{C}) ; 39.2\left(\mathrm{CH}_{2}\right) ; 38.1\left(\mathrm{CH}_{2}\right) ; 37.0\left(\mathrm{CH}_{2}\right) ; 36.6(\mathrm{C}) ; 32.5\left(\mathrm{~N} 1_{\text {triazole }}-\mathrm{CH}_{2}\right) ; 31.8\left(\mathrm{CH}_{2}\right) ; 31.7$ $\left(\mathrm{CH}_{2}\right) ; 27.7\left(\mathrm{CH}_{2}\right) ; 27.1\left(\mathrm{CH}_{2}\right) ; 24.1\left(\mathrm{CH}_{2}\right) ; 21.4\left(\mathrm{CH}_{2}\right) ; 20.9\left(\mathrm{CH}_{2}\right) ; 19.3\left(\mathrm{CH}_{3}\right) ; 18.8\left(\mathrm{CH}_{2}\right)$; $12.2\left(\mathrm{CH}_{2}\right)$. IR $u_{\max } 3400(\mathrm{~N}-\mathrm{H}), 3015(=\mathrm{C}-\mathrm{H}), 2920(-\mathrm{C}-\mathrm{H}), 1732(\mathrm{C}=\mathrm{O}), 1455 \mathrm{~cm}^{-1}$. HRMS calculated mass for $\mathrm{C}_{35} \mathrm{H}_{51} \mathrm{~N}_{4} \mathrm{O}_{2}\left(\mathrm{M}+\mathrm{H}^{+}\right)$559.4007; found $\mathrm{m} / \mathrm{z} 559.4012$.

4.2.9.11. Synthesis of $(3 \mathrm{~S}, 8 \mathrm{~S}, 9 \mathrm{~S}, 10 \mathrm{R}, 13 \mathrm{~S}, 14 \mathrm{~S}, 17 \mathrm{~S})-17-((R)-1-(((1-$ benzyl-1H-1,2,3-triazol-4yl)methyl)amino)-2-hydroxypropan-2-yl)-10,13-dimethyl-2,3,4,7,8,9,10,11,12,13,14,15,16,17tetradecahydro-1H-cyclopenta[a]phenanthren-3-ol (E1)

Following the general reaction conditions for CuAAC reaction, the reaction was worked up and purified to afford $53 \mathrm{mg}$ of a light-yellow solid (isolated yield: $79 \%) .{ }^{1} \mathrm{H} \mathrm{NMR}\left(300 \mathrm{MHz}, \mathrm{CDCl}_{3}\right) \delta 7.36(\mathrm{~m}$, $4 \mathrm{H}, \mathrm{C} 4_{\text {triazole }} \mathrm{H}, m$ - and $p$-aromatic); 7.27 (m, 2H, o-aromatic); 5.51 (s, 2H, $\mathrm{CH}_{2}$-phenyl); 5.41 - $5.29(\mathrm{~m}, 1 \mathrm{H}, \mathrm{C} 6-\mathrm{H}) ; 3.92\left(\mathrm{~s}, 2 \mathrm{H}, \mathrm{NH}-\mathrm{CH}_{2}\right.$-triazole); $3.63-3.38(\mathrm{~m}, 1 \mathrm{H}, \mathrm{C} 3-\mathrm{H}) ; 3.01-2.83$ $(\mathrm{m}, 1 \mathrm{H}) ; 2.54(\mathrm{~s}, 2 \mathrm{H}, \mathrm{C} 22-\mathrm{H}) ; 2.43-1.91(\mathrm{~m}, 12 \mathrm{H}) ; 1.83(\mathrm{~m}, 3 \mathrm{H}) ; 1.73-1.31(\mathrm{~m}, 11 \mathrm{H})$; $1.23(\mathrm{~m}, 7 \mathrm{H}) ; 1.03-0.61(\mathrm{~m}, 10 \mathrm{H}) .{ }^{13} \mathrm{C}$ NMR $\left(75 \mathrm{MHz}, \mathrm{CDCl}_{3}\right) \delta 140.8$ (C, C5); 134.7 (C, C4triazole); 129.1 (C, ipso-aromatic); 129.1 ( $\mathrm{CH}, \mathrm{m}$-aromatic); $128.8(\mathrm{CH}, \mathrm{p}$-aromatic); 128.0 $\left(\mathrm{CH}\right.$, o-aromatic); $121.6(\mathrm{CH}, \mathrm{C} 6) ; 121.6\left(\mathrm{CH}, \mathrm{C}_{\text {triazole }}\right) ; 73.1(\mathrm{C}, \mathrm{C} 20) ; 71.8(\mathrm{CH}, \mathrm{C} 3) ; 58.7$ $\left(\mathrm{CH}_{2}, \mathrm{C} 22\right) ; 57.5(\mathrm{CH}) ; 56.9(\mathrm{CH}) ; 54.2\left(\mathrm{CH}_{2}, \mathrm{CH}_{2}\right.$-phenyl); $52.3\left(\mathrm{CH}_{2}, \mathrm{NH}-\mathrm{CH}_{2}\right.$-triazole); $50.0(\mathrm{CH}) ; 42.7(\mathrm{C}) ; 42.3\left(\mathrm{CH}_{2}\right) ; 40.0\left(\mathrm{CH}_{2}\right) ; 37.2\left(\mathrm{CH}_{2}\right) ; 36.5(\mathrm{C}) ; 31.8(\mathrm{CH}) ; 31.4\left(\mathrm{CH}_{2}\right)$; $29.7\left(\mathrm{CH}_{2}\right) ; 25.6\left(\mathrm{CH}_{2}\right) ; 25.1\left(\mathrm{CH}_{3}, \mathrm{C} 21\right) ; 23.9\left(\mathrm{CH}_{2}\right) ; 22.4\left(\mathrm{CH}_{2}\right) ; 19.4\left(\mathrm{CH}_{3}, \mathrm{C} 19\right) ; 13.5$ $\left(\mathrm{CH}_{3}, \mathrm{C} 18\right)$. IR $u_{\max } 3433(\mathrm{O}-\mathrm{H}), 3323(\mathrm{~N}-\mathrm{H}), 3020(=\mathrm{C}-\mathrm{H}), 2923(-\mathrm{C}-\mathrm{H}), 1456 \mathrm{~cm}^{-1}$. HRMS calculated mass for $\mathrm{C}_{32} \mathrm{H}_{47} \mathrm{~N}_{4} \mathrm{O}_{2}\left(\mathrm{M}+\mathrm{H}^{+}\right) 519.3694$; found $\mathrm{m} / \mathrm{z} 519.3688$

4.2.9.12. Synthesis of ethyl 2-(4-(((R)-2-hydroxy-2-((3S,8S,9S,10R,13S,14S,17S)-3-hydroxy-10,13dimethyl-2,3,4,7,8,9,10,11,12,13,14,15,16,17-tetradecahydro-1H-cyclopenta[a]phenanthren-17yl)propyl)amino)methyl)-1H-1,2,3-triazol-1-yl)acetate (E2)

Following the general reaction conditions for CuAAC reaction, the reaction was worked up and purified to afford $60 \mathrm{mg}$ of a light-yellow solid (isolated yield: $90 \%) .{ }^{1} \mathrm{H}$ NMR $\left(300 \mathrm{MHz}, \mathrm{CDCl}_{3}\right) \delta 7.60(\mathrm{~s}, 1 \mathrm{H}$, $\left.\mathrm{C}_{\text {triazole }}-\mathrm{H}\right) ; 5.32(\mathrm{~s}, 1 \mathrm{H}, \mathrm{C} 6-\mathrm{H}) ; 5.11$ (s, 2H, N1 $\left.1_{\text {triazole }}-\mathrm{CH}_{2}\right) ; 4.24(\mathrm{q}, 2 \mathrm{H}, J=7.1 \mathrm{~Hz}$, $\left.\mathrm{C}(\mathrm{O}) \mathrm{OCH}_{2-}\right) ; 3.94\left(\mathrm{~s}, 2 \mathrm{H}, \mathrm{NH}-\mathrm{CH}_{2}\right.$-triazole); $3.49(\mathrm{~m}, 1 \mathrm{H}, \mathrm{C} 3-\mathrm{H}) ; 2.68-2.33(\mathrm{~m}, 6 \mathrm{H}) ; 2.23$ $(\mathrm{m}, 3 \mathrm{H}) ; 2.14-1.86(\mathrm{~m}, 4 \mathrm{H}) ; 1.79(\mathrm{~m}, 3 \mathrm{H}) ; 1.45(\mathrm{~m}, 10 \mathrm{H}) ; 1.25(\mathrm{~m}, 12 \mathrm{H}) ; 0.89(\mathrm{~m}, 12 \mathrm{H})$. ${ }^{13} \mathrm{C}$ NMR $\left(75 \mathrm{MHz}, \mathrm{CDCl}_{3}\right) \delta 166.3(\mathrm{C}=\mathrm{O}) ; 146.6$ (C, C5); $140.8\left(\mathrm{C}, \mathrm{C}_{\text {triazole }}\right) ; 123.6(\mathrm{CH}$, C6); $121.5(\mathrm{CH}, \mathrm{C} 5$ triazole $) ; 73.3(\mathrm{C}, \mathrm{C} 20) ; 71.7(\mathrm{CH}, \mathrm{C} 3) ; 62.4\left(\mathrm{CH}_{2}, \mathrm{O}-\mathrm{CH}_{2}\right) ; 58.7\left(\mathrm{CH}_{2}\right.$, C22); $56.6(\mathrm{CH}) ; 55.9(\mathrm{CH}) ; 50.9\left(\mathrm{~N}_{\text {triazole }}-\mathrm{CH}_{2}\right) ; 50.0(\mathrm{CH}) ; 42.3\left(\mathrm{CH}_{2}\right) ; 42.0(\mathrm{C}) ; 41.1$ 
$\left(\mathrm{CH}_{2}\right) ; 39.3\left(\mathrm{CH}_{2}\right) ; 37.2\left(\mathrm{CH}_{2}\right) ; 36.5(\mathrm{C}) ; 31.8\left(\mathrm{CH}_{2}\right) ; 31.7\left(\mathrm{CH}_{2}\right) ; 31.6(\mathrm{CH}) ; 27.1\left(\mathrm{CH}_{2}\right) ; 25.7$ $\left(\mathrm{CH}_{3}\right) ; 24.2\left(\mathrm{CH}_{2}\right) ; 20.9\left(\mathrm{CH}_{2}\right) ; 19.4\left(\mathrm{CH}_{3}\right) ; 14.1\left(\mathrm{CH}_{3}, \mathrm{O}-\mathrm{CH}_{2}-\mathrm{CH}_{3}\right) ; 13.2\left(\mathrm{CH}_{3}\right)$. IR u $\max 3446$ $(\mathrm{O}-\mathrm{H}), 3351(\mathrm{~N}-\mathrm{H}) 2924(-\mathrm{C}-\mathrm{H}), 2851(-\mathrm{C}-\mathrm{H}), 1749(\mathrm{C}=\mathrm{O}), 1465 \mathrm{~cm}^{-1}$. HRMS calculated mass for $\mathrm{C}_{29} \mathrm{H}_{47} \mathrm{~N}_{4} \mathrm{O}_{4}\left(\mathrm{M}+\mathrm{H}^{+}\right)$515.3592; found $\mathrm{m} / \mathrm{z} 515.3595$.

4.2.9.13. Synthesis of $(3 \mathrm{~S}, 8 \mathrm{~S}, 9 \mathrm{~S}, 10 \mathrm{R}, 13 \mathrm{~S}, 14 \mathrm{~S}, 17 \mathrm{~S})-17-((R)-2$-hydroxy-1-((1-octyl-1H-1,2,3-triazol4-yl)methyl)amino)propan-2-yl)-10,13-dimethyl-2,3,4,7,8,9,10,11,12,13,14,15,16,17-tetradecahydro1H-cyclopenta[a]phenanthren-3-ol (E3)

Following the general reaction conditions for CuAAC reaction, the reaction was worked up and purified to afford $60 \mathrm{mg}$ of a light-yellow solid (isolated yield: $85 \%) .{ }^{1} \mathrm{H}$ NMR $\left(300 \mathrm{MHz}, \mathrm{CDCl}_{3}\right) \delta 7.58(\mathrm{~s}, 1 \mathrm{H}$, $\mathrm{C}_{\text {triazole- }} \mathrm{H}$ ); $5.33(\mathrm{~d}, 1 \mathrm{H}, \mathrm{J}=4.9 \mathrm{~Hz}, \mathrm{C} 6-\mathrm{H}) ; 4.33$ (t, 2H, J = $7.2 \mathrm{~Hz}, \mathrm{~N} 1$ triazole-CH $\left.2_{2}\right) ; 4.04$ (s, 2H, NH-CH -triazole); $3.50(\mathrm{~m}, 1 \mathrm{H}, \mathrm{C} 3-\mathrm{H}) ; 2.72(\mathrm{~d}, 1 \mathrm{H}, J=12.2 \mathrm{~Hz}, \mathrm{C} 22-\mathrm{H}) ; 2.62(\mathrm{~d}, 1 \mathrm{H}$, $J=12.2 \mathrm{~Hz}, \mathrm{C} 22-\mathrm{H}) ; 2.26(\mathrm{~m}, 2 \mathrm{H}) ; 2.00-1.70(\mathrm{~m}, 8 \mathrm{H}) ; 1.71-1.37(\mathrm{~m}, 9 \mathrm{H}) ; 1.28(\mathrm{~m}, 14 \mathrm{H})$; 1.20 - $1.03(\mathrm{~m}, 3 \mathrm{H}) ; 0.99(\mathrm{~m}, 6 \mathrm{H}) ; 0.86(\mathrm{~m}, 7 \mathrm{H}) .{ }^{13} \mathrm{C} \mathrm{NMR}\left(75 \mathrm{MHz}, \mathrm{CDCl}_{3}\right) \delta 144.1$ (C, C5); 140.8 (C, C4triazole); $122.5(\mathrm{CH}, \mathrm{C} 6) ; 121.5\left(\mathrm{CH}, \mathrm{C}_{\text {triazole }}\right) ; 73.0$ (C, C20); 71.7 (CH, C3); 57.9 $(\mathrm{CH}) ; 57.7\left(\mathrm{CH}_{2}, \mathrm{C} 22\right) ; 56.9(\mathrm{CH}) ; 50.5\left(\mathrm{CH}_{2}, \mathrm{~N} 1_{\text {triazole }}-\mathrm{CH}_{2}\right) ; 50.0(\mathrm{CH}) ; 44.3\left(\mathrm{CH}_{2}\right) ; 42.7(\mathrm{C})$; $42.2\left(\mathrm{CH}_{2}\right) ; 40.0\left(\mathrm{CH}_{2}\right) ; 37.2\left(\mathrm{CH}_{2}\right) ; 36.5(\mathrm{C}) ; 31.7(\mathrm{CH}) ; 31.6\left(\mathrm{CH}_{2}\right) ; 31.3\left(\mathrm{CH}_{2}\right) ; 30.3\left(\mathrm{CH}_{2}\right)$; $29.1\left(\mathrm{CH}_{2}\right) ; 29.0\left(\mathrm{CH}_{2}\right) ; 29.0\left(\mathrm{CH}_{2}\right) ; 26.5\left(\mathrm{CH}_{2}\right) ; 24.8\left(\mathrm{CH}_{3}\right) ; 23.8\left(\mathrm{CH}_{2}\right) ; 22.6\left(\mathrm{CH}_{2}\right) ; 22.4$ $\left(\mathrm{CH}_{2}\right) ; 20.9\left(\mathrm{CH}_{2}\right) ; 19.4\left(\mathrm{CH}_{3}\right) ; 14.1\left(\mathrm{CH}_{3}\right.$, heptyl- $\left.\mathrm{CH}_{3}\right) ; 13.5\left(\mathrm{CH}_{2}, \mathrm{C} 18\right)$. IR u $\max 3431(\mathrm{O}-\mathrm{H})$, $3388(\mathrm{~N}-\mathrm{H}), 2927(-\mathrm{C}-\mathrm{H}), 2856(-\mathrm{C}-\mathrm{H}), 1456 \mathrm{~cm}^{-1}$. HRMS calculated mass for $\mathrm{C}_{33} \mathrm{H}_{57} \mathrm{~N}_{4} \mathrm{O}_{2}$ $\left(\mathrm{M}+\mathrm{H}^{+}\right)$541.4476; found $\mathrm{m} / \mathrm{z} 541.4476$.

4.2.9.14. Synthesis of $(3 S, 8 S, 9 S, 10 R, 13 S, 14 S, 17 S)-17-((R)-1-(((1-((E)-3,7-d i m e t h y l o c t a-2,6-d i e n-1-$ yl)-1H-1,2,3-triazol-4-yl)methyl)amino)-2-hydroxypropan-2-yl)-10,13-dimethyl-

\section{2,3,4,7,8,9,10,11,12,13,14,15,16,17-tetradecahydro-1H-cyclopenta[a]phenanthren-3-ol (E4)}

Following the general reaction conditions for CuAAC reaction, the reaction was worked up and purified to afford $59 \mathrm{mg}$ of a light-yellow solid (isolated yield: 81\%). ${ }^{1} \mathrm{H}$ NMR $\left(300 \mathrm{MHz}, \mathrm{CDCl}_{3}\right) \delta 7.49$ (bs, $1 \mathrm{H}, \mathrm{C} 5_{\text {triazole }}-\mathrm{H}$ ); 5.40 (t, J=7.4 Hz, 1H, CH=C); 5.32 (d, 1H, J = 3.9 Hz, C6-H); $5.14-4.99$ $(\mathrm{m}, 1 \mathrm{H}, \mathrm{CH}=\mathrm{C}) ; 4.93\left(\mathrm{t}, 2 \mathrm{H}, J=7.0 \mathrm{~Hz}, \mathrm{~N} 1_{\text {triazole }}-\mathrm{CH}_{2}\right) ; 3.98\left(\mathrm{~s}, 2 \mathrm{H}, \mathrm{NH}-\mathrm{CH}_{2}\right.$-triazole); 3.50 $(\mathrm{m}, 3 \mathrm{H}, \mathrm{C} 3-\mathrm{H}) ; 2.78-2.43(\mathrm{~m}, 2 \mathrm{H}, \mathrm{C} 4-\mathrm{H}) ; 2.37-1.89(\mathrm{~m}, 10 \mathrm{H}) ; 1.78(\mathrm{~m}, 6 \mathrm{H}) ; 1.73-1.31$ (m, 16H); $1.24(\mathrm{~s}, 7 \mathrm{H}) ; 1.02-0.70(\mathrm{~m}, 9 \mathrm{H}) .{ }^{13} \mathrm{C}$ NMR (75 MHz, CDCl 3$) \delta 143.4$ (C, C4triazole); $143.2(\mathrm{C}, \mathrm{C}=\mathrm{CH}) ; 140.8(\mathrm{C}, \mathrm{C} 5) ; 132.1(\mathrm{C}, \mathrm{C}=\mathrm{CH}) ; 123.4(\mathrm{CH}, \mathrm{C}=\mathrm{CH}) ; 123.2(\mathrm{CH}, \mathrm{C}=\mathrm{CH})$; $121.5(\mathrm{CH}, \mathrm{C} 6) ; 117.7\left(\mathrm{CH}, \mathrm{C} 5_{\text {triazolez }}\right) ; 116.9\left(\mathrm{CH}, \mathrm{C} 5_{\text {triazole }}\right) ; 71.7(\mathrm{CH}, \mathrm{C} 3) ; 58.2\left(\mathrm{CH}_{2}\right.$, C22); $57.7(\mathrm{CH}) ; 56.9(\mathrm{CH}) ; 50.0(\mathrm{CH}) ; 48.0\left(\mathrm{~N} 1\right.$ triazole $\left.^{-} \mathrm{CH}_{2}\right) ; 44.6\left(\mathrm{CH}_{2}\right) ; 42.7\left(\mathrm{CH}_{2}\right) ; 42.2$ (C); $40.0\left(\mathrm{CH}_{2}\right) ; 39.4\left(\mathrm{CH}_{2}\right) ; 37.2\left(\mathrm{CH}_{2}\right) ; 36.5(\mathrm{C}) ; 32.1\left(\mathrm{CH}_{2}\right) ; 31.8(\mathrm{CH}) ; 31.6\left(\mathrm{CH}_{2}\right) ; 31.4$ $\left(\mathrm{CH}_{2}\right) ; 26.3\left(\mathrm{CH}_{2}\right) ; 26.1 ; 25.7\left(\mathrm{CH}_{3}\right) ; 25.5\left(\mathrm{CH}_{3}\right) ; 24.9\left(\mathrm{CH}_{3}\right) ; 23.9\left(\mathrm{CH}_{2}\right) ; 23.4\left(\mathrm{CH}_{2}\right) ; 22.4$ $\left(\mathrm{CH}_{2}\right) ; 20.9\left(\mathrm{CH}_{2}\right) ; 19.4\left(\mathrm{CH}_{3}\right) ; 17.7\left(\mathrm{CH}_{3}\right) ; 16.5\left(\mathrm{CH}_{3}\right) ; 13.5\left(\mathrm{CH}_{3}\right)$. IR $u_{\max } 3300(\mathrm{O}-\mathrm{H}), 2998$ $(=\mathrm{C}-\mathrm{H}), 2884(-\mathrm{C}-\mathrm{H}), 1646,1444 \mathrm{~cm}^{-1}$. HRMS calculated mass for $\mathrm{C}_{35} \mathrm{H}_{57} \mathrm{~N}_{4} \mathrm{O}_{2}\left(\mathrm{M}+\mathrm{H}^{+}\right)$ 565.4476; found $\mathrm{m} / \mathrm{z} 565.4477$. 
4.2.9.15. Synthesis of $(3 \mathrm{~S}, 8 \mathrm{~S}, 9 \mathrm{~S}, 10 \mathrm{R}, 13 \mathrm{~S}, 14 \mathrm{~S}, 17 \mathrm{~S})-17-((R)-2-h y d r o x y-1-(((1-$ (3-phenylpropyl)-1H1,2,3-triazol-4-yl)methyl)amino)propan-2-yl)-10,13-dimethyl-2,3,4,7,8,9,10,11,12,13,14,15,16,17tetradecahydro-1H-cyclopenta[a]phenanthren-3-ol (E5)

Following the general reaction conditions for CuAAC reaction, the reaction was worked up and purified to afford $50 \mathrm{mg}$ of a light-yellow solid (isolated yield: $71 \%) .{ }^{1} \mathrm{H}$ NMR $\left(300 \mathrm{MHz}, \mathrm{CDCl}_{3}\right) \delta 7.46(\mathrm{~s}, 1 \mathrm{H}$, C5 triazole-H); $7.36-7.08(\mathrm{~m}, 5 \mathrm{H}$, aromatics); $5.34(\mathrm{~d}, 1 \mathrm{H}, \mathrm{J}=5.0 \mathrm{~Hz}, \mathrm{C} 6-\mathrm{H}) ; 4.34(\mathrm{t}, 2 \mathrm{H}, \mathrm{J}=$ $7.1 \mathrm{~Hz}, \mathrm{~N} 1_{\text {triazole }}-\mathrm{CH}_{2}$ ); 3.95 (s, 2H, NH-CH -triazole); 3.50 (d, $\left.1 \mathrm{H}, J=5.6 \mathrm{~Hz}, \mathrm{C} 6-\mathrm{H}\right) ; 3.28$ (m, 1H); 2.65 (t, 2H, J = $7.5 \mathrm{~Hz}, \mathrm{CH}_{2}$-phenyl); $2.57(\mathrm{~m}, 2 \mathrm{H}) ; 2.41-2.14(\mathrm{~m}, 5 \mathrm{H}) ; 1.96$ (s, 7H); 1.89 - $1.73(\mathrm{~m}, 4 \mathrm{H}) ; 1.73-1.31(\mathrm{~m}, 10 \mathrm{H}) ; 1.23(\mathrm{~s}, 4 \mathrm{H}) ; 1.13(\mathrm{~m}, 5 \mathrm{H}) ; 0.99(\mathrm{~s}, 6 \mathrm{H})$; 0.83 (s, 4H). ${ }^{13} \mathrm{C}$ NMR (75 MHz, $\left.\mathrm{CDCl}_{3}\right) \delta 146.7$ (C, C4triazole); 140.9 (C, C5); 140.2 (C, ipsoaromatic); 128.6 ( $\mathrm{CH}, m$-aromatic); 128.4 (CH, o-aromatic); $126.3(\mathrm{CH}, \mathrm{p}$-aromatic); 121.7 $(\mathrm{CH}, \mathrm{C} 6) ; 121.4\left(\mathrm{CH}, \mathrm{C}_{\text {triazole }}\right) ; 73.3(\mathrm{C}, \mathrm{C} 20) ; 71.6(\mathrm{CH}, \mathrm{C} 3) ; 56.4(\mathrm{CH}) ; 56.0(\mathrm{CH}) ; 50.0$ $\left(\mathrm{CH}_{2}\right) ; 49.5\left(\mathrm{CH}_{2}, \mathrm{CH}_{2}\right.$-phenyl); $42.3\left(\mathrm{CH}_{2}\right) ; 42.1(\mathrm{C}) ; 41.6\left(\mathrm{CH}_{2}\right) ; 40.0\left(\mathrm{CH}_{2}\right) ; 37.2\left(\mathrm{CH}_{2}\right)$; $36.5(\mathrm{C}) ; 32.5\left(\mathrm{CH}_{2}, \mathrm{~N} 1\right.$ triazole $\left.-\mathrm{CH}_{2}\right) ; 31.8\left(\mathrm{CH}_{2}\right) ; 31.8\left(\mathrm{CH}_{2}\right) ; 31.7\left(\mathrm{CH}_{2}\right) ; 26.7\left(\mathrm{CH}_{2}\right) ; 25.5$ $\left(\mathrm{CH}_{3}\right) ; 24.1\left(\mathrm{CH}_{2}\right) ; 21.1\left(\mathrm{CH}_{2}\right) ; 19.4\left(\mathrm{CH}_{3}\right) ; 18.8\left(\mathrm{CH}_{3}\right) ; 13.7\left(\mathrm{CH}_{2}\right)$. IR $v_{\max } 3452(\mathrm{O}-\mathrm{H}), 3314$ $(\mathrm{N}-\mathrm{H}) 2862(-\mathrm{C}-\mathrm{H}), 1451 \mathrm{~cm}^{-1}$. HRMS calculated mass for $\mathrm{C}_{34} \mathrm{H}_{51} \mathrm{~N}_{4} \mathrm{O}_{2}\left(\mathrm{M}+\mathrm{H}^{+}\right) 547.4007$; found $\mathrm{m} / \mathrm{z} 547.4007$.

4.2.9.16. Synthesis of $(3 \mathrm{~S}, 8 \mathrm{~S}, 9 \mathrm{~S}, 10 \mathrm{R}, 13 \mathrm{~S}, 14 \mathrm{~S}, 17 \mathrm{~S})-17-((R)-2$-hydroxy-1-(4-phenyl-1H-1,2,3-triazol1-yl)propan-2-yl)-10,13-dimethyl-2,3,4,7,8,9,10,11,12,13,14,15,16,17-tetradecahydro-1Hcyclopenta[a]phenanthren-3-ol (F1)

Following the general reaction conditions for CuAAC reaction, the reaction was worked up and purified to afford $46 \mathrm{mg}$ of a white solid (isolated yield: $69 \%) .{ }^{1} \mathrm{H}$ NMR $\left(300 \mathrm{MHz}, \mathrm{CDCl}_{3}\right) \delta 7.90(\mathrm{~s}, 1 \mathrm{H}$, C5 triazole-H); 7.85 (d, 2H, J=7.7 Hz, o-aromatic); 7.43 (t, 2H, J = 7.5 Hz, m-aromatic); 7.33 (t, $1 \mathrm{H}, J=7.4 \mathrm{~Hz}, p$-aromatic); $5.36(\mathrm{~d}, 1 \mathrm{H}, J=5.1 \mathrm{~Hz}, \mathrm{C} 6-\mathrm{H}) ; 4.34(\mathrm{~d}, 2 \mathrm{H}, J=4.6 \mathrm{~Hz}, \mathrm{C} 22-$ $\mathrm{H}) ; 3.52(\mathrm{~m}, 1 \mathrm{H}, \mathrm{C} 3-\mathrm{H}) ; 2.29(\mathrm{~m}, 2 \mathrm{H}, \mathrm{C} 4-\mathrm{H}) ; 2.18-1.65(\mathrm{~m}, 9 \mathrm{H}) ; 1.65-1.38(\mathrm{~m}, 10 \mathrm{H}) ; 1.22$ $(\mathrm{m}, 6 \mathrm{H}) ; 0.97(\mathrm{~m}, 9 \mathrm{H}) .{ }^{13} \mathrm{C}$ NMR $\left(75 \mathrm{MHz}, \mathrm{CDCl}_{3}\right) \delta 147.4$ (C, C4 $\left.4_{\text {triazole }}\right) ; 140.8$ (C, C5); 130.3 (C, ipso-aromatic); $128.8(\mathrm{CH}, m$-aromatic); $128.2(\mathrm{CH}, o$-aromatic); 125.5 (CH, paromatic); $122.0\left(\mathrm{CH}, \mathrm{C}_{\text {triazole }}\right) ; 121.3(\mathrm{CH}, \mathrm{C} 6) ; 74.2(\mathrm{C}, \mathrm{C} 20) ; 71.1(\mathrm{CH}, \mathrm{C} 3) ; 60.2\left(\mathrm{CH}_{2}\right.$, C22); $57.5(\mathrm{CH}) ; 56.7(\mathrm{CH}) ; 49.9(\mathrm{CH}) ; 43.0(\mathrm{C}) ; 41.7\left(\mathrm{CH}_{2}\right) ; 40.0\left(\mathrm{CH}_{2}\right) ; 37.2\left(\mathrm{CH}_{2}\right) ; 36.4$ (C); $31.6\left(\mathrm{CH}_{2}\right) ; 31.6\left(\mathrm{CH}_{2}\right) ; 31.3\left(\mathrm{CH}_{2}\right) ; 23.8\left(\mathrm{CH}_{2}\right) ; 23.4\left(\mathrm{CH}_{3}, \mathrm{C} 21\right) ; 22.2\left(\mathrm{CH}_{2}\right) ; 20.8$ $\left(\mathrm{CH}_{2}\right) ; 19.1\left(\mathrm{CH}_{3}, \mathrm{C} 19\right) ; 13.2\left(\mathrm{CH}_{3}, \mathrm{C} 18\right) . \mathrm{IR} \mathrm{U}_{\max } 3489(\mathrm{O}-\mathrm{H}), 3050(=\mathrm{C}-\mathrm{H}), 2933(-\mathrm{C}-\mathrm{H})$, $1457 \mathrm{~cm}^{-1}$. HRMS calculated mass for $\mathrm{C}_{30} \mathrm{H}_{41} \mathrm{~N}_{3} \mathrm{O}_{2} \mathrm{Na}\left(\mathrm{M}+\mathrm{Na}^{+}\right)$498.3091; found $\mathrm{m} / \mathrm{z}$ 498.3068.

4.2.9.17. Synthesis of methyl 1-((R)-2-hydroxy-2-((3S,8S,9S,10R,13S,14S,17S)-3-hydroxy-10,13dimethyl-2,3,4,7,8,9,10,11,12,13,14,15,16,17-tetradecahydro-1H-cyclopenta[a]phenanthren-17yl)propyl)-1H-1,2,3-triazole-4-carboxylate (F2) 
Following the general reaction conditions for CUAAC reaction, the reaction was worked up and purified to afford $47 \mathrm{mg}$ of a white solid (isolated yield: 73\%). ${ }^{1} \mathrm{H}$ NMR $\left(300 \mathrm{MHz}, \mathrm{CDCl}_{3}\right) \delta 8.24(\mathrm{~s}, 1 \mathrm{H}$, $\mathrm{C}_{\text {triazole-H) }}$; 5.36 (d, 1H, J = 5.1 Hz, C6-H); $4.49-4.17(\mathrm{~m}, 2 \mathrm{H}, \mathrm{C} 22-\mathrm{H}) ; 3.95$ (s, 3H, O$\left.\mathrm{CH}_{3}\right) ; 3.53(\mathrm{~s}, 1 \mathrm{H}, \mathrm{C} 3-\mathrm{H}) ; 2.29(\mathrm{~m}, 2 \mathrm{H}, \mathrm{C} 4-\mathrm{H}) ; 2.16-1.63(\mathrm{~m}, 9 \mathrm{H}) ; 1.63-1.37(\mathrm{~m}, 13 \mathrm{H})$; $1.25(\mathrm{~s}, 3 \mathrm{H}) ; 1.18-0.71(\mathrm{~m}, 12 \mathrm{H}) .{ }^{13} \mathrm{C} \operatorname{NMR}\left(75 \mathrm{MHz} \mathrm{CDCl}_{3}\right) \delta 161.3(\mathrm{C}=\mathrm{O}), 140.8(\mathrm{C}$, C5), 139.7 (C=O), 129.3 (C, C4 triazole $_{\text {) }} 121.4$ ( ( 5 triazole $_{\text {) }} 74.7$ (C, C20), 71.7 ( $\left.\mathrm{CH}, \mathrm{C} 3\right), 59.9$ $\left(\mathrm{CH}_{3}, \mathrm{O}-\mathrm{CH}_{3}\right), 57.4(\mathrm{CH}), 56.6(\mathrm{CH}), 52.2\left(\mathrm{CH}_{2}\right), 49.9(\mathrm{CH}), 43.2(\mathrm{C}), 42.2\left(\mathrm{CH}_{2}\right), 40.0$ $\left(\mathrm{CH}_{2}\right), 37.2\left(\mathrm{CH}_{2}\right), 36.5(\mathrm{C}), 31.7\left(\mathrm{CH}_{2}\right), 31.6\left(\mathrm{CH}_{2}\right), 31.3(\mathrm{CH}), 24.5\left(\mathrm{CH}_{3}, \mathrm{C} 21\right), 23.9\left(\mathrm{CH}_{2}\right)$, $22.3\left(\mathrm{CH}_{2}\right), 20.8\left(\mathrm{CH}_{2}\right), 19.4\left(\mathrm{CH}_{3}, \mathrm{C} 19\right), 13.6\left(\mathrm{CH}_{3}, \mathrm{C} 18\right) . \mathrm{IR} \mathrm{u}_{\max } 3468(\mathrm{O}-\mathrm{H}), 3048(=\mathrm{C}-\mathrm{H})$, $2933(-\mathrm{C}-\mathrm{H}) ; 1740(\mathrm{C}=\mathrm{O}) ; 1476 \mathrm{~cm}^{-1}$. HRMS calculated mass for $\mathrm{C}_{26} \mathrm{H}_{39} \mathrm{~N}_{3} \mathrm{O}_{4} \mathrm{Na}\left(\mathrm{M}+\mathrm{Na}^{+}\right)$ 480.2833; found $\mathrm{m} / \mathrm{z} 480.2821$.

4.2.9.18. Synthesis of $(3 \mathrm{~S}, 8 \mathrm{~S}, 9 \mathrm{~S}, 10 \mathrm{R}, 13 \mathrm{~S}, 14 \mathrm{~S}, 17 \mathrm{~S})-17-((R)-2-h y d r o x y-1-(4-p e n t y l-1 \mathrm{H}-1,2,3$-triazol1-yl)propan-2-yl)-10,13-dimethyl-2,3,4,7,8,9,10,11,12,13,14,15,16,17-tetradecahydro-1Hcyclopenta[a]phenanthren-3-ol (F3)

Following the general reaction conditions for CuAAC reaction, the reaction was worked up and purified to afford $54 \mathrm{mg}$ of a white solid (isolated yield: $86 \%) .{ }^{1} \mathrm{H}$ NMR $\left(300 \mathrm{MHz}, \mathrm{CDCl}_{3}\right) \delta 7.37(\mathrm{~s}, 1 \mathrm{H}$, $\mathrm{C}_{\text {triazole }} \mathrm{H}$ ); $5.33(\mathrm{~d}, 1 \mathrm{H}, J=5.0 \mathrm{~Hz}, \mathrm{C} 6-\mathrm{H}) ; 4.23(\mathrm{~s}, 2 \mathrm{H}, \mathrm{C} 22-\mathrm{H}) ; 3.51(\mathrm{dt}, 1 \mathrm{H}, J=11.3,6.0$ $\mathrm{Hz}, \mathrm{C} 3) ; 2.69$ (t, 2H, J = 7.7 Hz, C4triazole- $\left.\mathrm{CH}_{2^{-}}\right) ; 2.36-2.04(\mathrm{~m}, 4 \mathrm{H}) ; 2.04-1.74(\mathrm{~m}, 7 \mathrm{H})$; $1.68(\mathrm{p}, J=7.9 \mathrm{~Hz}, 4 \mathrm{H}) ; 1.50(\mathrm{~d}, J=5.5 \mathrm{~Hz}, 6 \mathrm{H}) ; 1.40-1.16(\mathrm{~m}, 6 \mathrm{H}) ; 1.16-0.77(\mathrm{~m}, 16 \mathrm{H})$.

${ }^{13} \mathrm{C}$ NMR (75 MHz, $\left.\mathrm{CDCl}_{3}\right) \delta 148.1$ (C, C4triazole); 140.8 (C, C5); $122.5\left(\mathrm{CH}, \mathrm{C}_{\text {triazole }}\right) ; 121.4$ $(\mathrm{CH}, \mathrm{C} 6) ; 74.7(\mathrm{C}, \mathrm{C} 20) ; 71.6(\mathrm{CH}, \mathrm{C} 3) ; 59.8\left(\mathrm{CH}_{2}, \mathrm{C} 22\right) ; 57.4(\mathrm{CH}) ; 56.7(\mathrm{CH}) ; 49.9(\mathrm{CH})$; $43.2(\mathrm{C}) ; 42.2\left(\mathrm{CH}_{2}\right) ; 40.0\left(\mathrm{CH}_{2}\right) ; 37.2\left(\mathrm{CH}_{2}\right) ; 36.5(\mathrm{C}) ; 31.7\left(\mathrm{CH}_{2}\right) ; 31.6\left(\mathrm{CH}_{2}\right) ; 31.4\left(\mathrm{CH}_{2}\right)$; $31.3\left(\mathrm{CH}_{2}\right) ; 29.1\left(\mathrm{CH}_{2}\right) ; 25.6\left(\mathrm{CH}_{2}\right) ; 24.5\left(\mathrm{CH}_{3}, \mathrm{C} 21\right) ; 23.9\left(\mathrm{CH}_{2}\right) ; 22.4\left(\mathrm{CH}_{2}\right) ; 22.3\left(\mathrm{CH}_{2}\right)$; $20.9\left(\mathrm{CH}_{2}\right) ; 19.4\left(\mathrm{CH}_{3}, \mathrm{C} 19\right) ; 14.0\left(\mathrm{CH}_{3}\right.$, heptyl- $\left.\mathrm{CH}_{3}\right) ; 13.5\left(\mathrm{CH}_{3}, \mathrm{C} 18\right)$. IR $u_{\max } 3447(\mathrm{O}-\mathrm{H})$, $3058(=\mathrm{C}-\mathrm{H}), 2932(-\mathrm{C}-\mathrm{H}), 1486 \mathrm{~cm}^{-1}$. HRMS calculated mass for $\mathrm{C}_{29} \mathrm{H}_{48} \mathrm{~N}_{3} \mathrm{O}_{2}\left(\mathrm{M}+\mathrm{H}^{+}\right)$ 470.3741 ; found $\mathrm{m} / \mathrm{z} 470.3736$.

4.2.9.19. Synthesis of $(3 \mathrm{~S}, 8 \mathrm{~S}, 9 \mathrm{~S}, 10 \mathrm{R}, 13 \mathrm{~S}, 14 \mathrm{~S}, 17 \mathrm{~S})-17-((R)-2$-hydroxy-1-(4-(2-hydroxyethyl)-1H1,2,3-triazol-1-yl)propan-2-yl)-10,13-dimethyl-2,3,4,7,8,9,10,11,12,13,14,15,16,17-tetradecahydro-1Hcyclopenta[a]phenanthren-3-ol (F4)

Following the general reaction conditions for CuAAC reaction, the reaction was worked up and purified to afford $61 \mathrm{mg}$ of a white solid (isolated yield: $97 \%) .{ }^{1} \mathrm{H}$ NMR $\left(300 \mathrm{MHz}, \mathrm{CDCl}_{3}\right) \delta 7.50(\mathrm{~s}, 1 \mathrm{H}$, $\mathrm{C}_{\text {triazole }} \mathrm{H}$ ); 5.35 (d, 1H, J = 5.3 Hz, C6-H); 4.27 (s, 2H, C22-H); $3.96(\mathrm{t}, 2 \mathrm{H}, J=5.8 \mathrm{~Hz}$, $\left.\mathrm{CH}_{2}-\mathrm{OH}\right) ; 3.54(\mathrm{~m}, 1 \mathrm{H}, \mathrm{C} 3-\mathrm{H}) ; 2.96\left(\mathrm{t}, 2 \mathrm{H}, \mathrm{J}=5.8 \mathrm{~Hz}, \mathrm{C} 4\right.$ triazole $\left.-\mathrm{CH}_{2}\right) ; 2.47-2.00(\mathrm{~m}, 6 \mathrm{H})$; $1.84(\mathrm{~m}, 10 \mathrm{H}) ; 1.52(\mathrm{~m}, 15 \mathrm{H}) ; 1.07(\mathrm{~m}, 13 \mathrm{H}) ; 0.90(\mathrm{~s}, 3 \mathrm{H}, \mathrm{C} 18-\mathrm{H}) .{ }^{13} \mathrm{C} \mathrm{NMR}(75 \mathrm{MHz}$, $\left.\mathrm{CDCl}_{3}\right) \delta 140.8$ ppm (C, C4 triazole $_{\text {) }}$; 140.8 (C, C5); $123.5\left(\mathrm{CH}, \mathrm{CH}_{\text {triazole }}\right) ; 121.5(\mathrm{CH}, \mathrm{C} 6) ; 74.7$ (C, C20); $71.7(\mathrm{CH}, \mathrm{C} 3) ; 61.7\left(\mathrm{CH}_{2}, \mathrm{CH}_{2}-\mathrm{OH}\right) ; 59.8\left(\mathrm{CH}_{2}, \mathrm{C} 22\right) ; 57.3(\mathrm{CH}) ; 56.7(\mathrm{CH}) ; 49.9$ $(\mathrm{CH}) ; 43.2(\mathrm{C}) ; 42.2\left(\mathrm{CH}_{2}\right) ; 40.0\left(\mathrm{CH}_{2}\right) ; 37.2\left(\mathrm{CH}_{2}\right) ; 36.5(\mathrm{C}) ; 31.7\left(\mathrm{CH}_{2}\right) ; 31.6\left(\mathrm{CH}_{2}\right) ; 31.3$ 
$\left(\mathrm{CH}_{2}\right) ; 28.6\left(\mathrm{CH}_{2}, \mathrm{C} 4\right.$ triazole $\left.-\mathrm{CH}_{2}\right) 24.5\left(\mathrm{CH}_{3}, \mathrm{C} 21\right) ; 23.9\left(\mathrm{CH}_{2}\right) ; 22.3\left(\mathrm{CH}_{2}\right) ; 20.9\left(\mathrm{CH}_{2}\right) ; 19.4$ $\left(\mathrm{CH}_{3}, \mathrm{C} 19\right)$; $13.6\left(\mathrm{CH}_{3}, \mathrm{C} 18\right)$. IR $\mathrm{v}_{\max } 3421(\mathrm{O}-\mathrm{H}), 3028(=\mathrm{C}-\mathrm{H}), 2932(-\mathrm{C}-\mathrm{H}), 1454 \mathrm{~cm}^{-1}$. HRMS calculated mass for $\mathrm{C}_{26} \mathrm{H}_{41} \mathrm{~N}_{3} \mathrm{O}_{3} \mathrm{Na}\left(\mathrm{M}+\mathrm{Na}^{+}\right)$466.3040; found $\mathrm{m} / \mathrm{z}$ 466.2996.

4.2.9.20. Synthesis of $(3 S, 8 S, 9 S, 10 R, 13 S, 14 S, 17 S)-17-((R)-2-h y d r o x y-1-(4-(3-p h e n y l p r o p y l)-1 H-$ 1,2,3-triazol-1-yl)propan-2-yl)-10,13-dimethyl-2,3,4,7,8,9,10,11,12,13,14,15,16,17-tetradecahydro-1Hcyclopenta[a]phenanthren-3-ol (F5)

Following the general procedure for CUAAC reaction, the reaction was worked up and purified to afford $67 \mathrm{mg}$ of a white solid (isolated yield: $92 \%)$. ${ }^{1} \mathrm{H}$ NMR $\left(300 \mathrm{MHz}, \mathrm{CDCl}_{3}\right) \delta 7.37(\mathrm{~s}, 1 \mathrm{H}$, C5triazole$\mathrm{H}) ; 7.32-7.22$ (m, 2H, m-aromatic); 7.17 (m, 3H, o- and p-aromatic); $5.34(\mathrm{~d}, 1 \mathrm{H}, J=5.0$ $\mathrm{Hz}, \mathrm{C} 6-\mathrm{H}$ ); 4.23 (s, 2H, NH-CH2-triazol); 3.51 (dt, 1H, J = 11.5, $6.0 \mathrm{~Hz}, \mathrm{C} 3-\mathrm{H}) ; 2.74$ (t, 2H, J $\left.=7.7 \mathrm{~Hz}, \mathrm{~N} 1_{\text {triazole }}-\mathrm{CH}_{2}\right) ; 2.67\left(\mathrm{t}, 2 \mathrm{H}, J=7.7 \mathrm{~Hz}, \mathrm{CH}_{2}-\right.$ phenyl); $2.35-2.17$ (m, 2H, C4-H); $2.03(\mathrm{~m}, 6 \mathrm{H}) ; 1.89-1.60(\mathrm{~m}, 7 \mathrm{H}) ; 1.50(\mathrm{~s}, 6 \mathrm{H}) ; 1.25(\mathrm{~m}, 3 \mathrm{H}) ; 1.11(\mathrm{~s}, 3 \mathrm{H}) ; 1.00(\mathrm{~m}, 6 \mathrm{H})$; 0.88 (s, 3H, C18-H). ${ }^{13} \mathrm{C}$ NMR $\left(75 \mathrm{MHz} \mathrm{CDCl}_{3}\right) \delta 147.5$ (C, C4 $\left.4_{\text {triazole }}\right) ; 141.9$ (C, ipsoaromatic), 140.8 (C, C5); $128.5(\mathrm{CH}, m$-aromatic); $128.3(\mathrm{CH}, o$-aromatic) $125.8(\mathrm{CH}, p$ aromatic); $122.7\left(\mathrm{CH}, \mathrm{C}_{\text {triazole }}\right) ; 121.4(\mathrm{CH}, \mathrm{C} 6) ; 74.7(\mathrm{C}, \mathrm{C} 20) ; 71.6(\mathrm{CH}, \mathrm{C} 3) ; 59.8\left(\mathrm{CH}_{2}\right.$, C22); $57.3(\mathrm{CH}) ; 56.8(\mathrm{CH}) ; 49.9(\mathrm{CH}) ; 43.2(\mathrm{C}) ; 42.2\left(\mathrm{CH}_{2}\right) ; 40.0\left(\mathrm{CH}_{2}\right) ; 37.2\left(\mathrm{CH}_{2}\right) ; 36.5$ (C); $35.3\left(\mathrm{CH}_{2}\right) ; 31.7\left(\mathrm{CH}_{2}\right) ; 31.6\left(\mathrm{CH}_{2}\right) ; 31.3\left(\mathrm{CH}_{2}\right) ; 31.1\left(\mathrm{CH}_{2}\right) ; 25.2\left(\mathrm{CH}_{2}\right) ; 24.5\left(\mathrm{CH}_{3}\right.$, C21); $23.9\left(\mathrm{CH}_{2}\right) ; 22.3\left(\mathrm{CH}_{2}\right) ; 20.9\left(\mathrm{CH}_{2}\right) ; 19.4\left(\mathrm{CH}_{3}, \mathrm{C} 19\right) ; 13.2\left(\mathrm{CH}_{3}, \mathrm{C} 18\right)$. IR umax 3347 (O-H), $3040(=\mathrm{C}-\mathrm{H}), 2922(-\mathrm{C}-\mathrm{H}), 1458 \mathrm{~cm}^{-1}$. HRMS calculated mass for $\mathrm{C}_{33} \mathrm{H}_{47} \mathrm{~N}_{3} \mathrm{O}_{2} \mathrm{Na}$ $\left(\mathrm{M}+\mathrm{Na}^{+}\right) 540.3561$; found $\mathrm{m} / \mathrm{z} 540.3533$.

\subsection{In vitro activity against $L$. donovani $\left(\mathrm{IC}_{50}\right)$}

Antileishmanial activity of the compounds was tested in vitro on a culture of Leishmania donovani promastigotes (strain S1). Compounds with appropriate dilution were added to a 96 well microplate with promastigotes $\left(2 \times 10^{6} \mathrm{cell} / \mathrm{mL}\right)$ reaching final concentrations of 40,8 and $1.6 \mu \mathrm{g} / \mathrm{mL}$. The plates were incubated at $26^{\circ} \mathrm{C}$ for $72 \mathrm{~h}$ and growth was determined by Alamar blue assay [32]. Pentamidine and Amphotericin B were used as standard antileishmanial agents.

\subsection{In vitro activity against $T$. brucei $\left(\mathrm{IC}_{50}\right)$}

T. brucei BSF parasites were seeded at $1 \times 10^{3}$ parasites $/ \mathrm{ml}$ in $200 \mu \mathrm{L}$ growth medium containing different concentrations of triazolylsterols. After incubation at $37^{\circ} \mathrm{C}$ for 3 days, $20 \mu \mathrm{L}$ Alamar blue (Biosource UK Ltd) was added to each well and the plates incubated for a further 16 hours. The fluorescence of each culture was determined as described above and the $\mathrm{IC}_{50}$ value for each compound established.

\subsection{In vitro activity against $T$. cruzi $\left(\mathrm{IC}_{50}\right)$}

T. cruzi epimastigotes were seeded at $5 \times 10^{5}$ parasites $/ \mathrm{ml}$ in $200 \mu \mathrm{L}$ growth medium containing different concentrations of triazolylsterols and $20 \mu \mathrm{L}$ Alamar blue ${ }^{\mathrm{TM}}$ (Biosource UK Ltd) was added to each well. 
After incubation at $27^{\circ} \mathrm{C}$ for 14 days, the cell densities were determined by monitoring the fluorescence of each culture using a Gemini Fluorescent Plate reader (Molecular Devices) at an excitation wavelength of $530 \mathrm{~nm}$, emission wavelength of $585 \mathrm{~nm}$ and a filter cut off at $550 \mathrm{~nm}$, and the $\mathrm{IC}_{50}$ established. The colour change resulting from the reduction of Alamar blue is proportional to the number of live cells, which was established following production of a standard curve.

\subsection{Vero Cell activities}

The in vitro cytotoxicity was determined against mammalian kidney fibroblasts (VERO). The assay was performed in 96-well tissue culture-treated plates as described earlier. Briefly, cells were seeded to the wells of the plate $(25,000$ cells/well) and incubated for $24 \mathrm{~h}$. Samples were added and plates were again incubated for $48 \mathrm{~h}$. The number of viable cells was counted and the plot for $\mathrm{EC}_{50}$ performed.

\subsection{Physicochemical properties prediction}

SMILES of compounds A1 - F5 were pasted on the Osiris DataWarrior platform [26], and relevant properties were predicted (Total Molweight, cLogP, cLogS, H-Acceptors, H-Donors, Total Surface Area, Relative PSA, Polar Surface Area, Druglikeness, Mutagenic, Tumorigenic, Reproductive Effective, Irritant). $\log \mathrm{D}_{7.4}$ was also predicted, using the online ChemAxon LogD predictor [27].

\subsection{ADMETox predictions}

Computational modelling to estimate the bioavailability, aqueous solubility, human intestinal absorption, metabolism, mutagenicity, toxicity, etc. for the compounds was performed using the SwissADME [28] and pkCSM [29] platforms.

SwissADME: The SMILES of compounds A1 - F5 were uploaded to SwissADME (http://www.swissadme.ch/), pasting the list of smiles on the designated window. The following parameters were calculated: Physicochemical Properties (Formula, MW, Num. heavy atoms, Num. arom. heavy atoms, Fraction Csp3, Num. rotatable bonds, Num. $\mathrm{H}$-bond acceptors, Num. H-bond donors, Molar Refractivity and TPSA); Lipophilicity (Log Po/w (iLOGP), Log Po/w (XLOGP3), Log Po/w (WLOGP), Log Po/w (MLOGP), Log Po/w (SILICOS-IT) and Consensus Log Po/w); Water Solubility (Log S (ESOL), Solubility, Class, Log S (Ali), Solubility, Class, Log S (SILICOS-IT), Solubility and Class); Pharmacokinetics (GI absorption, BBB permeant, P-gp substrate, CYP1A2 inhibitor, CYP2C19 inhibitor, CYP2C9 inhibitor, CYP2D6 inhibitor, CYP3A4 inhibitor and Log Kp - 
skin permeation-); Druglikeness (Lipinski, Ghose, Veber, Egan, Muegge and Bioavailability Score); Medicinal Chemistry (PAINS, Brenk, Lead likeness and Synthetic accessibility).

pkCSM: The SMILES of compounds A1 - F5 were uploaded to pkCSM (http://biosig.unimelb.edu.au/pkcsm/prediction), through $a^{*}$.txt SMILE file. The following parameters were calculated: Absorption (Water solubility, Caco2 permeability, Intestinal absorption (human), Skin Permeability, P-glycoprotein substrate, P-glycoprotein I inhibitor, P-glycoprotein II inhibitor); Distribution (VDss (human), Fraction unbound (human), BBB permeability, CNS permeability); Metabolism (CYP2D6 substrate, CYP3A4 substrate, CYP1A2 inhibitior, CYP2C19 inhibitior, CYP2C9 inhibitior, CYP2D6 inhibitior, CYP3A4 inhibitior); Excretion (Total Clearance, Renal OCT2 substrate); Toxicity (AMES toxicity, Max. tolerated dose (human), hERG I inhibitor, hERG II inhibitor, Oral Rat Acute Toxicity (LD50), Oral Rat Chronic Toxicity (LOAEL), Hepatotoxicity, Skin Sensitisation, T.Pyriformis toxicity, Minnow toxicity).

\section{Acknowledgements}

This work was supported in part by grants from the National Research Council of Argentina, CONICET (2012-14/0448 awarded to G.R.L.); Agencia Nacional de Promoción Científica y Tecnológica, ANPCyT-Argentina (PICT 2017/0396 awarded to G.R.L.); Universidad Nacional de Rosario (80020190300101UR) and Fundación Josefina Prats. The research leading to these results has, in part, received funding from the UK Research and Innovation via the Global Challenges Research Fund under grant agreement A Global Network for Neglected Tropical Diseases grant number MR/P027989/1. G.R.L. is a member of the scientific staff of CONICET-Argentina. E.O.J.P. and M.S.B. thanks CONICET for the award of a fellowship.

\section{References}

[1] World Health Organization, (n.d.). http://www.who.int.

[2] V. Pillay-van Wyk, D. Bradshaw, Mortality and socioeconomic status: the vicious cycle between poverty and ill health, Lancet Glob. Heal. 5 (2017) e851-e852.

https://doi.org/10.1016/S2214-109X(17)30304-2.

[3] D.H. Molyneux, L. Savioli, D. Engels, Neglected tropical diseases: progress towards addressing the chronic pandemic, Lancet. 389 (2017) 312-325.

https://doi.org/10.1016/S0140-6736(16)30171-4. 
[4] R.G.A. Feachem, I. Chen, O. Akbari, A. Bertozzi-Villa, S. Bhatt, F. Binka, M.F. Boni, C. Buckee, J. Dieleman, A. Dondorp, A. Eapen, N. Sekhri Feachem, S. Filler, P. Gething, R. Gosling, A. Haakenstad, K. Harvard, A. Hatefi, D. Jamison, K.E. Jones, C. Karema, R.N. Kamwi, A. Lal, E. Larson, M. Lees, N.F. Lobo, A.E. Micah, B. Moonen, G. Newby, X. Ning, M. Pate, M. Quiñones, M. Roh, B. Rolfe, D. Shanks, B. Singh, K. Staley, J. Tulloch, J. Wegbreit, H.J. Woo, W. Mpanju-Shumbusho, Malaria eradication within a generation: ambitious, achievable, and necessary, Lancet. 394 (2019) 1056-1112. https://doi.org/10.1016/S0140-6736(19)31139-0.

[5] S. Aksoy, P. Buscher, M. Lehane, P. Solano, J. Van Den Abbeele, Human African trypanosomiasis control: Achievements and challenges, PLoS Negl. Trop. Dis. 11 (2017) e0005454. https://doi.org/10.1371/journal.pntd.0005454.

[6] W. Zhang, P. Lypaczewski, G. Matlashewski, Optimized CRISPR-Cas9 Genome Editing for Leishmania and Its Use To Target a Multigene Family, Induce Chromosomal Translocation, and Study DNA Break Repair Mechanisms, MSphere. 2 (2017) e00340-16. https://doi.org/10.1128/mSphere.00340-16.

[7] J. Jannin, P. Solano, I. Quick, P. Debre, The francophone network on neglected tropical diseases, PLoS Negl. Trop. Dis. 11 (2017) e0005738. https://doi.org/10.1371/journal.pntd.0005738.

[8] T. Beneke, R. Madden, L. Makin, J. Valli, J. Sunter, E. Gluenz, A CRISPR Cas9 highthroughput genome editing toolkit for kinetoplastids, R. Soc. Open Sci. 4 (2017) 170095. https://doi.org/10.1098/rsos.170095.

[9] A.J. Saviola, F. Negrão, J.R. Yates III, Proteomics of Select Neglected Tropical Diseases, Annu. Rev. Anal. Chem. 13 (2020) 315-336. https://doi.org/10.1146/annurev-anchem091619-093003.

[10] J.F. Osorio-Méndez, A.M. Cevallos, Discovery and genetic validation of chemotherapeutic targets for Chagas' disease, Front. Cell. Infect. Microbiol. 8 (2019) 439. https://doi.org/10.3389/fcimb.2018.00439.

[11] J.A. Urbina, Lipid biosynthesis pathways as chemotherapeutic targets in kinetoplastid parasites, Parasitology. 114 (1997) S91-S99. https://doi.org/10.1017/S0031182097001194.

[12] L. Urán Landaburu, A.J. Berenstein, S. Videla, P. Maru, D. Shanmugam, A. Chernomoretz, F. Agüero, TDR Targets 6: Driving drug discovery for human pathogens through intensive chemogenomic data integration, Nucleic Acids Res. 48 (2020) D992-D1005. https://doi.org/10.1093/nar/gkz999.

[13] F. Gigante, M. Kaiser, R. Brun, I.H. Gilbert, SAR studies on azasterols as potential anti- 
trypanosomal and anti-leishmanial agents, Bioorganic Med. Chem. 17 (2009) 5950-5961. https://doi.org/10.1016/j.bmc.2009.06.062.

[14] L. Gros, S.O. Lorente, C. Jimenez, V. Yardley, L. Rattray, H. Wharton, S. Little, S.L. Croft, L.M. Ruiz-Perez, D. Gonzalez-Pacanowska, I.H. Gilbert, Evaluation of azasterols as antiparasitics, J. Med. Chem. 49 (2006) 6094-6103. https://doi.org/10.1021/jm060290f.

[15] F. Magaraci, C. Jimenez Jimenez, C. Rodrigues, J.C.F. Rodrigues, M. Vianna Braga, V. Yardley, K. De Luca-Fradley, S.L. Croft, W. De Souza, L.M. Ruiz-Perez, J. Urbina, D. Gonzalez Pacanowska, I.H. Gilbert, Azasterols as Inhibitors of Sterol 24-Methyltransferase in Leishmania Species and Trypanosoma cruzi, J. Med. Chem. 46 (2003) 4714-4727. https://doi.org/10.1021/jm021114j.

[16] E.O.J. Porta, P.B. Carvalho, M.A. Avery, B.L. Tekwani, G.R. Labadie, Click chemistry decoration of amino sterols as promising strategy to developed new leishmanicidal drugs, Steroids. 79 (2014) 28-36. https://doi.org/10.1016/j.steroids.2013.10.010.

[17] W.D. Nes, Sterol methyl transferase: enzymology and inhibition, Biochim. Biophys. Acta. 1529 (2000) 63-88. https://doi.org/10.1016/s1388-1981(00)00138-4.

[18] W.D. Nes, Enzyme redesign and interactions of substrate analogues with sterol methyltransferase to understand phytosterol diversity, reaction mechanism and the nature of the active site, Biochem. Soc. Trans. 33 (2005) 1189-1196. https://doi.org/10.1042/BST20051189.

[19] C. Jiménez-Jiménez, J. Carrero-Lérida, M. Sealey-Cardona, L.M. Ruiz Pérez, J.A. Urbina, D. González Pacanowska, $\Delta 24(25)$-sterol methenyltransferase: Intracellular localization and azasterol sensitivity in Leishmania major promastigotes overexpressing the enzyme, Mol. Biochem. Parasitol. 160 (2008) 52-59. https://doi.org/10.1016/j.molbiopara.2008.03.010.

[20] E.O.J. Porta, M.M. Vallejos, A.B.J. Bracca, G.R. Labadie, Experimental and theoretical studies of the [3,3]-sigmatropic rearrangement of prenyl azides, RSC Adv. 7 (2017) 4752747538. https://doi.org/10.1039/c7ra09759j.

[21] E.O.J. Porta, S.N. Jäger, I. Nocito, G.I. Lepesheva, E.C. Serra, B.L. Tekwani, G.R. Labadie, Antitrypanosomal and antileishmanial activity of prenyl-1,2,3-triazoles, Medchemcomm. 8 (2017) 1015-1021. https://doi.org/10.1039/c7md00008a.

[22] D.T. Fox, C.D. Poulter, Synthesis and evaluation of 1-deoxy-D-xylulose 5-phosphoric acid analogues as alternate substrates for methylerythritol phosphate synthase, J. Org. Chem. 70 (2005) 1978-1985. https://doi.org/10.1021/jo048022h.

[23] J.S. Li, Y. Li, C. Son, A.M.H. Brodie, Synthesis and evaluation of pregnane derivatives as inhibitors of human testicular 17a-hydroxylase/C17,20-lyase, J. Med. Chem. 39 (1996) 
4335-4339. https://doi.org/10.1021/jm960245f.

[24] Y. Takeuchi, Y. Makino, K. Maruyama, E. Yoshii, A new 2-pyrone synthesis and its application to butadienolide synthesis, Heterocycles. 14 (1980) 163-168.

https://doi.org/10.3987/R-1980-02-0163.

[25] M. Egido-Gabás, P. Serrano, J. Casas, A. Llebaria, A. Delgado, New aminocyclitols as modulators of glucosylceramide metabolism, Org. Biomol. Chem. 3 (2005) 1195-1201. https://doi.org/10.1039/b411473f.

[26] T. Sander, J. Freyss, M. Von Korff, C. Rufener, DataWarrior: An open-source program for chemistry aware data visualization and analysis, J. Chem. Inf. Model. 55 (2015) 460-473. https://doi.org/10.1021/ci500588j.

[27] ChemAxon Calculator and Predictors, (n.d.). https://chemaxon.com/ products/calculatorsand-predictors.

[28] A. Daina, O. Michielin, V. Zoete, SwissADME: A free web tool to evaluate pharmacokinetics, drug-likeness and medicinal chemistry friendliness of small molecules, Sci. Rep. 7 (2017) 42717. https://doi.org/10.1038/srep42717.

[29] D.E.V. Pires, T.L. Blundell, D.B. Ascher, pkCSM: Predicting small-molecule pharmacokinetic and toxicity properties using graph-based signatures, J. Med. Chem. 58 (2015) 4066-4072. https://doi.org/10.1021/acs.jmedchem.5b00104.

[30] L. Di, H. Rong, B. Feng, Demystifying Brain Penetration in Central Nervous System Drug Discovery, J. Med. Chem. 56 (2013) 2-12. https://doi.org/10.1021/jm301297f.

[31] Z. Szendi, P. Forgó, F. Sweet, Complete1H and 13C NMR spectra of pregnenolone, Steroids. 60 (1995) 442-446. https://doi.org/10.1016/0039-128x(94)00047-g.

[32] J. Mikus, D. Steverding, A simple colorimetric method to screen drug cytotoxicity against Leishmania using the dye Alamar Blue ${ }^{\circledR}$, Parasitol. Int. 48 (2000) 265-269. https://doi.org/10.1016/S1383-5769(99)00020-3. 